\title{
Control of Parallel Hippocampal Output Pathways by Amygdalar Long-Range Inhibition.
}

Rawan AISubaie ${ }^{1}$, Ryan W S Wee ${ }^{1}$, Anne Ritoux ${ }^{1}$, Karyna Mischanchuk ${ }^{1}$, Daniel Regester ${ }^{1}$ and Andrew F MacAskill ${ }^{1 \star}$

${ }^{1}$ Department of Neuroscience, Physiology and Pharmacology, University College London, Gower St, London, WC1E 6BT

${ }^{*}$ Corresponding author: a.macaskill@ucl.ac.uk

\section{ABSTRACT}

Projections from the basal amygdala $(\mathrm{BA})$ to the ventral hippocampus $(\mathrm{vH})$ are proposed to provide information about the rewarding or threatening nature of learned associations to support appropriate goal-directed and anxiety-like behaviour. Such behaviour occurs via the differential activity of multiple, parallel populations of pyramidal neurons in $\mathrm{vH}$ that project to distinct downstream targets, but the nature of BA input and how it connects with these populations is unclear. Using channelrhodopsin-2-assisted circuit mapping in mice, we show that $\mathrm{BA}$ input to $\mathrm{vH}$ consists of both excitatory and inhibitory projections. Excitatory input specifically targets BAand nucleus accumbens-projecting $\mathrm{vH}$ neurons, and avoids prefrontal cortex-projecting $\mathrm{vH}$ neurons; while inhibitory input preferentially targets BA-projecting neurons. Through this specific connectivity, BA inhibitory projections gate place-value associations by controlling the activity of nucleus accumbens-projecting $\mathrm{vH}$ neurons. Our results define a parallel excitatory and inhibitory projection from BA to $\mathrm{vH}$ that can support goaldirected behaviour.

\section{INTRODUCTION}

The hippocampus is key for episodic memory, learning and spatial navigation, as well as motivation, affect and anxiety (Gray and McNaughton, 2003; O'Keefe and Nadel, 1978; Strange et al., 2014; Wikenheiser and Schoenbaum, 2016). At almost every level of investigation - from gene expression, to afferent and efferent connectivity, and behavioural function - the hippocampus is organised as a gradient along is dorsal to ventral (posterior to anterior in humans) axis (Fanselow and Dong, 2010; Strange et al., 2014). Within this axis the most dorsal portion is proposed to be involved in learning and utilising fine-grained spatial and temporal structure, whereas the most ventral pole is thought to be involved in affect and motivation, and has a key role in value based and reward driven decision making and anxiety-like calculations (Fanselow and Dong, 2010; Strange et al., 2014).

A distinguishing factor that separates the ventral from the dorsal hippocampus is dense input from the corticobasolateral nuclear complex of the amygdala (basal amygdala, BA; McDonald and Mott, 2016; Strange et al., 2014). The BA is comprised of a diverse set of nuclei including the basolateral amygdala (BLA), the basomedial amygdala (BMA), the medial amygdala (MEA) and cortical amygdala, each of which sends projections to vH (McDonald and Mott, 2016; Petrovich et al., 2001; Strange et al., 2014). These nuclei, and their projections to $\mathrm{vH}$ are thought to be crucial for the learning of reward and threat associated cues, and for the generation of appropriate goal-directed and anxiety-like behaviour (Beyeler et al., 2018, 2016; Felix-Ortiz et al., 2013; Felix-Ortiz and Tye, 2014; Hitchcott and Phillips, 1997; McHugh et al., 2004; Pi et al., 2020; Richardson 
bioRxiv preprint doi: https://doi.org/10.1101/2021.03.08.434367; this version posted March 8, 2021. The copyright holder for this preprint (which was not certified by peer review) is the author/funder, who has granted bioRxiv a license to display the preprint in perpetuity. It is made available under aCC-BY-NC-ND 4.0 International license.

et al., 2004; Selden et al., 1991; Sheth et al., 2008; Yang and Wang, 2017). Thus, it is commonly assumed that powerful and specific synaptic connectivity between these two structures is crucial for the maintenance of such behaviours. However, there is limited information describing the organisation of such functional connectivity between amygdala input and neurons in vH (Bazelot et al., 2015; Felix-Ortiz et al., 2013; Pi et al., 2020).

This lack of understanding is compounded by the fact that the ventral hippocampus, in particular its output structure the ventral CA1 and subiculum - where the majority of BA input is found - is organised as a parallel circuit, such that the majority of neurons project to only one downstream area (Gergues et al., 2020; Naber and Witter, 1998; Wee and MacAskill, 2020). Thus, while vH has powerful connections to the nucleus accumbens (NAc), the prefrontal cortex (PFC) and back to the BA, each of these projections arises from a distinct population of neurons. Importantly each of these projection populations is increasingly shown to underlie unique behavioural functions (Adhikari et al., 2010; Jimenez et al., 2018; LeGates et al., 2018; Sanchez-Bellot and MacAskill, 2020). For example, $\mathrm{vH}^{\mathrm{NAc}}$ neuron activity is high during motivated behaviour and around rewarded locations (Ciocchi et al., 2015; Okuyama et al., 2016; Reed et al., 2018), is necessary for place-value associations (LeGates et al., 2018; Trouche et al., 2019) and can promote spatial and instrumental reinforcement (Britt et al., 2012; LeGates et al., 2018). In contrast, vHPFC activity is proposed to support the resolution of approach avoidance conflict, and contribute to spatial working memory (Padilla-Coreano et al., 2016; SanchezBellot and MacAskill, 2020; Spellman et al., 2015), while $\mathrm{vH}^{\mathrm{BA}}$ activity is proposed to support contextual learning (Jimenez et al., 2018). However, it remains unclear how the activity of these distinct populations in $\mathrm{vH}$ is differentially controlled to promote these functions. We reasoned that a means for this control would be projection-specific innervation from BA.

The circuit organisation of the nuclei in the BA is similar to classic cortical circuitry - with the majority of neurons classed as either excitatory pyramidal neurons, or local inhibitory interneurons (McDonald and Mott, 2016). However, there is also evidence suggesting the presence of long-range inhibitory projection neurons throughout BA (Dedic et al., 2018; McDonald et al., 2012; McDonald and Zaric, 2015; Seo et al., 2016). Similar inhibitory projections from cortex are hypothesised to have a crucial regulatory role in modulating hippocampal circuit function (Basu et al., 2016; Melzer et al., 2012), but the connectivity and function of BA long range inhibitory input in $\mathrm{vH}$ has never been directly investigated.

In this study, we used a combination of retrograde tracing, electrophysiology and channelrhodopsin-2-assisted circuit mapping to show that BA provides both excitatory and direct inhibitory input to distinct projection populations within $\mathrm{vH}$. We show that excitatory projections uniquely target $\mathrm{vH}$ neurons that project to $\mathrm{NAc}$ and back to the BA, and do not connect with neurons that project to PFC. In contrast, long range inhibitory input preferentially targets $\mathrm{BA}$ projecting $\mathrm{vH}$ neurons. Next, using a simple network model constrained by our electrophysiology recordings, we predicted that the ability of BA input to drive motivation- and value-promoting $\mathrm{vH}$ projections to NAc was dependent on the coactivation of inhibitory input from BA. Finally, we confirmed these predictions using in vivo optogenetics and genetically targeted pharmacology to show that long range inhibition is required for the generation of spatial place preference. Together our results outline a novel inhibitory projection 
bioRxiv preprint doi: https://doi.org/10.1101/2021.03.08.434367; this version posted March 8, 2021. The copyright holder for this preprint (which was not certified by peer review) is the author/funder, who has granted bioRxiv a license to display the preprint in perpetuity. It is made available under aCC-BY-NC-ND 4.0 International license.

1 from amygdala to ventral hippocampus that defines the activity of $\mathrm{vH}$ output neurons, and is able to control 2 hippocampal output to promote the formation of spatial place preference. 


\section{RESULTS}

\section{BA input into ventral hippocampus is both excitatory and inhibitory.}

While the majority of investigation of BA-vH connectivity is focussed on projections specifically from the BLA, it is known that multiple BA nuclei project to $\mathrm{vH}$ (McDonald and Mott, 2016). Therefore, we first determined the spatial distribution of neurons in BA that send input into $\mathrm{vH}$ by injecting a fluorescently conjugated cholera toxin beta subunit $(C T X \beta)$ into the ventral part of the hippocampus (Figure $1 \mathrm{~A}$ ). CTX $\beta$ is taken up by presynaptic terminals at the injection site, and retrogradely transported to label the soma of afferent neurons. After two weeks, we serially sectioned labelled brains and mapped labelled cell locations to the Allen Brain atlas (Fürth et al., 2018; Wee and MacAskill, 2020). We found that neurons sending input to $\mathrm{vH}$ were widely dispersed throughout the entire BA, including in BLA, BMA, and MEA, as well as in more cortical amygdala areas (Figure 1B-D, McDonald and Mott, 2016; Strange et al., 2014). Overall, this experiment confirmed that there is large input from disperse $\mathrm{BA}$ nuclei to $\mathrm{vH}$, focussed around the posterior BMA and BLA.
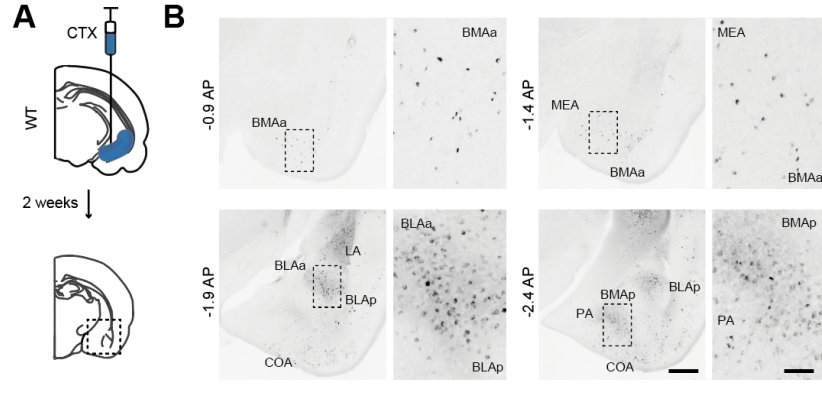

C

D
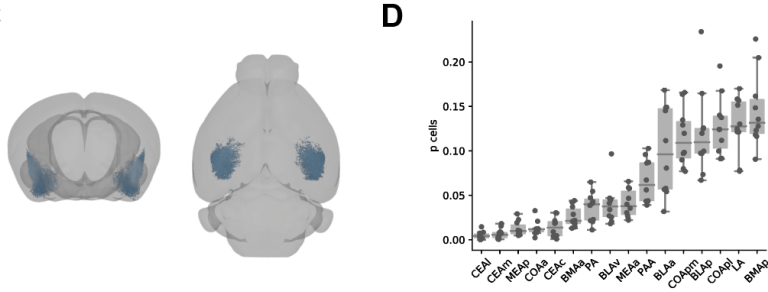

Figure 1 | Distribution of BA input to $\mathrm{vH}$.

A. Schematic of experiment. CTX $\beta$ was injected into $\mathrm{vH}, 2$ weeks later coronal slices of BA were examined for retrogradely labelled neurons.

B. Example slices showing widespread labelling throughout numerous BA nuclei. Scale bar = 500 um, 100 um (zoom).

C. Whole brain distribution of labelled BA neurons

D. Summary showing proportion of labelled BA cells in each nuclei.

Full size figures are reproduced at the end of the manuscript.

We next tested whether BA input to vH may be both excitatory and inhibitory (McDonald and Mott, 2016). We repeated our experiment using a vGAT::cre::dtomato reporter mouse. In this experiment, CTX $\beta$ labelled neurons in BA could be distinguished as either GABAergic (VGAT+), or putatively excitatory (VGAT-) based on fluorescence colocalization. Using this approach, we found that a small but consistent proportion of BA neurons that projected to $\mathrm{vH}$ were GABAergic (Figure 2A, Figure S1A, B). Using whole-brain registration as before, we found inhibitory projection neurons were intermingled with excitatory projection neurons, such that there was no obvious anatomical separation between inhibitory and classic excitatory projections. Supporting this, both were found in consistent proportions ( $\sim 5 \%$ of labelled neurons) throughout each nucleus in BA, and across all three anatomical axes (Figure S1A-C). Thus, in addition to the classically described excitatory projection from BA to $\mathrm{vH}$, there is a parallel inhibitory projection arising from GABAergic neurons from across the BA.

We next investigated if these projections made functional connections onto $\mathrm{vH}$ pyramidal neurons. To recruit both excitatory and inhibitory projections, we expressed ChR2 under a pan-neuronal synapsin promoter (hsynChR2) in the BA using an injection of adenoassociated virus (AAV) centred on posterior BMA and BLA. Two weeks later we prepared acute slices of $\mathrm{vH}$ from these animals and performed whole-cell recordings from 
A

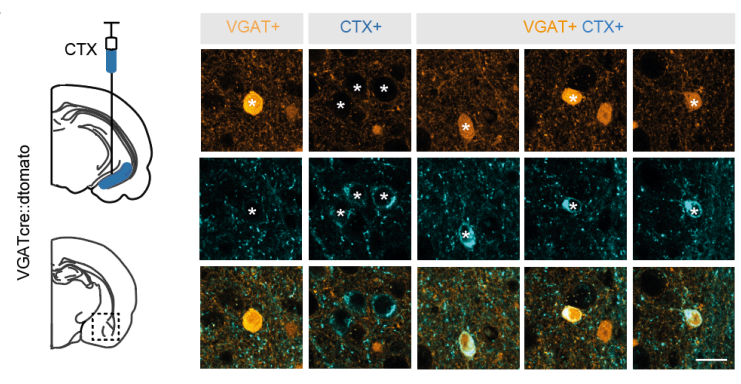

B

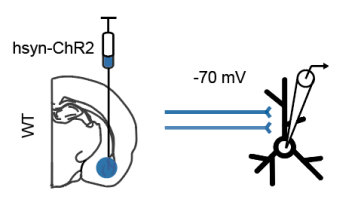

C
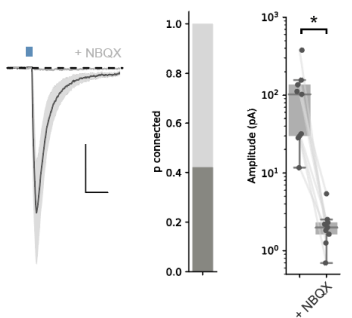

D
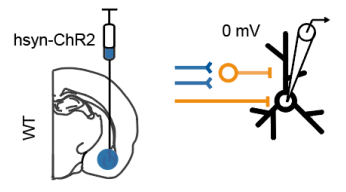

$\mathbf{F}$

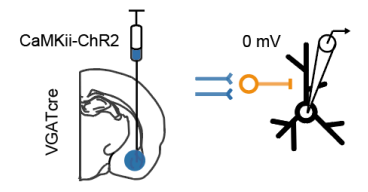

G
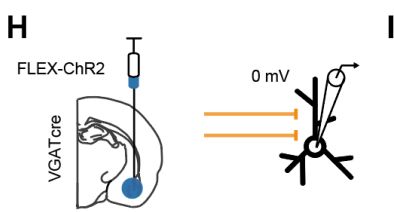

E
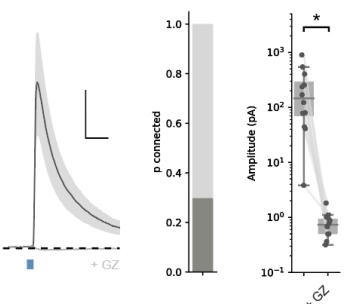

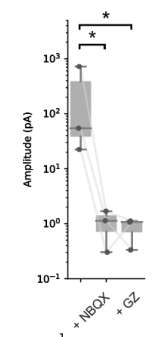

1

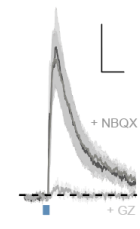

Figure 2 | BA input to $\mathrm{vH}$ is both excitatory and inhibitory.

A. CTX $\beta$ injection in $\mathrm{vH}$ in a vGAT::cre::dtomato mouse line reveals inhibitory neurons (VGAT+), putative excitatory neurons that project to $\mathrm{vH}(\mathrm{CTX}+)$ and inhibitory neurons that project to $\mathrm{vH}(\mathrm{vGAT}+$ $\mathrm{CTX}+$ ). Scale bar $=20 \mathrm{um}$.

B. Schematic showing experimental setup. ChR2 was expressed using the pan-neuronal synapsin promoter using an AAV injection in $B A$. After allowing for expression, whole cell recordings were performed in voltage clamp at $-70 \mathrm{mV}$ in $\mathrm{vH}$.

C. Brief pulses of blue light evoke excitatory currents that are blocked by the AMPA receptor antagonist NBQX. Left, Average current trace pre and post NBQX. Middle, proportion of recorded cells connected (with time-locked response to light). Right, Amplitude before and after NBQX. Note log scale. NBQX blocks excitatory currents evoked by BA input. Scale bar $=50 \mathrm{pA}, 10 \mathrm{~ms}$.

D, E. As B,C but for voltage clamp at $0 \mathrm{mV}$ before and after the GABA receptor antagonist gabazine. Gabazine blocks inhibitory currents evoked by BA input. Scale bar $=50 \mathrm{pA}, 10 \mathrm{~ms}$.

F. Feedforward inhibition isolated using ChR2 expression under the CaMKii promoter.

G. Brief pulses of blue light evoked inhibitory currents at $0 \mathrm{mV}$ that are blocked by the AMPA receptor antagonist NBQX. Left, Average current trace pre and post NBQX and GZ. Right, Amplitude before and after NBQX and GZ. Note log scale. NBQX blocks inhibitory currents evoked by CaMKii BA input, indicating it is solely feedforward. Scale bar $=50 \mathrm{pA}, 10 \mathrm{~ms}$.

H, I. As for F, G but direct inhibitory input isolated using ChR2 expression only in vGAT+BA neurons. NBQX has no effect on direct inhibitory connection, while it is blocked by GZ, indicating it is a direct, long range inhibitory connection. Scale bar $=15 \mathrm{pA}, 10 \mathrm{~ms}$.

pyramidal neurons in the axon-rich CA1/ proximal subiculum border (Figure 2B). Recording in voltage clamp at $-70 \mathrm{mV}$, we could isolate excitatory currents in response to blue light in $\sim 40 \%$ of recorded neurons that were blocked by bath application of the AMPA receptor antagonist NBQX (Figure $2 C)$. In the same neurons, we could also record inhibitory currents at $0 \mathrm{mV}$ in $\sim 30 \%$ of cells that were blocked by the - GABA receptor antagonist gabazine (Figure 2E). Thus, BA

input makes excitatory and inhibitory connections with $\mathrm{vH}$ pyramidal neurons via AMPA and GABA receptors.

Our retrograde tracing experiments (Figure 2A) suggested that in addition to classic feed-forward inhibition (where excitatory axons make connections with local interneurons to disynaptically inhibit pyramidal neurons), BA input also contained axons originating from inhibitory neurons, that would putatively make direct inhibitory connections. To confirm this possibility, we first used a pharmacological approach (Figure S1D-F). Using mice injected with hsyn-ChR2 in BA as above, we recorded inhibitory currents in $\mathrm{vH}$ pyramidal neurons at $0 \mathrm{mV}$. We first removed feedforward inhibition with bath application of the AMPA receptor antagonist NBQX. Interestingly, while inhibition was completely blocked in a subset of neurons $(8 / 12)$, in the remaining population inhibitory currents persisted. This finding suggests that - consistent with our retrograde anatomy - a proportion of this inhibitory input was due to a direct long range inhibitory projection from the BA. Consistent with this prediction, 
the remaining current was blocked by bath application of gabazine, indicating that it was a GABA receptor mediated current.

To test this more explicitly, we again used vGAT::cre mice where cre is expressed only in GABAergic neurons, and expressed ChR2 in BA using either a CaMKii promoter - to confine expression to only putative excitatory pyramidal neurons (Felix-Ortiz et al., 2013; Pi et al., 2020), or using a cre-dependent cassette to restrict ChR2 only to putative GABAergic neurons (Seo et al., 2016). Consistent with the presence of both excitatory and inhibitory projections, CaMKii+ BA input evoked strong inhibitory currents at $0 \mathrm{mV}$ (Figure 2G), but these currents were blocked by bath application of $N B Q X$, showing that the inhibitory currents were a result of solely feedforward inhibition. In contrast, vGAT+ BA input also showed robust input at $0 \mathrm{mV}$ (Figure 2I), but this inhibitory current was insensitive to NBQX application, but blocked by gabazine, suggesting a direct inhibitory connection.

Together, these experiments define a novel, direct inhibitory projection from $\mathrm{BA}$ to $\mathrm{vH}$. Thus, contrary to previous assumptions, BA provides two parallel projections to pyramidal neurons in $\mathrm{vH}$, one excitatory, and one inhibitory.

\section{BA excitatory and inhibitory input selectively connects with unique $\mathrm{vH}$ output populations}

The relatively sparse connectivity in our results above suggest that both excitatory and inhibitory BA input may connect with only a proportion of pyramidal neurons in $\mathrm{vH}$. The CA1/proximal subiculum border of $\mathrm{vH}$ is composed of multiple populations of neurons organised as parallel projections (Figure S2, Gergues et al., 2020; Naber and Witter, 1998; Wee and MacAskill, 2020). Therefore, we hypothesised that this low connectivity may be an indication that BA input connects differentially with neurons that project to either NAc, PFC or back to BA.

To investigate this possibility, we again injected ChR2 into BA, but also retrograde tracers into either BA and NAc, or BA and PFC. This allowed us, two weeks later, to prepare acute slices and obtain whole cell recordings from pairs of fluorescently-identified neurons in $\mathrm{vH}$ projecting to each downstream target. Paired recordings of neurons in the same slice and field of view allowed for a comparison of synaptic input while controlling for confounds such as injection volume, and the exact location in CA1/subiculum.

We first compared excitatory input in voltage clamp at $-70 \mathrm{mV}$, as before with pan-neuronal expression of ChR2 using the synapsin promoter. Sequential paired recordings of $\mathrm{vH}^{\mathrm{BA}}$ and $\mathrm{vH}^{\mathrm{NAc}}$ neurons showed that light-evoked excitatory BA input was on average equivalent onto both populations (Figure $3 A-C$ ). In contrast, paired recordings of $\mathrm{vH}^{\mathrm{BA}}$ and $\mathrm{vH}^{\mathrm{PFC}}$ neurons revealed an almost complete lack of excitatory input onto $\mathrm{vH}^{\mathrm{PFC}}$ neurons (Figure 3D-F).

We next investigated long range inhibitory input using vGAT::cre mice and expressing cre dependent ChR2 in BA. Paired recordings of $\mathrm{vH}^{\mathrm{BA}}$ and $\mathrm{vH}^{\mathrm{NAc}}$ neurons showed a marked bias of inhibitory input to $\mathrm{vH}^{\mathrm{BA}}$ neurons, with consistently smaller input onto neighbouring $\mathrm{vH}^{\mathrm{NAc}}$ neurons (Figure 3G-I). Similarly to excitatory input, pairs of $\mathrm{vH}^{\mathrm{BA}}$ and $\mathrm{vH}^{\mathrm{PFC}}$ projecting neurons showed essentially no connectivity from $\mathrm{BA}$ to $\mathrm{vH}^{\mathrm{PFC}}$ neurons (Figure $3 \mathrm{~J}-\mathrm{L}$ ). 


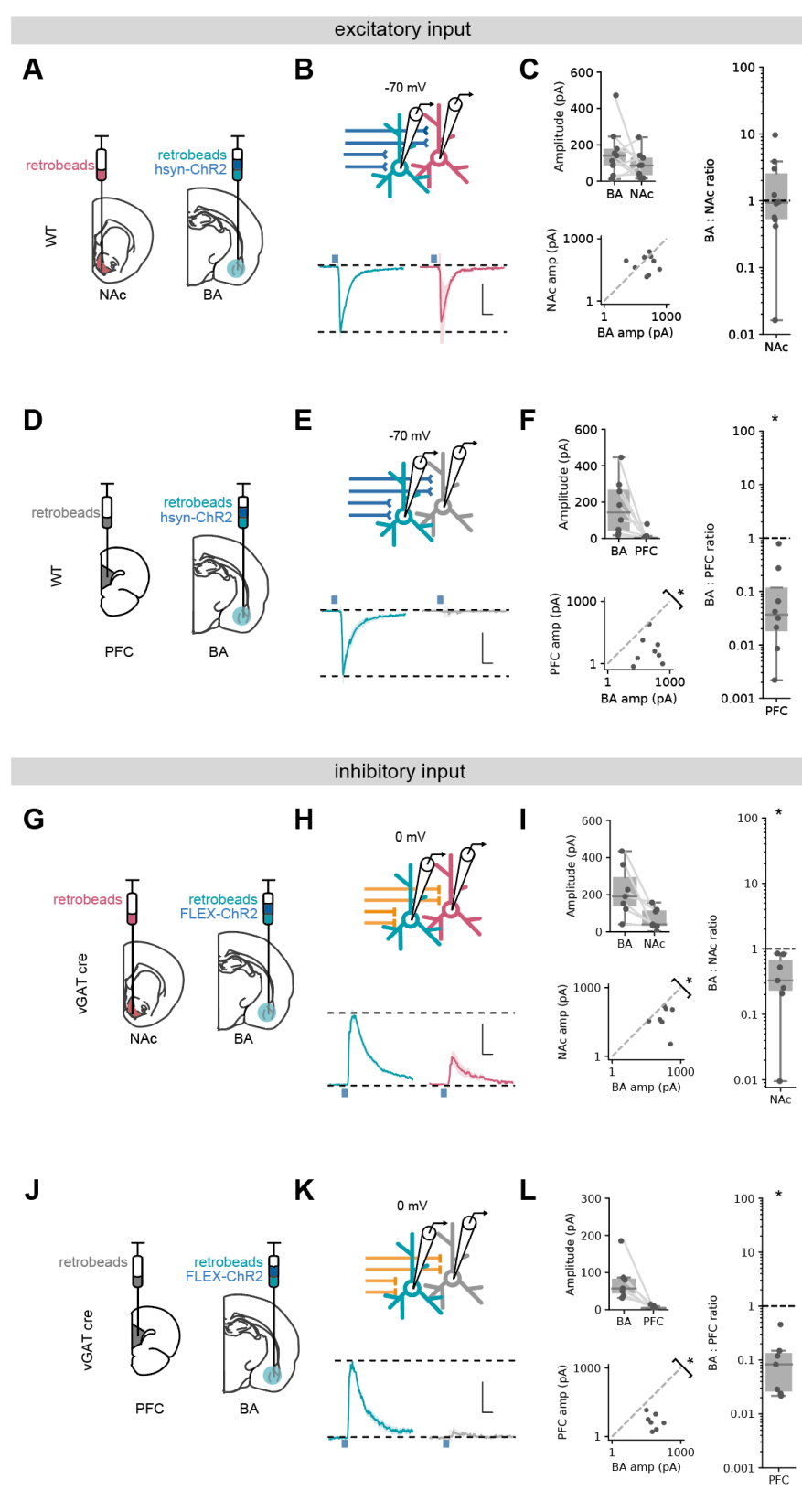

Figure 3 | Excitatory and inhibitory BA input differentially targets $\mathrm{vH}$ output populations.

\begin{abstract}
A. Schematic of experiment $\mathrm{vH}^{\mathrm{NAc}}$ and $\mathrm{vH}^{\mathrm{BA}}$ neurons were labelled with retrobead injections, and $\mathrm{ChR} 2$ was expressed pan neuronally in BA.

B. Paired, fluorescently targeted recordings from neurons in each pathway and recording of light evoked currents. Top, recording setup. Bottom, average light evoked currents in $\mathrm{vH}^{\mathrm{BA}}$ (green) and $\mathrm{vH}^{\mathrm{NAc}}(r e d)$ neurons. Scale bar $=0.5 \mathrm{vH}^{\mathrm{BA}}$ response, $10 \mathrm{~ms}$.
\end{abstract}

C. Summary of amplitude of light evoked BA input in pairs of $\mathrm{vH}^{\mathrm{NAc}}$ and $\mathrm{vH}^{\mathrm{BA}}$ neurons (top). When displayed as a scatter plot (bottom), or as the ratio of $\mathrm{vH}^{\mathrm{NAc}}$ : $\mathrm{vH}^{\mathrm{BA}}$ (right), the amplitudes cluster on the line of unity, indicating these population shave equal input. Note log axis.

D-F. As A-C but for pairs of $\mathrm{vH}^{\mathrm{BA}}$ and $\mathrm{vH}^{\mathrm{PFC}}$ neurons. Note when displayed as a scatter and a ratio of $\mathrm{vH}^{\mathrm{PFC}}: \mathrm{vH}^{\mathrm{BA}}$ amplitudes are below the line of unity, indicating input preferentially innervates $\mathrm{vH}^{\mathrm{BA}}$ neurons.

G-L. As A-F but for inhibitory input from BA isolated by expressing FLEX ChR2 in a vGAT::Cre line. Note when displayed as a scatter and a ratio, both $\mathrm{vH}^{\mathrm{PFC}}$ and $\mathrm{vH}^{\mathrm{NAc}}$ amplitudes are below the line of unity, indicating inhibitory input preferentially innervates $\mathrm{vH}^{\mathrm{BA}}$ neurons in both cases. Scale bar $=0.5 \mathrm{vH}^{\mathrm{BA}}$ response, $10 \mathrm{~ms}$.

Overall, these experiments suggest that excitatory input from BA equally targets $\mathrm{vH}$ neurons projecting to either NAc or BA, but not with those projecting to PFC. In contrast, inhibitory input from BA preferentially targets $\mathrm{vH}$ neurons projecting to $\mathrm{BA}$, has a weak connection to those that project to NAc, and again avoids those projecting to PFC. Together, this shows that both excitatory and inhibitory BA input to $\mathrm{vH}$ have unique and distinct connectivity patterns with $\mathrm{vH}$ output circuitry, and suggests it is

well placed to define their differential activity.

\section{$B A$ excitatory and inhibitory input interact with local inhibitory circuitry in $\mathrm{vH}$}

We next wanted to understand how BA input may interact with the local $\mathrm{vH}$ circuit to define activity of the different output populations. $\mathrm{vH}$ output populations have been shown to be strongly connected with local interneurons to form both feedforward and feedback inhibitory circuitry, and this connectivity can vary on a cell-type specific basis (S.-H. Lee et al., 2014; Soltesz and Losonczy, 2018). Thus we next wanted to ask 3 questions about the layout of the $\mathrm{vH}$ circuit, and how it is influenced by BA input: (1) Does excitatory and inhibitory BA input connect directly with local interneurons in $\mathrm{vH}$ ? (2) Do pyramidal neurons from each projection population connect with local interneurons to provide feedback inhibition? (3) Are there differences in how local interneurons connect with pyramidal neurons from different projection populations? 
bioRxiv preprint doi: https://doi.org/10.1101/2021.03.08.434367; this version posted March 8, 2021. The copyright holder for this preprint (which was not certified by peer review) is the author/funder, who has granted bioRxiv a license to display the preprint in perpetuity. It is made available under aCC-BY-NC-ND 4.0 International license.
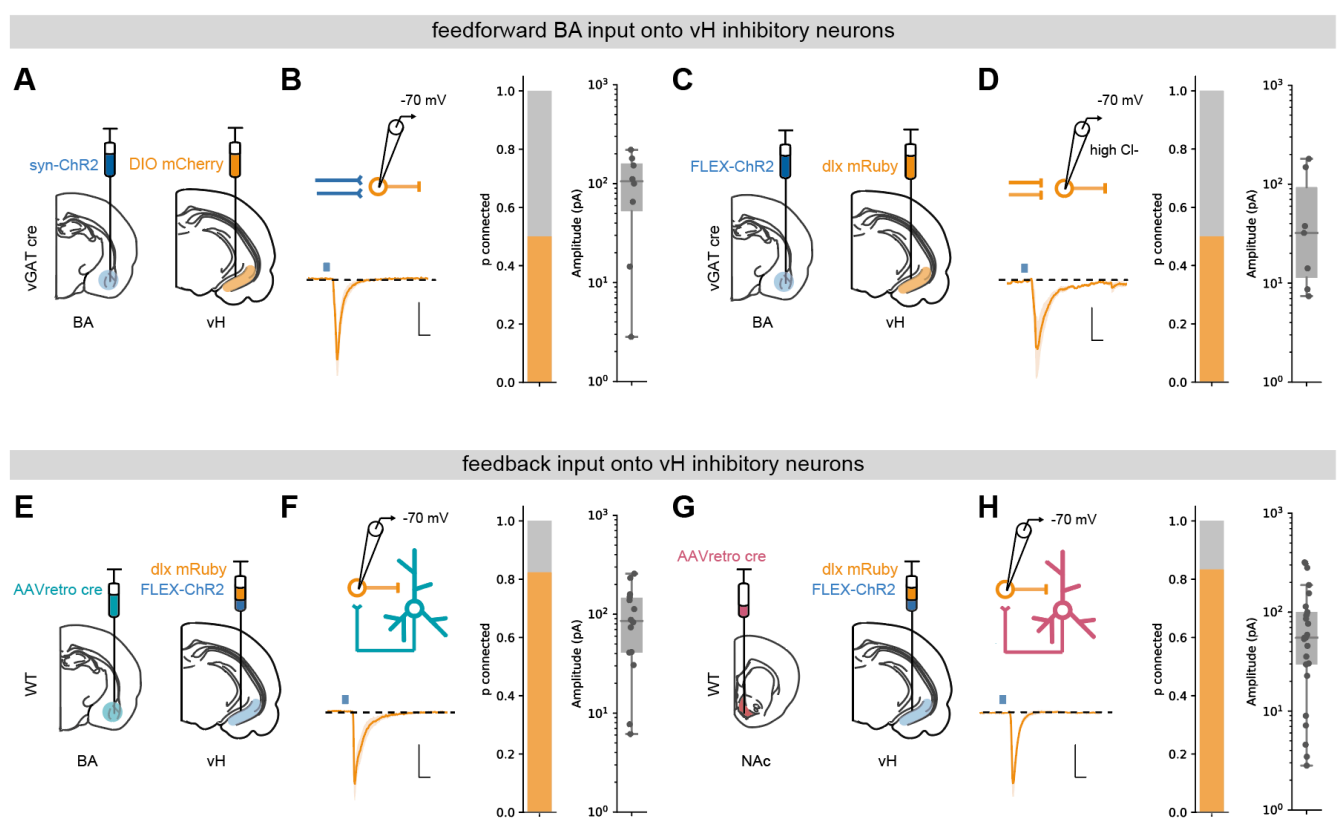

local inhibitory input onto $\mathrm{vH}$ output neurons
I

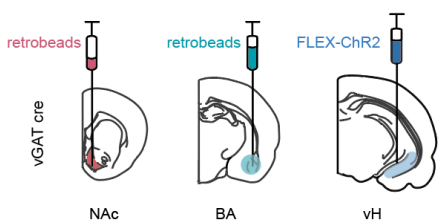

J

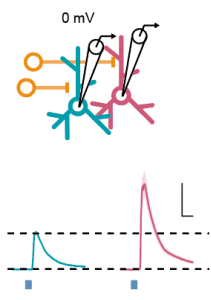

K

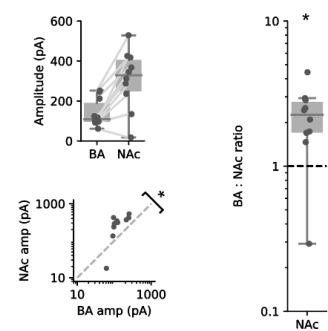

feedforward inhibitory input onto $\mathrm{vH}$ output neurons

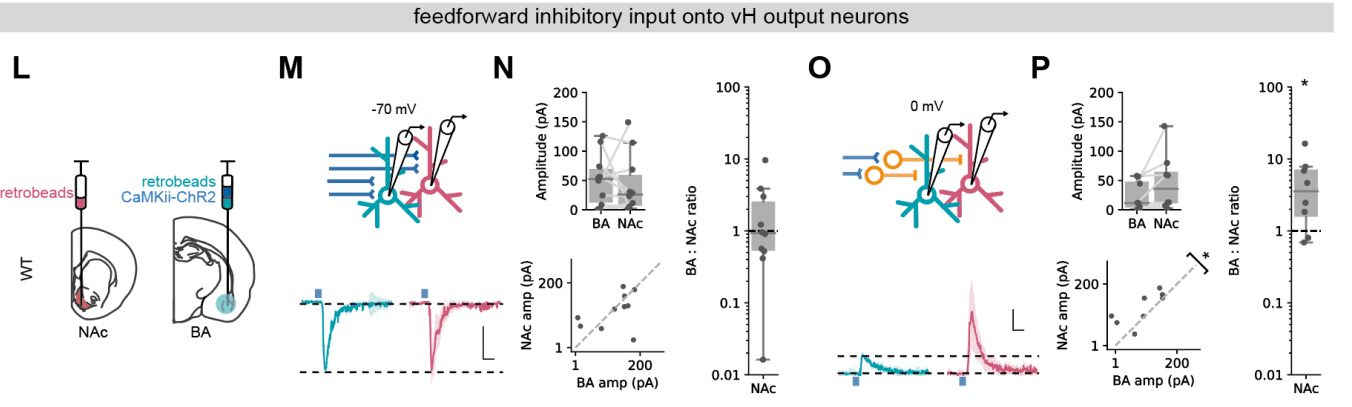

Figure 4 | BA input interacts with local inhibitory circuitry that is biased towards $\mathrm{vH}^{\mathrm{NAC}}$ neurons.

A. schematic of experiment. ChR2 was expressed in BA, and DIO mCherry was expressed in vH in vGAT:cre mice to label local interneurons.

\section{B. Left, Recording} configuration to record excitatory connectivity at -70 $\mathrm{mV}$ (top). Average light evoked current in interneurons in $\mathrm{vH}$. Scale bar $=50 \mathrm{pA}, 10 \mathrm{~ms}$. Right, Summary of probability of connection (left) and amplitude of connected currents (right).

C,D. As A, B but for inhibitory input isolated using FLEX ChR2 expression in vGAT:cre mice as before. Note recordings were performed in high $\mathrm{Cl}-$, so inward currents were measured at $-70 \mathrm{mV}$.

E. Experimental setup for investigating feedback connectivity from $\mathrm{vH}^{\mathrm{BA}}$ neurons. AAVretro was injected into BA, and FLEX $\mathrm{ChR} 2$ and dlx-mRuby into $\mathrm{vH}$ to allow recordings from $\mathrm{dl} x+$ interneurons, and measurement of light evoked currents from $\mathrm{vH}^{\mathrm{BA}}$ activation.

F. Left, Recording configuration to record excitatory connectivity at $-70 \mathrm{mV}$ (top). Average light evoked current in $\mathrm{dlx}+$ interneurons in $\mathrm{vH}$. Right, Summary of probability of connection (left) and amplitude of connected currents (right).

G,H. As E,F but for feedback input from $\mathrm{vH}^{\mathrm{NAC}}$ neurons.

I. Schematic of experiment, $\mathrm{vH}^{\mathrm{NAc}}$ and $\mathrm{vH}^{\mathrm{BA}}$ cells were labelled with injections of retrobeads, while $\mathrm{ChR} 2$ was expressed in $\mathrm{vH}$ interneurons using FLEX ChR2 in a vGAT::cre mouse.

J. Paired, fluorescently targeted recordings from neurons in each pathway at $0 \mathrm{mV}$ and recording of light evoked currents. Top, recording setup. Bottom, average light evoked currents in $\mathrm{vH}^{\mathrm{BA}}$ (green) and $\mathrm{vH}^{\mathrm{NAc}}($ red $)$ neurons. Scale bar $=1 \mathrm{vH}-\mathrm{BA}$ response, $10 \mathrm{~ms}$.

K. Summary of amplitude of light evoked BA input in pairs of $\mathrm{vH}^{\mathrm{NAc}}$ and $\mathrm{vH}^{\mathrm{BA}}$ neurons (top). When displayed as a scatter plot (bottom), or as the ratio of $\mathrm{vH}^{\mathrm{NAc}}$ : $\mathrm{vH}^{\mathrm{BA}}$ (right), the amplitudes cluster above the line of unity, indicating that local inhibition preferentially innervates $\mathrm{vH}^{\mathrm{NAc}}$ neurons. Note log axis.

L-N. as I, $\mathbf{J}$ but for CaMKii input recorded at $-70 \mathrm{mV}$. Note as in Figure 3 there is equal input onto both populations. Scale bar $=0.5 \mathrm{vH}^{\mathrm{BA}}$ response, $10 \mathrm{~ms}$.

$\mathbf{O}, \mathbf{P}$. as in $\mathbf{M}, \mathbf{N}$ but recording at $0 \mathrm{mV}$ to isolate feedforward inhibition. Note that the amplitudes cluster above the line of unity, indicating that feedforward inhibition preferentially innervates $\mathrm{vH}^{\mathrm{NAC}}$ neurons. Scale bar $=1 \mathrm{vH}-\mathrm{BA}$ response, $10 \mathrm{~ms}$.

1 We first asked whether BA excitatory and inhibitory input targeted interneurons in vH. To do this we combined 
bioRxiv preprint doi: https://doi.org/10.1101/2021.03 08.434367; this version posted March 8, 2021. The copyright holder for this preprint (which was not certified by peer review) is the author/funder, who has granted bioRxiv a license to display the preprint in perpetuity. It is made available under aCC-BY-NC-ND 4.0 International license.

2015; Dimidschstein et al., 2016). This allowed us to record from fluorescently identified interneurons in vH, and record light-evoked excitatory or inhibitory input from BA (Figure 4A-D). We found similar levels of both excitatory and inhibitory connectivity to input from BA onto local interneurons as we found with pyramidal neurons (in both cases $\sim 50 \%$ of recorded neurons were connected). Thus, both inhibitory and excitatory input from BA connect with local interneurons as well as pyramidal projection neurons in $\mathrm{vH}$.

We next wanted to investigate if $\mathrm{vH}^{\mathrm{BA}}$ and $\mathrm{vH}^{\mathrm{NAc}}$ neurons connected to local interneurons to form the basis of a feedback inhibitory circuit (S.-H. Lee et al., 2014). To do this we injected a retrogradely transported AAV (AAVretro) in either NAc and BA to express cre recombinase in NAc or BA projecting $\mathrm{vH}$ neurons respectively. In the same surgery we injected a combination of cre-dependent ChR2 and the fluorescent reporter dlx-mRuby into $\mathrm{vH}$. This allowed us to obtain whole cell recordings from fluorescently identified $\mathrm{vH}$ interneurons, while activating neighbouring projection neurons. Voltage clamp recordings at $-70 \mathrm{mV}$ showed robust responses from both $\mathrm{vH}^{\mathrm{NAc}}$ and $\mathrm{vH}^{\mathrm{BA}}$ neurons onto local interneurons ( $80 \%$ of recorded neurons were connected in each condition, Figure $4 \mathrm{E}-\mathrm{H})$, confirming previous studies suggesting strong feedback inhibition in $\mathrm{vH}(\mathrm{S} . \mathrm{H}$. Lee et al., 2014).

Finally, we asked if local interneurons differentially innervate $\mathrm{vH}^{\mathrm{BA}}$ and $\mathrm{vH}^{\mathrm{NAc}}$ neurons. We expressed ChR2 in vGAT+ interneurons in vH using a vGAT::cre mouse line, and injected different coloured retrobeads into NAc and $\mathrm{BA}$. Two weeks later we then obtained paired, whole cell recordings from $\mathrm{vH}^{\mathrm{BA}}$ and $\mathrm{vH}^{\mathrm{NAc}}$ neurons, and investigated light-evoked inhibitory synaptic input at $0 \mathrm{mV}$. We found that local inhibitory connectivity was markedly biased towards $\mathrm{vH}^{\mathrm{NAc}}$ neurons (Figure $4 \mathrm{I}-\mathrm{K}$ ), where inhibitory connections onto $\mathrm{vH}^{\mathrm{NAc}}$ neurons were on average twice the strength of those onto neighbouring $\mathrm{vH}^{\mathrm{BA}}$ neurons. Thus, activation of local interneurons in $\mathrm{vH}$, either via direct input from BA or via feedback from local pyramidal neurons, results in biased inhibition of $\mathrm{vH}^{\mathrm{NAC}}$ neurons, and has a much smaller effect of neighbouring $\mathrm{vH}^{\mathrm{BA}}$ neurons.

This marked asymmetry of local inhibitory connectivity led us to predict that feedforward inhibition activated by excitatory BA input may also differentially impact the two output populations. We tested this using ChR2 expressed in BA under the control of the CaMKii promoter to limit expression to excitatory projections. As before, excitatory input in this experiment was equivalent in both $\mathrm{vH}^{\mathrm{BA}}$ and $\mathrm{vH}^{\mathrm{NAc}}$ neurons (Figure $4 \mathrm{~L}-\mathrm{N}$ ). In contrast, and as predicted, feedforward inhibition recorded at $0 \mathrm{mV}$ was markedly biased towards $\mathrm{vH}^{\mathrm{NAc}}$ neurons (Figure $40, P)$.

Together these experiments show that local interneurons in $\mathrm{vH}$ make biased connections onto $\mathrm{vH}^{\mathrm{NAc}}$ neurons. This biased innervation of interneurons towards $\mathrm{vH}^{\mathrm{NAc}}$ neurons suggests greater influence of both feedforward inhibition from BA, but also feedback inhibition resulting from activation of local pyramidal neurons.

\section{A circuit model predicts a role for long range inhibition in promotion of $\mathrm{vH}^{\mathrm{NAc}}$ activity}

Our results so far suggest that the connectivity of both excitatory and inhibitory BA input into vH is very specific, and interacts with a number of interconnected elements in the local $\mathrm{vH}$ circuit. In order to investigate the overall 
A

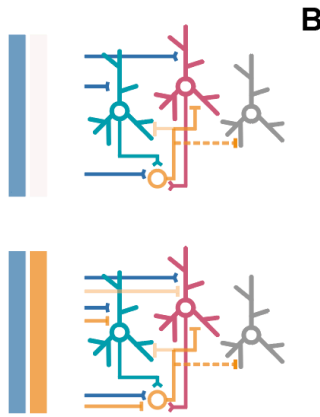

B
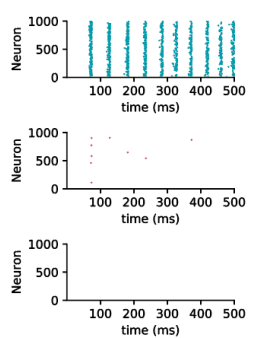
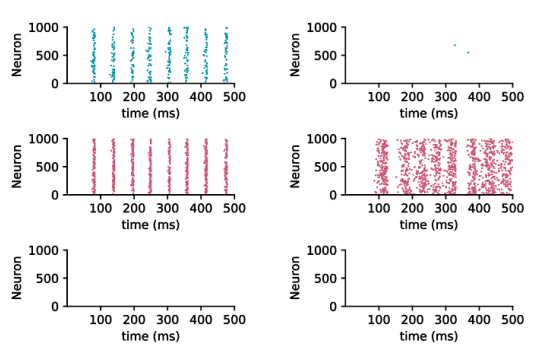

C

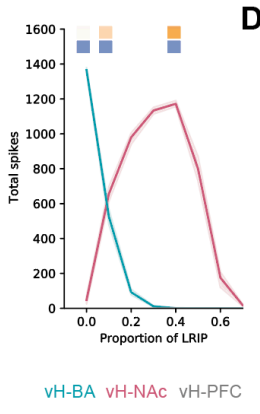

D

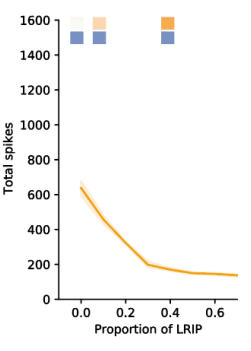

Figure 5 | Co-activation of inhibitory and excitatory input switches $\mathrm{vH}$ activity from $\mathrm{vH}^{\mathrm{BA}}$ to $\mathrm{vH}^{\mathrm{NAc}}$

A. Schematic of integrate and fire model. Three populations of projection neurons $\left(\mathrm{vH}^{\mathrm{NAc}}, r e d ; \mathrm{vH}^{\mathrm{BA}}\right.$, green; $\mathrm{vH}^{\mathrm{PFC}}$, grey) and local interneurons (orange) are innervated by excitatory (blue, top) as well as inhibitory (orange, bottom) BA input. Connectivity is defined from results in previous figures.

B. Increasing the proportion of inhibitory relative to excitatory $\mathrm{BA}$ input has opposite effects on $\mathrm{vH}^{\mathrm{BA}}$ and $\mathrm{vH}^{\mathrm{NAc}}$ spiking. Each graph shows a raster of spiking for each neuron across a $500 \mathrm{~ms}$ period. Note high $\mathrm{vH}^{\mathrm{BA}}$ spiking with no inhibitory input, and high $\mathrm{vH}^{\mathrm{NAc}}$ spiking with high inhibitory input. $\mathrm{vH}^{\mathrm{PFC}}$ neurons never fire as they are not innervated by $\mathrm{BA}$, and only receive background input.

C. Summary of pyramidal neuron activity. With increasing inhibitory input, activity shifted from $\mathrm{vH}^{\mathrm{BA}}$ to $\mathrm{vH}^{\mathrm{NAc}}$ neurons. Markers indicate proportions plotted in $\mathbf{B}$.

D. Long range inhibition reduces local interneuron firing, removing preferential feedback inhibition onto $\mathrm{vH}^{\mathrm{NAC}}$ neurons, allowing them to fire.

influence of BA input in a more holistic way, we built a simple integrate-and-fire network (Stimberg et al., 2019), containing three separate projection populations in $\mathrm{vH}$ (to BA, NAc and PFC), local interneurons, excitatory and inhibitory input from $B A$, and background synaptic input from other structures. We then constrained the connectivity between these groups of neurons using the results of our circuit analysis (Figure 5A).

We first looked at excitatory $\mathrm{BA}$ input alone, and found that this robustly activated $\mathrm{vH}^{\mathrm{BA}}$ neurons in our model and had no effect on $\mathrm{vH}^{\mathrm{PFC}}$ activity - consistent with the lack of connectivity to this population (see Figure 3). However, there was also a marked lack of $\mathrm{vH}^{\mathrm{NAc}}$ activity, despite these neurons receiving equivalent excitatory synaptic input from BA. This was due to asymmetrical targeting by local inhibition (see Figure 4), and thus a combination of feedback and feedforward inhibition effectively silencing $\mathrm{vH}^{\mathrm{NAc}}$ neurons, despite them receiving excitatory drive.

We next incrementally added increasing proportions of long-range inhibitory input from BA to the model, such that there was co-activation of both long-range inhibitory AND excitatory input. We found that increasing inhibitory input resulted in a switch in the activity of the different populations (Figure $5 \mathrm{~B}, \mathrm{C}$ ). While $\mathrm{vH}^{\mathrm{PFC}}$ neurons remained silent, $\mathrm{vH}^{\mathrm{NAc}}$ neuron activity increased as direct inhibition increased, and $\mathrm{vH}^{\mathrm{BA}}$ neuron activity decreased. This difference peaked around $40 \%$ long range inhibition, where $\mathrm{vH}^{\mathrm{BA}}$ neurons were effectively silent, and $\mathrm{vH}^{\mathrm{NAC}}$ neurons were firing robustly. This was due to long range inhibition efficiently removing feedforward and feedback inhibition onto $\mathrm{vH}^{\mathrm{NAC}}$ neurons (Figure 5D) - both by direct inhibition of local interneuron activity, but also by inhibiting $\mathrm{vH}^{\mathrm{BA}}$ neurons that provide the bulk of feedback inhibitory drive. This effect was robust across a wide range of feedforward and feedback connectivity (Figure S3).

This circuit analysis suggests that specific connectivity of excitatory $\mathrm{BA}$ input into $\mathrm{vH}$ may not be the major determinant of $\mathrm{vH}^{\mathrm{BA}}$ and $\mathrm{vH}^{\mathrm{NAc}}$ neuron activity. In fact, it is the presence of direct inhibitory input from $\mathrm{BA}$ that 
bioRxiv preprint doi: https://doi.org/10.1101/2021.03.08.434367; this version posted March 8, 2021. The copyright holder for this preprint (which was not certified by peer review) is the author/funder, who has granted bioRxiv a license to display the preprint in perpetuity. It is made available under aCC-BY-NC-ND 4.0 International license.

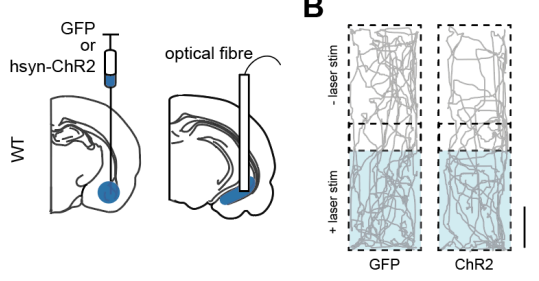

D

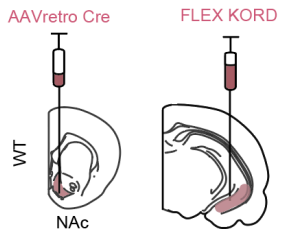

$\mathbf{E}$
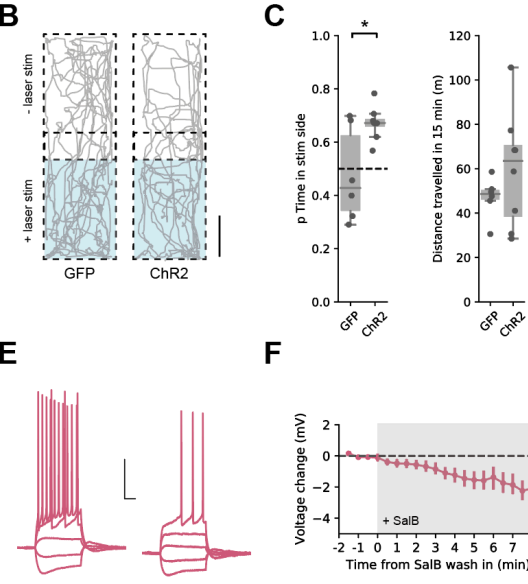

$\mathbf{F}$

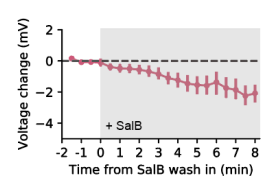

G

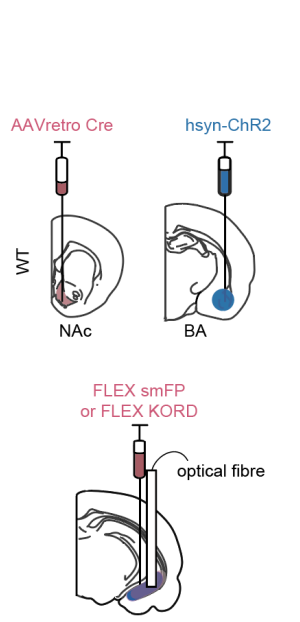

H

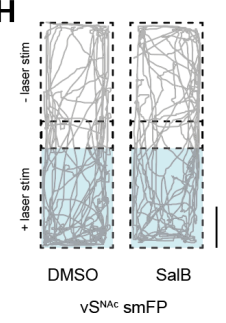

J

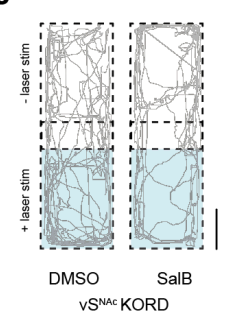

I

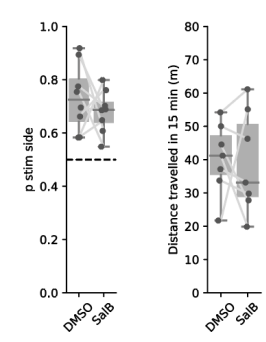

K

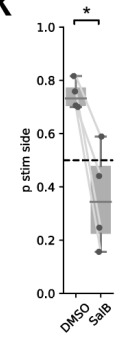

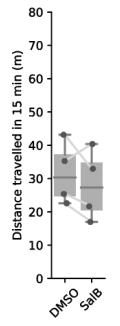

Figure 6 | BA input supports real time place preference dependent on $\mathrm{vH}^{\mathrm{NAC}}$ neurons.

A. Schematic of experiment. GFP or pan-neuronal ChR2 were expressed in $\mathrm{BA}$, and an optic fibre implanted in $\mathrm{vH}$.

B. Real time place preference (RTPP) assay. One side of a chamber was paired with $20 \mathrm{~Hz}$ blue light stimulation. Example trajectories of GFP (left) and ChR2 (right) expressing animals over the 15 min RTPP session. Note increased occupancy of light-paired (stim) side in ChR2 animals. Scale bar $=15 \mathrm{~cm}$.

C. Summary of RTPP. Left, Proportion of time spent on stim side (left) and total distance travelled (right) in GFP and ChR2 animals. Note consistent preference for stim side in ChR2 animals.

D. Strategy to express KORD in $\mathrm{vH}^{\mathrm{NAc}}$ neurons.

E,F. Bath application of SalB $(100 \mathrm{~nm})$ hyperpolarises $\mathrm{KORD}$ expressing $\mathrm{vH}^{\mathrm{NAc}}$ neurons, and reduces $\mathrm{AP}$ firing. See Figure S4 for full quantification. Scale bar $=30 \mathrm{mV}$, $100 \mathrm{~ms}$.

G. Schematic of strategy to inhibit $\mathrm{vH}^{\mathrm{NAc}}$ neurons during $\mathrm{BA}$ input driven RTPP.

H,I. As B,C but comparing the effect of either DMSO (vehicle) or SalB (KORD agonist) injections 15 mins before testing in control mice. Note consistent RTPP in both conditions indicating no effect of SalB in control mice.

$\mathbf{J}, \mathbf{K}$. As $\mathbf{H}, \mathbf{I}$, but in mice expressing $\mathrm{KORD}$ in $\mathrm{vH}^{\mathrm{NAc}}$ neurons. Note loss of RTPP in SalB injected mice compared to controls.

defines which projection population is active. With

no inhibition present, activity is confined to a reciprocal projection back to BA, however, when inhibition is present there is a switch to increased activity to NAc.

\section{$B A$ input to $\mathrm{vH}$ can support $\mathrm{RTPP}$ via activation of $\mathrm{vH}^{\mathrm{NAc}}$ neurons}

A hallmark of activation of $\mathrm{vH}^{\mathrm{NAc}}$ activation is the ability to promote real-time place preference (RTPP, Britt et al., 2012; LeGates et al., 2018). The results of our circuit modelling suggested that co-activation of BA inhibitory and excitatory input to $\mathrm{vH}$ results in $\mathrm{vH}^{\mathrm{NAc}}$ activation. We reasoned that $\mathrm{BA}$ input to $\mathrm{vH}$ may also support RTPP via activation of $\mathrm{vH}^{\mathrm{NAc}}$ neurons in vivo, and that this would depend on the coactivation of inhibitory as well as excitatory BA projections.

We tested if activation of both excitatory and inhibitory BA input supported RTPP by unilaterally injecting either GFP, or ChR2 under the pan-neuronal synapsin promoter into BA, and implanting optical fibres in vH (Figure 6A). We then carried out a RTPP test where one side of a rectangular arena was paired with $20 \mathrm{~Hz}$ blue light stimulation of $\mathrm{BA}$ terminals in $\mathrm{vH}$. Consistent with our circuit analysis showing $\mathrm{BA}$ input activating $\mathrm{vH}^{\mathrm{NAc}}$ neurons, 
this stimulus supported RTPP in ChR2 expressing animals compared to GFP controls, with no change in the total distance moved during the session (Figure 6B,C).

From our circuit model, we predicted that this RTPP should be abolished by a reduction in the activity of $\mathrm{vH}^{\mathrm{NAc}}$ neurons. We next directly tested this using a combination of optogenetic RTPP to activate BA input, and the Kappa Opioid Receptor Designer receptor exclusively activated by designer drugs (KORD) to reversibly inhibit $\mathrm{vH}^{\mathrm{NAc}}$ neurons (Vardy et al., 2015). We first tested the efficacy of KORDs expressed in $\mathrm{vH}^{\mathrm{NAc}}$ neurons, and confirmed that the KORD agonist salvinorin $\mathrm{B}(\mathrm{SalB})$ hyperpolarised $\mathrm{vH}^{\mathrm{NAc}}$ neurons, and resulted in a decrease in current-induced action potential firing (Figure 6D-F, Figure S4). We next combined this KORD mediated inhibition with the optogenetic RTPP assay. We expressed pan-neuronal ChR2 in BA, KORDs in vH ${ }^{\mathrm{NAc}}$ neurons, and implanted an optical fibre unilaterally in vH (Figure 6G). We then carried out the RTPP assay 15 mins after a subcutaneous injection of either SalB, or vehicle control (DMSO, Figure $6 \mathrm{H}-\mathrm{K}$ ). We found that after DMSO injection, there was still robust RTPP in both control and KORD expressing mice. After SalB, control animals again still had robust RTPP. However, after injection of SalB in KORD expressing animals, RTPP was abolished. Together these experiments support our circuit model, where coactivation of both excitatory and inhibitory BA input to $\mathrm{vH}$ supports real time place preference through the activation of $\mathrm{vH}^{\mathrm{NAc}}$ neurons.

\section{Excitatory BA input to $\mathrm{vH}$ supports RTPP only when $\mathrm{vH}^{\mathrm{BA}}$ activity is inhibited.}

In contrast to activation of both excitatory and inhibitory $\mathrm{BA}$ input into $\mathrm{vH}$, another prediction from our circuit modelling is that excitatory $\mathrm{BA}$ input alone would not activate $\mathrm{vH}^{\mathrm{NAc}}$ neurons, and thus would not support RTPP. We tested this prediction using ChR2 expressed under the CaMKii promoter to target only excitatory BA input to $\mathrm{vH}$ (see Figure 2). We injected either GFP or ChR2 under the CaMKii promoter in BA and implanted an optical fibre in $\mathrm{vH}$, before carrying out an RTPP assay as before (Figure 7A). Consistent with the predictions from our circuit analysis, this assay showed that the light stimulus was unable to support RTPP in either GFP or ChR2 expressing animals (Figure 7B,C).

Our reasoning for this lack of RTPP was that excitatory $\mathrm{BA}$ input results in $\mathrm{vH}^{\mathrm{BA}}$ neuron activity, and this recruits strong local feedback inhibition that preferentially reduces the activity of $\mathrm{vH}^{\mathrm{NAc}}$ neurons (Figure 5 ) that are required to support RTPP (Figure 6). We therefore hypothesised that reducing $\mathrm{vH}^{\mathrm{BA}}$ neuron activity (in effect mimicking the effect of the direct $\mathrm{BA}$ inhibitory projection) may increase $\mathrm{vH}^{\mathrm{NAc}}$ activity and support RTPP from only excitatory $\mathrm{BA}$ input. This reasoning was supported our circuit model, where removing $\mathrm{vH}^{\mathrm{BA}}$ activity increased the activity of $\mathrm{vH}^{\mathrm{NAc}}$ neurons when no BA inhibitory input was present (Figure S5).

To test this hypothesis, we first ensured $\mathrm{KORD}$-expressing $\mathrm{vH}^{\mathrm{BA}}$ neuron excitability was inhibited by bath application of SalB (Figure 7D-F, Figure S4). Next, we injected ChR2 under the CaMKii promoter in BA to target only excitatory input into $\mathrm{vH}$. In the same surgery we combined this with an injection of AAVretro cre in BA and cre-dependent $\mathrm{KORD}$ in $\mathrm{vH}$ to target $\mathrm{vH}^{\mathrm{BA}}$ neurons, and implanted an optical fibre unilaterally in $\mathrm{vH}$ (Figure $7 \mathrm{~J}$ ). After allowing for expression, we then performed the RTPP assay 15 mins after injection of either SalB, or vehicle 
bioRxiv preprint doi: https://doi.org/10.1101/2021.03.08.434367; this version posted March 8, 2021. The copyright holder for this preprint (which was not certified by peer review) is the author/funder, who has granted bioRxiv a license to display the preprint in perpetuity. It is made available under aCC-BY-NC-ND 4.0 International license.

A

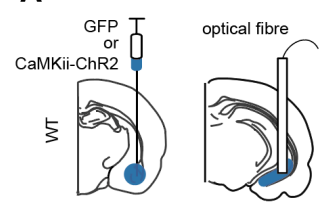

D

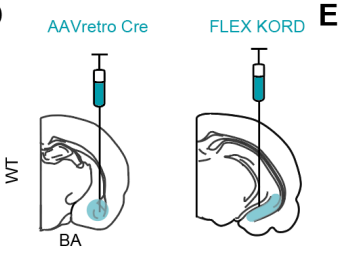

G

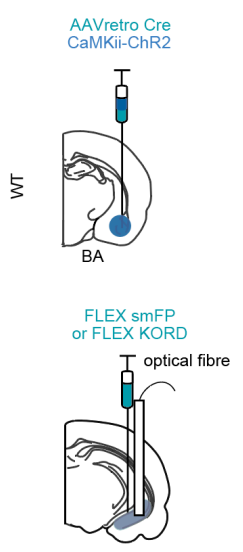

B

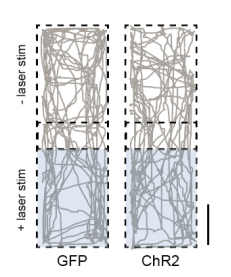

E

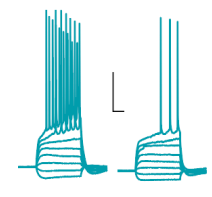

H

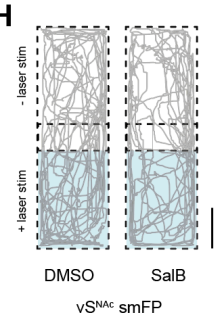

$\mathbf{J}$

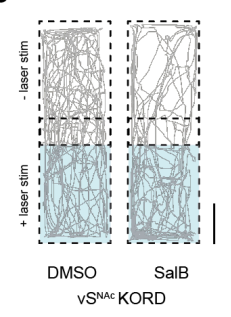

C
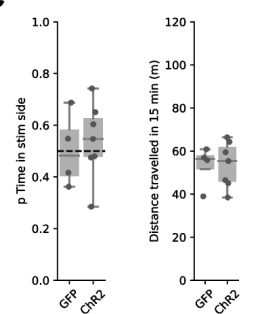

$\mathbf{F}$

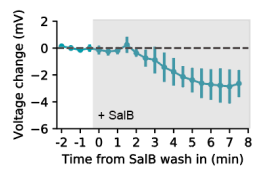

Figure 7 | Excitatory BA input supports real time place preference only after inhibition of $\mathrm{vH}^{\mathrm{BA}}$ neurons.

A. Schematic of experiment. GFP or excitation-specific CaMKii ChR2 were expressed in BA, and an optic fibre implanted in $\mathrm{vH}$.

B. Real time place preference (RTPP) assay. One side of a chamber was paired with $20 \mathrm{~Hz}$ blue light stimulation. Example trajectories of GFP (left) and ChR2 (right) expressing animals over the 15 min RTPP session. Note lack of preference for light-paired (stim) side in either group. Scale bar $=15 \mathrm{~cm}$

C. Summary of RTPP. Left, Proportion of time spent on stim side (left) and total distance travelled (right) in GFP and ChR2 animals. Note lack of preference for stim side in either condition.

D. Strategy to express $\mathrm{KORD}$ in $\mathrm{vH}^{\mathrm{BA}}$ neurons.

E,F. Bath application of SalB $(100 \mathrm{~nm})$ hyperpolarises KORD expressing $\mathrm{vH}^{\mathrm{BA}}$ neurons, and reduces AP firing. See Figure S4 for full quantification. Scale bar $=30 \mathrm{mV}$, $100 \mathrm{~ms}$.

G. Schematic of strategy to inhibit $\mathrm{vH}^{\mathrm{BA}}$ neurons during $\mathrm{BA}$ input driven RTPP.

$\mathbf{H}, \mathbf{I}$. As B,C but comparing the effect of either DMSO (vehicle) or SalB (KORD agonist) injections 15 mins before testing in control mice. Note lack of RTPP in both conditions indicating no effect of SalB in control mice.

K

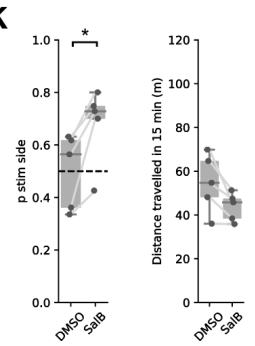

$\mathbf{J , K}$. As $\mathbf{H}, \mathbf{l}$, but in mice expressing $\mathrm{KORD}$ in $\mathrm{vH}^{\mathrm{BA}}$ neurons. Note induction of RTPP in SalB injected mice compared to controls.

control as before (Figure $7 \mathrm{H}-\mathrm{K}$ ). Consistent with _ our previous results, there was no RTPP in either

group after DMSO injections, or in control animals after SalB injection. However, after SalB injections in KORD expressing animals, light stimulation now supported RTPP.

This experiment supports our hypothesis that $\mathrm{vH}^{\mathrm{NAc}}$ activity and hence RTPP is crucially dependent on the activity of both excitatory and inhibitory input from BA. Excitatory BA input to $\mathrm{VH}$ can only support RTPP if accompanied by inhibition of BA-projecting $\mathrm{vH}$ neurons, in effect mimicking the effect of BA inhibitory input on the circuit. Our model predicts that this reduction in $\mathrm{vH}^{\mathrm{BA}}$ activity removes local feedback inhibition (Figure S5), and allows excitatory $\mathrm{BA}$ input to drive $\mathrm{vH}^{\mathrm{NAc}}$ activity, which can support place preference. 
bioRxiv preprint doi: https://doi.org/10.1101/2021.03.08.434367; this version posted March 8, 2021. The copyright holder for this preprint (which was not certified by peer review) is the author/funder, who has granted bioRxiv a license to display the preprint in perpetuity. It is made available under aCC-BY-NC-ND 4.0 International license.

\section{DISCUSSION}

In this study, we have defined a novel long-range inhibitory projection from BA to ventral hippocampus. We show that this novel projection exists in concert with a parallel excitatory projection, and that the presence of its inhibitory influence can dramatically shift $\mathrm{vH}$ output in response to $\mathrm{BA}$ activity. While excitation alone preferentially drives a reciprocal projection back to BA, coactivation of both excitatory and inhibitory input preferentially drives a separate projection to NAc, that can support place-value associations.

We found that in addition to classically described excitatory input from $\mathrm{BA}$ to $\mathrm{vH}$, there was also direct inhibitory projection (Figures 1,2). Excitatory input from BA to $\mathrm{vH}$ has been widely studied, and is distributed across a large range of subnuclei, ranging from the MEA to the BLA, and well as cortical amygdala (McDonald and Mott, 2016). Each of the distinct nuclei of the amygdala are thought to control various aspects of cue-dependent learning and carry out unique roles during behaviour. Increasingly, function has been assigned to BA based on anatomical location. For example, anterior basolateral, basomedial and central amygdala have unique contributions to fear learning and extinction (Adhikari et al., 2015; Ciocchi et al., 2010; Kim et al., 2016; LeDoux, 2000), while more posterior and medial regions of BA are increasingly associated with reward-learning, value calculations and prosocial behaviours (Chen et al., 2019; Kim et al., 2016; Lutas et al., 2019; Malvaez et al., 2019; Pi et al., 2020; Shemesh et al., 2016). However, the role within each of these nuclei is also diverse - with interspersed neurons involved in encoding behaviour across a wide range of different situations (Beyeler et al., 2016; Felix-Ortiz et al., 2013; Felix-Ortiz and Tye, 2014; Gründemann et al., 2019; Kim et al., 2016; Namburi et al., 2015). We found that the BA inhibitory projection arose from GABAergic neurons interspersed between excitatory projection neurons throughout the entire extent of the BA (Figure S2). Thus, in addition to systematically investigating the synaptic targeting and behavioural contribution of the input from different nuclei separately, it will be important to assess the differential contribution of excitatory and inhibitory drive, most likely through the use of intersectional genetic and anatomical approaches (Fenno et al., 2014; Kim et al., 2016).

Our results suggest that inhibitory input from BA to vH may be important for motivated behaviour, in particular we show that coactivation of both excitatory and inhibitory projections from BA, and not excitation alone, is essential for promoting place-value associations (Figure 6,7). Long range inhibitory projections from classical excitatory projection areas have been increasingly identified as having a key role in shaping circuit output and for defining motivated behaviour. For example, functional inhibitory projections from PFC to NAc (A. T. Lee et al., 2014), and BA to PFC (Seo et al., 2016) have both been shown to modulate value-based and reward behaviour, including the support of real time place preference and aversion. The hippocampus also receives long range inhibitory input from numerous regions including entorhinal cortex (Basu et al., 2016; Melzer et al., 2012), septum (Schlesiger et al., 2021) and PFC (Malik et al., 2021). While these studies focussed on dorsal hippocampal circuitry and a role for these projections in memory and navigation, due to the known dichotomy between dorsal and ventral hippocampal function (Fanselow and Dong, 2010; Strange et al., 2014), it would be interesting to investigate the presence and function of such long range inhibitory projections into $\mathrm{vH}$. In particular whether a role in motivated behaviour and place preference was specific to BA input, or due to the dorso-ventral location of this input in hippocampus. Interestingly, long range inhibition from entorhinal cortex, septum and PFC 
bioRxiv preprint doi: https://doi.org/10.1101/2021.03.08.434367; this version posted March 8, 2021. The copyright holder for this preprint (which was not certified by peer review) is the author/funder, who has granted bioRxiv a license to display the preprint in perpetuity. It is made available under aCC-BY-NC-ND 4.0 International license.

all preferentially target interneurons and avoid pyramidal neurons (Basu et al., 2016; Malik et al., 2021; Melzer et al., 2012; Schlesiger et al., 2021). In contrast our data shows that BA long range inhibition connects with both interneurons and pyramidal neurons (Figure 3), similar to that seen in long range inhibitory projections from BA to PFC (Seo et al., 2016). This suggests that there may at least in part be interesting input specific connectivity across the different long range inhibitory inputs into hippocampus.

We investigated the synaptic and circuit basis by which BA input could promote such motivated behaviour. The ventral hippocampus is increasingly viewed as being composed as a series of parallel output streams, where pyramidal neurons in the CA1 / subiculum border are composed of multiple populations each projecting to a distinct downstream region including the NAc, the PFC and the BA. Each projection population in vH underlies a unique role during behaviour. In particular, $\mathrm{vH}^{\mathrm{NAc}}$ neurons have been shown to be key for motivated behaviour, and the association of reward with a particular place or time (Britt et al., 2012; Ciocchi et al., 2015; LeGates et al., 2018; Okuyama et al., 2016; Trouche et al., 2019). We found that both excitatory and inhibitory input from BA made specific connections onto each of these projection populations (Figure 3, 4, 5), such that the balance of excitation and inhibition from $\mathrm{BA}$ into $\mathrm{vH}$ is well placed to determine their relative activity. Excitatory input alone preferentially activated $\mathrm{vH}^{\mathrm{BA}}$ neurons, while excitatory and inhibitory input together preferentially activated $\mathrm{vH}^{\mathrm{NAc}}$ neurons (Figure 5). Thus, BA input is well placed to define the activity of specific vH output pathways in response to a particular environment, state or task. More specifically, the level of inhibitory input form BA can control real time place preference by defining the activity of $\mathrm{vH}^{\mathrm{NAc}}$ neurons (Figure 6,7).

In addition to the role of $\mathrm{BA}$ and $\mathrm{vH}$ in value based and motivated behaviour, multiple studies have examined the role of excitatory BLA input into vH in the generation of anxiety-like behaviour (Felix-Ortiz et al., 2013; Pi et al., 2020). The $\mathrm{vH}$ has a key role in the generation of appropriate behaviour in anxiogenic environments (Gray and McNaughton, 2003; Kjelstrup et al., 2002; McHugh et al., 2004). This is thought to be achieved both by resolving approach avoidance conflict during decision making via $\mathrm{vH}^{\mathrm{PFC}}$ projection neurons (Padilla-Coreano et al., 2016; Sanchez-Bellot and MacAskill, 2020), but recently also via generation of a specific anxiogenic state defined via projections to the lateral hypothalamus (LH, Jimenez et al., 2018). Neither excitatory or inhibitory BA input connect with $\mathrm{vH}^{\mathrm{PFC}}$ neurons (Figure 3), suggesting innervation from other local or long-range afferent regions may be key for this behavioural role (Sanchez-Bellot and MacAskill, 2020). However, BA input does innervate $\mathrm{vH}^{\mathrm{LH}}$ neurons (Gergues et al., 2020; Wee and MacAskill, 2020), and thus it is interesting to note the possibility that the anxiogenic influence of excitatory, anterior BLA input (Felix-Ortiz et al., 2013; Pi et al., 2020) may be via this distinct circuit. $\mathrm{vH}^{\mathrm{LH}}$ neurons are present in more distal areas of ventral subiculum, with only a minority present in the CA1/proximal subiculum border region considered in this study (Wee and MacAskill, 2020). However, how BA input interacts with distal subicular circuits that project to distinct downstream regions including hypothalamus and retrosplenial cortex (Cembrowski et al., 2018; Kim and Spruston, 2012); and how inhibitory and excitatory input interact with this circuit is an interesting future direction.

Finally, our study focussed on the postsynaptic influence of BA inhibitory projections, and the molecular identity of these projection neurons remains unknown. Anatomical studies have suggested that BA inhibitory projections are preferentially observed in somatostatin (SOM)- and neuropeptide $\mathrm{Y}$ (NPY)-expressing neurons (McDonald et al., 2012; McDonald and Zaric, 2015), and almost completely absent in parvalbumin (PV)- and vasoactive 
bioRxiv preprint do: https://doi.org/10.1101/2021.03 08.434367: this version posted March 8,2021 . The copyright holder for this preprint (which was not certified by peer review) is the author/funder, who has granted bioRxiv a license to display the preprint in perpetuity. It is made available under aCC-BY-NC-ND 4.0 International license.

intestinal peptide (VIP)-expressing neurons. Thus, there is the potential for inhibitory input to be from both specific nuclei in BA (Figure 1, Figure S2), but also different genetically defined populations of inhibitory neurons, as is seen for excitatory amygdala projections (Kim et al., 2016). Similarly, in our study we did not differentiate $\mathrm{BA}$ input onto different types of inhibitory interneuron in $\mathrm{vH}$. There is enormous diversity of interneuron types throughout the hippocampus (Group et al., 2008), each of which involved in distinct parts of the circuit calculation - such as dendritic targeting SOM- and VIP-expressing neurons, perisomatic PV-expressing interneurons, and cholecystokinin- (CCK) expressing interneurons. Inhibitory input from entorhinal cortex preferentially innervates CCK interneurons (Basu et al., 2016), while input from PFC specifically innervates VIP interneurons (Malik et al., 2021). Thus, how BA input differentially innervates these populations is an important and interesting future question.

Overall we have defined a novel circuit that allows BA input to define the activity of parallel output pathways from $\mathrm{vH}$ to control motivated behaviour. The anatomical and functional specificity of this circuit provides an ideal substrate upon which to control reward and value-based learning and decision making, and helps to explain the multiple and varied roles attributed to this circuit. 


\section{METHODS}

\section{Animals}

6 - 10 week old (adult) male and female C57 / bl6J mice provided by Charles River were used except where noted. To target inhibitory neurons we used the SIc32a1(VGAT)-IRES-Cre (\#016962) knock-in line obtained from Jackson laboratories and bred in-house. Mice were housed in cages of 2 - 4 and kept in a humidity- and temperature-controlled environment under a $12 \mathrm{~h}$ light/dark cycle (lights on $7 \mathrm{am}$ to $7 \mathrm{pm}$ ) with ad-libitum access to food and water. All experiments were approved by the U.K. Home Office as defined by the Animals (Scientific Procedures) Act, and University College London ethical guidelines.

\section{Stereotaxic surgery}

\section{Retrograde tracers:}

Red and Green fluorescent retrobeads (Lumafluor, Inc.) for electrophysiological recordings.

Cholera toxin subunit B (CTX $\beta$ ) tagged with Alexa 555, 488 or 647 (Molecular Probes) for histology experiments.

\section{Viruses:}

AAV2/1-CaMKII-GFP

AAV2retro-CAG-Cre

AAV2/1-EF1a-FLEX-hChR2(H134R)-EYFP

AAV2/1-hSyn-hChR2(H134R)-EYFP

AAV2/1-CaMKII-hChR2(H134R)-EYFP

pAAV2/8-hSyn-dF-HA-KORD-IRES-mCitrine

AAV2/1.CAG.FLEX.Ruby2sm-Flag.WPRE

AAV2/9-mDlx-NLS-mRuby2

pAAV2/1-Ef1a-fDIO mCherry (a gift from Edward Boyden; Addgene \#64545)

(UNC vector core)

(a gift from Karl Deisseroth; Addgene \#20298-AAV1)

(a gift from Karl Deisseroth; Addgene \#26973-AAV1)

(a gift from Karl Deisseroth; Addgene \#26969-AAV1)

(a gift from Bryan Roth; Addgene \#6541-AAV8)

(a gift from Loren Looger; Addgene \#98928-AAV1)

(a gift from Viviana Gradinaru; Addgene \#99130-AAV1)

(a gift from Karl Deisseroth ; Addgene 114471-AAV1)

\section{Surgery:}

Stereotaxic injections were performed on 7 - 10 week old mice anaesthetized with isofluorane (4\% induction, 1 - $2 \%$ maintenance) and injections carried out as previously described (Sanchez-Bellot and MacAskill, 2020; Wee and MacAskill, 2020). Briefly, the skull was exposed with a single incision, and small holes drilled in the skull directly above the injection site. Injections are carried out using long-shaft borosilicate glass pipettes with a tip diameter of $\sim 10-50 \mu \mathrm{m}$. Pipettes were back-filled with mineral oil and front-filled with $\sim 0.8 \mu \mathrm{l}$ of the substance to be injected. A total volume of $250-300 \mathrm{nl}$ of each virus was injected at each location in $\sim 14$ or $28 \mathrm{nl}$ increments every $30 \mathrm{~s}$. If two or more substances were injected in the same region they were mixed prior to injection. The pipette was left in place for an additional $10-15 \mathrm{~min}$ to minimize diffusion and then slowly removed. If optic fibres were also implanted, these were inserted immediately after virus injection, secured with 
1 - 2 skull screws and cemented in place with C\&B superbond. Injection coordinates were as follows (mm relative to bregma):

infralimbic PFC:

nucleus accumbens:

basal amygdala:

ventral hippocampus:

$\begin{array}{lll}M L: \pm 0.4, & R C:+2.3, & \text { and DV: }-2.4 \\ M L: \pm 0.9, & R C:+1.1, & \text { and DV: }-4.6 \\ M L: \pm 3.4, & R C:-1.7, & \text { and DV: }-5.8 \\ M L: \pm 3.2, & R C:-3.7, & \text { and DV: }-4.7\end{array}$

After injection, the wound was sutured and sealed, and mice recovered for $\sim 30 \mathrm{~min}$ on a heat pad before they were returned to their home cage. Animals received carprofen in their drinking water $(0.05 \mathrm{mg} / \mathrm{ml})$ for $48 \mathrm{hrs}$ post-surgery as well as subcutaneously during surgery $(0.5 \mathrm{mg} / \mathrm{kg})$. Expression occurred in the injected brain region for $\sim 2$ weeks for WT animals and $\sim 4$ weeks for vGAT animals until behavioural testing, preparation of acute slices for physiology experiments, or fixation for histology. The locations of injection sites were verified for each experiment.

\section{Anatomy}

\section{Histology:}

Mice were perfused with 4\% PFA (wt / vol) in PBS, pH 7.4, and the brains dissected and postfixed overnight at $4^{\circ} \mathrm{C}$ as previously described (MacAskill et al., 2014; Sanchez-Bellot and MacAskill, 2020; Wee and MacAskill, 2020). $70 \mu \mathrm{m}$ thick slices were cut using a vibratome (Campden Instruments) in either the transverse, coronal or sagittal planes as described in the figure legends. Slices were mounted on Superfrost glass slides with ProLong Gold or ProLong Glass (for visualization of GFP) antifade mounting medium (Molecular Probes). NucBlue was included to label gross anatomy. Imaging was carried out with a Zeiss Axio Scan Z1, using standard filter sets for excitation/emission at $365-445 / 50 \mathrm{~nm}, 470 / 40-525 / 50 \mathrm{~nm}, 545 / 25-605 / 70 \mathrm{~nm}$ and 640/30$690 / 50 \mathrm{~nm}$. Raw images were analyzed with FIJI.

\section{Whole Brain Registration:}

Cell counting of cholera-labelled inputs was conducted using WholeBrain (Fürth et al., 2018; Wee and MacAskill, 2020). After acquiring the imaged sections and exporting them as 16-bit depth image files, images were manually assigned a bregma coordinate (AP -6.0 to $0.0 \mathrm{~mm}$ ) and processed using WholeBrain (Fürth et al., 2018) and custom cell counting routines written in $R$ (Wee and MacAskill, 2020). The workflow comprised of (1) segmentation of cells and brain section, (2) registration of the cells to the Allen Brain Atlas (ABA) and (3) analysis of anatomically registered cells. As tissue section damage impairs the automatic registration implemented on the WholeBrain platform, sections with poor registration were manually registered to the atlas plate using corresponding points to clear anatomical landmarks. Once all cells had been registered, the cell counts were further manually filtered from the dataset to remove false-positive cells (e.g. debris).

Each cell registered to a brain region was classified as belonging to an anatomically defined region as defined by the $A B A$ brain structure ontology. Information on the $A B A$ hierarchical ontology was scraped from the $A B A$ 
API (link: http://api.brain-map.org/api/v2/structure_graph_download/1.json) using custom Python routines. For quantification of input fractions, cells residing in different layers within the same structure, e.g. COAa1, COAa2 etc, were agglomerated across layers and subdivisions and counted as residing in one single region (e.g. COAa). Structures included as part of BA were: 'BLAa', 'BLAv', 'BLAp', 'BMAa', 'BMAp', 'LA', 'COAa', 'COApl', 'COApm', 'MEAa', 'MEAav', 'MEApd', 'MEApv', 'CEAc', 'CEAm', 'CEAl', 'PAA', 'PA'. For colocalization of VGAT+ and $\operatorname{CTX} \beta$ labelled neurons, images acquired as above were manually annotated with single and dual labelled neurons using Napari (napari contributors, 2019, doi:10.5281/zenodo.3555620). Whole brain distributions were visualised using the Brainrender package for python (Claudi et al., 2020).

\section{Electrophysiology}

\section{Slice preparation:}

Hippocampal recordings were studied in acute transverse slices. Mice were anaesthetized with a lethal dose of ketamine and xylazine, and perfused intracardially with ice-cold external solution containing (in mM): 190 sucrose, 25 glucose, $10 \mathrm{NaCl}, 25 \mathrm{NaHCO}_{3}, 1.2 \mathrm{NaH}_{2} \mathrm{PO}_{4}, 2.5 \mathrm{KCl}, 1 \mathrm{Na}^{+}$ascorbate, $2 \mathrm{Na}^{+}$pyruvate, $7 \mathrm{MgCl} 2$ and $0.5 \mathrm{CaCl}_{2}$, bubbled with $95 \% \mathrm{O}_{2}$ and $5 \% \mathrm{CO}_{2}$. Slices (400 $\mu \mathrm{m}$ thick) were cut in this solution and then transferred to artificial cerebrospinal fluid (aCSF) containing (in mM): $125 \mathrm{NaCl}, 22.5$ glucose, $25 \mathrm{NaHCO}_{3}, 1.25$ $\mathrm{NaH}_{2} \mathrm{PO}_{4}, 2.5 \mathrm{KCl}, 1 \mathrm{Na}^{+}$ascorbate, $3 \mathrm{Na}^{+}$pyruvate, $1 \mathrm{MgCl}_{2}$ and $2 \mathrm{CaCl}_{2}$, bubbled with $95 \% \mathrm{O}_{2}$ and $5 \% \mathrm{CO}_{2}$. After $30 \mathrm{~min}$ at $35{ }^{\circ} \mathrm{C}$, slices were stored for $30 \mathrm{~min}$ at $24{ }^{\circ} \mathrm{C}$. All experiments were conducted at room temperature $\left(22-24{ }^{\circ} \mathrm{C}\right)$. All chemicals were from Sigma, Hello Bio or Tocris.

\section{Whole-cell electrophysiology:}

Whole-cell recordings were made from hippocampal pyramidal neurons retrogradely labelled with retrobeads which were identified by their fluorescent cell bodies and targeted with Dodt contrast microscopy, as previously described (MacAskill et al., 2014; Sanchez-Bellot and MacAskill, 2020; Wee and MacAskill, 2020). For sequential paired recordings, neurons were identified within a single field of view at the same depth into the slice. The recording order was counterbalanced to avoid any potential complications that could be associated with rundown. For current clamp recordings, borosilicate recording pipettes (4-6 M 2 ) were filled with (in $\mathrm{mM}$ ): 135 K-gluconate, $10 \mathrm{HEPES}, 7 \mathrm{KCl}, 10 \mathrm{Na}$-phosphocreatine, $10 \mathrm{EGTA}, 4 \mathrm{MgATP}, 0.4 \mathrm{NaGTP}$. For voltage clamp experiments, three internals were used, First, in Figure 2, 3 and 4I-P, a Cs-gluconate based internal was used containing (in mM): 135 Gluconic acid, 10 HEPES, 7 KCl, 10 Na-phosphocreatine, 4 MgATP, 0.4 NaGTP, 10 TEA and 2 QX-314. Excitatory and inhibitory currents were electrically isolated by setting the holding potential at $-70 \mathrm{mV}$ (excitation) and $0 \mathrm{mV}$ (inhibition) and recording in the presence of APV. Experiments in Fig 4A,B,E-H were carried out using current clamp internal in APV in order to carry out post stimulation analysis of intrinsic properties of recorded interneurons. Finally, to record inhibitory currents at $-70 \mathrm{mV}$ in Fig.4C,D we used a high chloride internal (in mM): $135 \mathrm{CsCl}, 10 \mathrm{HEPES}, 7 \mathrm{KCl}, 10 \mathrm{Na}$-phosphocreatine, $10 \mathrm{EGTA}, 4 \mathrm{MgATP}, 0.3 \mathrm{NaGTP}$, 10 TEA and 2 QX-314. Recordings were made using a Multiclamp 700B amplifier, with electrical signals filtered at $4 \mathrm{kHz}$ and sampled at $10 \mathrm{kHz}$. 
bioRxiv preprint doi: https://doi.org/10.1101/2021.03.08.434367; this version posted March 8, 2021. The copyright holder for this preprint (which was not certified by peer review) is the author/funder, who has granted bioRxiv a license to display the preprint in perpetuity. It is made available under aCC-BY-NC-ND 4.0 International license.

Presynaptic glutamate release was triggered by illuminating $\mathrm{ChR} 2$ in the presynaptic terminals of long-range inputs into the slice, as previously described (Sanchez-Bellot and MacAskill, 2020; Wee and MacAskill, 2020). Wide-field illumination was achieved via a $40 \mathrm{x}$ objective with brief pulses of blue light from an LED centered at $470 \mathrm{~nm}$ (CoolLED pE-4000 / Thorlabs M470L4-C1, with appropriate excitation-emission filters). Light intensity was measured as $4-7 \mathrm{~mW}$ at the back aperture of the objective and was constant between all cell pairs.

\section{Electrophysiology data acquisition and analysis:}

Electrophysiology data were acquired using National Instruments boards and WinWCP (University of Strathclyde). Optical stimulation was via wide field irradiance with $473 \mathrm{~nm}$ LED light (CoolLED) as described above. Data was analysed using custom routines written in Python 3.6, imported using the neo package in python (Garcia et al., 2014). For connectivity analysis, a cell was considered connected if the average of lightinduced response was greater than 2 standard deviations above baseline. Amplitudes of responses were calculated as the average of a $2 \mathrm{~ms}$ window around the peak of the response. Current step data (Figure S2) was analysed using routines based around the eFEL package in python (Blue Brain Project).

\section{Integrate and fire model}

An integrate and fire model was constructed using the Brian2 package in python (Stimberg et al., 2019). 1000 vH-BA, vH-NAc and vH-PFC neurons were modelled interspersed with 80 interneurons (S.-H. Lee et al., 2014). Neurons were set to have a leak conductance, resting potential, spike threshold and membrane capacitance based on the literature and our current clamp recordings (Figure S2): leak conductance $5.5 \mathrm{nS}$; resting potential $-70 \mathrm{mV}$, spiking threshold $-35 \mathrm{mV}$, membrane capacitance $200 \mathrm{pF}$. Connectivity of the local vH circuit was based on our electrophysiology recordings. AMPA receptor connections were $1 \mathrm{nS}$ and were modelled with a tau of 5 ms. GABA receptor mediated connections were $3 \mathrm{nS}$ and modelled with a tau of $10 \mathrm{~ms}$. Feedback connectivity from each pyramidal neuron population was connected at a probability of 0.1 . The probability of connection of local interneurons to pyramidal neurons was based on Figure 4 , and was 0.8 for vH-NAc neurons, and 0.4 for vH-BA and vH-PFC neurons, each with a $3 \mathrm{nS}$ GABA conductance. To simulate excitatory BA input, neurons were supplied with 50,000 BA inputs timed as a Poisson distribution with an average rate of $10 \mathrm{~Hz}$. Each neuron was connected to this input with a probability of 0.1 , where the strength of the synaptic connection was randomly drawn from a normal distribution defined by our electrophysiology experiments in Figure 3 (vH-BA $0.3 \mathrm{nS}+$ 0.2 , vH-NAc $0.3 \mathrm{nS}+/-0.2$, vH-PFC $0.03 \mathrm{nS}+/-0.2$, interneurons $0.3 \mathrm{nS}+/-0.2$ ). To simulate BA inhibitory input, neurons were again supplied with 50,000 BA inputs timed as a Poisson distribution with an average rate of 10 $\mathrm{Hz}$, but the connection probability was calculated as a proportion of excitatory input, and varied across runs. As before the strength of each synaptic connection was randomly drawn from a normal distribution defined by our electrophysiology experiments in Figure 4 (vH-BA $0.3 \mathrm{nS}+/-0.2$, vH-NAc $0.08 \mathrm{nS}+/-0.2$, vH-PFC $0.03 \mathrm{nS}+/-$ 0.2 , interneurons $0.3 \mathrm{nS}+/-0.2$ ). Each simulation was run 5 times at each level of inhibitory connection strength, with the length of simulation $500 \mathrm{~ms}$ for each run. To investigate the influence of feedforward and feedback connection probability (Figure S4) we systematically altered these parameters for each run. Model output was analysed as total spikes produced by each neuronal population over the course of $500 \mathrm{~ms}$. 
bioRxiv preprint doi: https://doi.org/10.1101/2021.03.08.434367; this version posted March 8, 2021. The copyright holder for this preprint (which was not certified by peer review) is the author/funder, who has granted bioRxiv a license to display the preprint in perpetuity. It is made available under aCC-BY-NC-ND 4.0 International license.

\section{Behaviour}

After sufficient time for surgical recovery and viral expression (>4 weeks), mice underwent multiple rounds of habituation. Mice were habituated to the behavioural testing area in their home cage for $30 \mathrm{~min}$ prior to testing each day. Mice were habituated to handling for at least 3 days, followed by 1-2 days of habituation to the optical tether in their home cage for $10 \mathrm{~min}$.

\section{Real time place preference:}

Axon terminals were labelled as described above, and a $200 \mu \mathrm{m}$ optical fibre was implanted unilaterally $100 \mathrm{um}$ above the stimulation area $(\mathrm{vH})$. After habituation (above), behaviour was assessed using a real time place preference (RTPP) task. On Day 1 mice were exposed to the 3 chamber arena $(24 \mathrm{~cm} \mathrm{x} 16 \mathrm{~cm} \times 30 \mathrm{~cm})$ for 15 min without stimulation to allow habituation, and also to ensure no large side bias was present. The testing chamber was made out of black acrylic, was symmetrical and had no odour, visual or tactile cues to distinguish either side of the arena. The arena was thoroughly wiped down with $70 \%$ ethanol between each trial. Mice were excluded if they spend more than $80 \%$ of their time in one side of the chamber during this habitation session. On day 2, $20 \mathrm{~Hz}$ light stimulation was delivered via a $473 \mathrm{~nm}$ laser, coupled to a patch cord $(7-10 \mathrm{~mW}$ at the end of the patch cord) to activate ChR2 positive terminals. Real-time light delivery was based on the location of the mouse in the RTPP apparatus, where light stimulation occurred only when the mouse was in the light-paired side of the arena. The paired side was chosen randomly for each mouse and each session, thus in combination with the lack of explicit cues in the chamber, this assay represents acute place preference and not learned preference over sessions. Time spent in the light paired, and control side of the arena over the course of the 15 minute session was scored for each mouse using automated tracking analysis (Bonsai). For experiments involving pharmacogenetics (Fig 6,7), mice first underwent habituation and laser only trials as before, and data from control animals were used to replicate the original RTPP cohort (Figure 6A-C and 7A-C). Next, mice were given 1 - 2 daily s.c. injections of DMSO for habituation, before undergoing two further days of testing - first with DMSO as a control and with $10 \mathrm{mg} / \mathrm{kg}$ SalB the next day to avoid any spill over effects of the SalB injection. All injections were given 15 minutes prior to RTPP session. Control mice for optogenetics expressed GFP in BA. Control mice for KORD experiments consisted of a mixture of mice expressing smFP in $\mathrm{vH}^{\mathrm{NAc}}$ neurons and mice lacking expression in $\mathrm{vH}$, all of which received an injection of both DMSO and SalB. No differences were seen across the two conditions and so data were pooled.

\section{Statistics}

Summary data are reported throughout the figures either as boxplots, which show the median, 75th and 95th percentile as bar, box and whiskers respectively, or as line plots showing mean +/- s.e.m. Example physiology and imaging traces are represented as the median +/- s.e.m across experiments. Data were assessed using statistical tests described in the supplementary statistics summary, utilising the Pingouin statistical package for python (Vallat, 2018). Significance was defined as $P<0.05$, all tests were two sided. No statistical test was run to determine sample size a priori. The sample sizes we chose are similar to those used in previous publications. Animals were randomly assigned to a virus cohort (e.g. ChR2 versus GFP), and where possible the experimenter was blinded to each mouse's virus assignment when the experiment was performed. This was sometimes not possible due to e.g. the presence of the injection site in the recorded slice. 
bioRxiv preprint doi: https://doi.org/10.1101/2021.03.08.434367; this version posted March 8, 2021. The copyright holder for this preprint (which was not certified by peer review) is the author/funder, who has granted bioRxiv a license to display the preprint in perpetuity. It is made available under aCC-BY-NC-ND 4.0 International license.

\section{ACKNOWLEDGEMENTS}

We thank members of the MacAskill laboratory for helpful comments on the manuscript. A.F.M. was supported by a Sir Henry Dale Fellowship jointly funded by the Wellcome Trust and the Royal Society (grant number 109360/Z/15/Z) and by a UCL Excellence Fellowship. R.A. was supported by a King Fahad Medical City Studentship. R.W.S.W. was supported by a UCL Graduate Research Scholarship and a UCL Overseas Research Scholarship. K.M. was supported by the Wellcome Trust 4-year PhD in Neuroscience at UCL (grant number 215165/Z/18/Z).

\section{AUTHOR CONTRIBUTIONS}

Conceptualization, R.A. and A.F.M.; Methodology, R.A., R.W.S.W and A.F.M.; Investigation, R.A., R.W.S.W., K.M., A.R., D.R. and A.F.M.; Formal Analysis, R.A., R.W.S.W., A.R., and A.F.M.; Writing Original Draft, A.F.M.; Writing - Review \& Editing, R.A. and A.F.M.; Funding Acquisition, R.A. and A.F.M.; Supervision, A.F.M.

\section{DECLARATION OF INTERESTS}

The authors declare no competing interests.

\section{DATA AVAILABILITY}

The data that support the findings of this study are available from the corresponding author upon reasonable request. 


\section{REFERENCES}

Adhikari A, Lerner TN, Finkelstein J, Pak S, Jennings JH, Davidson TJ, Ferenczi E, Gunaydin LA, Mirzabekov JJ, Ye L, Kim S-Y, Lei A, Deisseroth K. 2015. Basomedial amygdala mediates top-down control of anxiety and fear. Nature 527:179-185. doi:10.1038/nature15698

Adhikari A, Topiwala MA, Gordon JA. 2010. Synchronized Activity between the Ventral Hippocampus and the Medial Prefrontal Cortex during Anxiety. Neuron 65:257-269. doi:10.1016/j.neuron.2009.12.002

Basu J, Zaremba JD, Cheung SK, Hitti FL, Zemelman BV, Losonczy A, Siegelbaum SA. 2016. Gating of hippocampal activity, plasticity, and memory by entorhinal cortex long-range inhibition. Science 351:aaa5694. doi:10.1126/science.aaa5694

Bazelot M, Bocchio M, Kasugai Y, Fischer D, Dodson PD, Ferraguti F, Capogna M. 2015. Hippocampal Theta Input to the Amygdala Shapes Feedforward Inhibition to Gate Heterosynaptic Plasticity. Neuron 87:1290-1303. doi:10.1016/j.neuron.2015.08.024

Beyeler A, Chang C-J, Silvestre M, Lévêque C, Namburi P, Wildes CP, Tye KM. 2018. Organization of Valence-Encoding and Projection-Defined Neurons in the Basolateral Amygdala. Cell Reports 22:905918. doi:10.1016/j.celrep.2017.12.097

Beyeler A, Namburi P, Glober GF, Simonnet C, Calhoon GG, Conyers GF, Luck R, Wildes CP, Tye KM. 2016. Divergent Routing of Positive and Negative Information from the Amygdala during Memory Retrieval. Neuron 90:348-361. doi:10.1016/j.neuron.2016.03.004

Britt JP, Benaliouad F, McDevitt RA, Stuber GD, Wise RA, Bonci A. 2012. Synaptic and Behavioral Profile of Multiple Glutamatergic Inputs to the Nucleus Accumbens. Neuron 76:790-803. doi:10.1016/j.neuron.2012.09.040

Cembrowski MS, Phillips MG, DiLisio SF, Shields BC, Winnubst J, Chandrashekar J, Bas E, Spruston N. 2018. Dissociable Structural and Functional Hippocampal Outputs via Distinct Subiculum Cell Classes.

Cell 173:1280-1292.e18. doi:10.1016/j.cell.2018.03.031

Chen PB, Hu RK, Wu YE, Pan L, Huang S, Micevych PE, Hong W. 2019. Sexually Dimorphic Control of Parenting Behavior by the Medial Amygdala. Cell 176:1206-1221.e18. doi:10.1016/j.cell.2019.01.024

Cho KKA, Hoch R, Lee AT, Patel T, Rubenstein JLR, Sohal VS. 2015. Gamma Rhythms Link Prefrontal Interneuron Dysfunction with Cognitive Inflexibility in Dlx5/6 +/- Mice. Neuron 85:1332-1343. doi:10.1016/j.neuron.2015.02.019

Ciocchi S, Herry C, Grenier F, Wolff SBE, Letzkus JJ, Vlachos I, Ehrlich I, Sprengel R, Deisseroth K, Stadler MB, Müller C, Lüthi A. 2010. Encoding of conditioned fear in central amygdala inhibitory circuits. Nature 468:277-282. doi:10.1038/nature09559

Ciocchi S, Passecker J, Malagon-Vina H, Mikus N, Klausberger T. 2015. Selective information routing by ventral hippocampal CA1 projection neurons. Science 348:560-563. doi:10.1126/science.aaa3245

Claudi F, Tyson AL, Petrucco L, Margrie TW, Portugues R, Branco T. 2020. Brainrender: a python-based software for visualizing anatomically registered data. Biorxiv 2020.02.23.961748. doi:10.1101/2020.02.23.961748

Dedic N, Kühne C, Jakovcevski M, Hartmann J, Genewsky AJ, Gomes KS, Anderzhanova E, Pöhlmann ML, Chang S, Kolarz A, Vogl AM, Dine J, Metzger MW, Schmid B, Almada RC, Ressler KJ, Wotjak CT, 
bioRxiv preprint doi: https://doi.org/10.1101/2021.03.08.434367; this version posted March 8,2021 . The copyright holder for this preprint (which was not certified by peer review) is the author/funder, who has granted bioRxiv a license to display the preprint in perpetuity. It is made available under aCC-BY-NC-ND 4.0 International license.

Grinevich V, Chen A, Schmidt MV, Wurst W, Refojo D, Deussing JM. 2018. Chronic CRH depletion from GABAergic, long-range projection neurons in the extended amygdala reduces dopamine release and increases anxiety. Nat Neurosci 21:803-807. doi:10.1038/s41593-018-0151-z

Dimidschstein J, Chen Q, Tremblay R, Rogers SL, Saldi G-A, Guo L, Xu Q, Liu R, Lu C, Chu J, Grimley JS, Krostag A-R, Kaykas A, Avery MC, Rashid MS, Baek M, Jacob AL, Smith GB, Wilson DE, Kosche G, Kruglikov I, Rusielewicz T, Kotak VC, Mowery TM, Anderson SA, Callaway EM, Dasen JS, Fitzpatrick D, Fossati V, Long MA, Noggle S, Reynolds JH, Sanes DH, Rudy B, Feng G, Fishell G. 2016. A viral strategy for targeting and manipulating interneurons across vertebrate species. Nat Neurosci 19:17431749. doi: $10.1038 / \mathrm{nn} .4430$

Fanselow MS, Dong H-W. 2010. Are the Dorsal and Ventral Hippocampus Functionally Distinct Structures? Neuron 65:7-19. doi:10.1016/j.neuron.2009.11.031

Felix-Ortiz AC, Beyeler A, Seo C, Leppla CA, Wildes CP, Tye KM. 2013. BLA to vHPC Inputs Modulate Anxiety-Related Behaviors. Neuron 79:658-664. doi:10.1016/j.neuron.2013.06.016

Felix-Ortiz AC, Tye KM. 2014. Amygdala Inputs to the Ventral Hippocampus Bidirectionally Modulate Social Behavior. J Neurosci 34:586-595. doi:10.1523/jneurosci.4257-13.2014

Fenno LE, Mattis J, Ramakrishnan C, Hyun M, Lee SY, He M, Tucciarone J, Selimbeyoglu A, Berndt A, Grosenick L, Zalocusky KA, Bernstein H, Swanson H, Perry C, Diester I, Boyce FM, Bass CE, Neve R, Huang ZJ, Deisseroth K. 2014. Targeting cells with single vectors using multiple-feature Boolean logic. Nat Methods 11:763-772. doi:10.1038/nmeth.2996

Fürth D, Vaissière T, Tzortzi O, Xuan Y, Märtin A, Lazaridis I, Spigolon G, Fisone G, Tomer R, Deisseroth K, Carlén M, Miller CA, Rumbaugh G, Meletis K. 2018. An interactive framework for whole-brain maps at cellular resolution. Nat Neurosci 21:139-149. doi:10.1038/s41593-017-0027-7

Garcia S, Guarino D, Jaillet F, Jennings T, Pröpper R, Rautenberg PL, Rodgers CC, Sobolev A, Wachtler T, Yger P, Davison AP. 2014. Neo: an object model for handling electrophysiology data in multiple formats. Front Neuroinform 8:10. doi:10.3389/fninf.2014.00010

Gergues MM, Han KJ, Choi HS, Brown B, Clausing KJ, Turner VS, Vainchtein ID, Molofsky AV, Kheirbek MA. 2020. Circuit and molecular architecture of a ventral hippocampal network. Nat Neurosci 23:14441452. doi:10.1038/s41593-020-0705-8

Gray JA, McNaughton N. 2003. The Neuropsychology of Anxiety, Oxford University Press. Oxford University Press.

Group PIN, Ascoli GA, Alonso-Nanclares L, Anderson SA, Barrionuevo G, Benavides-Piccione R, Burkhalter A, Buzsáki G, Cauli B, Defelipe J, Fairén A, Feldmeyer D, Fishell G, Fregnac Y, Freund TF, Gardner D, Gardner EP, Goldberg JH, Helmstaedter M, Hestrin S, Karube F, Kisvárday ZF, Lambolez B, Lewis DA, Marin O, Markram H, Muñoz A, Packer A, Petersen CCH, Rockland KS, Rossier J, Rudy B, Somogyi P, Staiger JF, Tamas G, Thomson AM, Toledo-Rodriguez M, Wang Y, West DC, Yuste R. 2008. Petilla terminology: nomenclature of features of GABAergic interneurons of the cerebral cortex. Nat Rev Neurosci 9:557-568. doi:10.1038/nrn2402

Gründemann J, Bitterman Y, Lu T, Krabbe S, Grewe BF, Schnitzer MJ, Lüthi A. 2019. Amygdala ensembles encode behavioral states. Science 364:eaav8736. doi:10.1126/science.aav8736 
bioRxiv preprint doi: https://doi.org/10.1101/2021.03.08.434367; this version posted March 8,2021 . The copyright holder for this preprint (which was not certified by peer review) is the author/funder, who has granted bioRxiv a license to display the preprint in perpetuity. It is made available under aCC-BY-NC-ND 4.0 International license.

Hitchcott PK, Phillips GD. 1997. Amygdala and hippocampus control dissociable aspects of drug-associated conditioned rewards. Psychopharmacology 131:187-195.

Jimenez JC, Su K, Goldberg AR, Luna VM, Biane JS, Ordek G, Zhou P, Ong SK, Wright MA, Zweifel L, Paninski L, Hen R, Kheirbek MA. 2018. Anxiety Cells in a Hippocampal-Hypothalamic Circuit. Neuron 97:670-683.e6. doi:10.1016/j.neuron.2018.01.016

Kim J, Pignatelli M, Xu S, Itohara S, Tonegawa S. 2016. Antagonistic negative and positive neurons of the basolateral amygdala. Nat Neurosci 19:1636-1646. doi:10.1038/nn.4414

Kim Y, Spruston N. 2012. Target-specific output patterns are predicted by the distribution of regular-spiking and bursting pyramidal neurons in the subiculum. Hippocampus 22:693-706. doi:10.1002/hipo.20931

Kjelstrup KG, Tuvnes FA, Steffenach H-A, Murison R, Moser El, Moser M-B. 2002. Reduced fear expression after lesions of the ventral hippocampus. Proc National Acad Sci 99:10825-10830. doi:10.1073/pnas.152112399

LeDoux JE. 2000. Emotion Circuits in the Brain. Annu Rev Neurosci 23:155-184. doi:10.1146/annurev.neuro.23.1.155

Lee AT, Vogt D, Rubenstein JL, Sohal VS. 2014. A Class of GABAergic Neurons in the Prefrontal Cortex Sends Long-Range Projections to the Nucleus Accumbens and Elicits Acute Avoidance Behavior. $J$ Neurosci 34:11519-11525. doi:10.1523/jneurosci.1157-14.2014

Lee S-H, Marchionni I, Bezaire M, Varga C, Danielson N, Lovett-Barron M, Losonczy A, Soltesz I. 2014. Parvalbumin-Positive Basket Cells Differentiate among Hippocampal Pyramidal Cells. Neuron 82:1129_ 1144. doi:10.1016/j.neuron.2014.03.034

LeGates TA, Kvarta MD, Tooley JR, Francis TC, Lobo MK, Creed MC, Thompson SM. 2018. Reward behaviour is regulated by the strength of hippocampus-nucleus accumbens synapses. Nature 564:258262. doi:10.1038/s41586-018-0740-8

Lutas A, Kucukdereli H, Alturkistani O, Carty C, Sugden AU, Fernando K, Diaz V, Flores-Maldonado V, Andermann ML. 2019. State-specific gating of salient cues by midbrain dopaminergic input to basal amygdala. Nat Neurosci 22:1820-1833. doi:10.1038/s41593-019-0506-0

MacAskill AF, Cassel JM, Carter AG. 2014. Cocaine exposure reorganizes cell type- and input-specific connectivity in the nucleus accumbens. Nat Neurosci 17:1198-1207. doi:10.1038/nn.3783

Malik R, Li Y, Schamiloglu S, Sohal VS. 2021. Top-down control of hippocampal signal-to-noise by prefrontal long-range inhibition. BioRxiv. doi:10.1101/2021.03.01.433441

Malvaez M, Shieh C, Murphy MD, Greenfield VY, Wassum KM. 2019. Distinct cortical-amygdala projections drive reward value encoding and retrieval. Nat Neurosci 22:762-769. doi:10.1038/s41593-019-0374-7

McDonald AJ, Mascagni F, Zaric V. 2012. Subpopulations of somatostatin-immunoreactive non-pyramidal neurons in the amygdala and adjacent external capsule project to the basal forebrain: evidence for the existence of GABAergic projection neurons in the cortical nuclei and basolateral nuclear complex. Front Neural Circuit 6:46. doi:10.3389/fncir.2012.00046

McDonald AJ, Mott DD. 2016. Functional neuroanatomy of amygdalohippocampal interconnections and their role in learning and memory. J Neurosci Res 95:797-820. doi:10.1002/jnr.23709

McDonald AJ, Zaric V. 2015. GABAergic somatostatin-immunoreactive neurons in the amygdala project to the entorhinal cortex. Neuroscience 290:227-242. doi:10.1016/j.neuroscience.2015.01.028 
bioRxiv preprint doi: https://doi.org/10.1101/2021.03.08.434367; this version posted March 8,2021 . The copyright holder for this preprint (which was not certified by peer review) is the author/funder, who has granted bioRxiv a license to display the preprint in perpetuity. It is made available under aCC-BY-NC-ND 4.0 International license.

McHugh SB, Deacon RMJ, Rawlins JNP, Bannerman DM. 2004. Amygdala and Ventral Hippocampus Contribute Differentially to Mechanisms of Fear and Anxiety. Behav Neurosci 118:63-78. doi:10.1037/0735-7044.118.1.63

Melzer S, Michael M, Caputi A, Eliava M, Fuchs EC, Whittington MA, Monyer H. 2012. Long-RangeProjecting GABAergic Neurons Modulate Inhibition in Hippocampus and Entorhinal Cortex. Science 335:1506-1510. doi:10.1126/science.1217139

Naber PA, Witter MP. 1998. Subicular efferents are organized mostly as parallel projections: a doublelabeling, retrograde-tracing study in the rat. The Journal of comparative neurology 393:284-297.

Namburi P, Beyeler A, Yorozu S, Calhoon GG, Halbert SA, Wichmann R, Holden SS, Mertens KL, Anahtar M, Felix-Ortiz AC, Wickersham IR, Gray JM, Tye KM. 2015. A circuit mechanism for differentiating positive and negative associations. Nature 520:675-678. doi:10.1038/nature14366

O'Keefe J, Nadel L. 1978. The Hippocampus as a Cognitive Map. Oxford University Press.

Okuyama T, Kitamura T, Roy DS, Itohara S, Tonegawa S. 2016. Ventral CA1 neurons store social memory. Science 353:1536-1541. doi:10.1126/science.aaf7003

Padilla-Coreano N, Bolkan SS, Pierce GM, Blackman DR, Hardin WD, Garcia-Garcia AL, Spellman TJ, Gordon JA. 2016. Direct Ventral Hippocampal-Prefrontal Input Is Required for Anxiety-Related Neural Activity and Behavior. Neuron 89:857-866. doi:10.1016/j.neuron.2016.01.011

Petrovich GD, Canteras NS, Swanson LW. 2001. Combinatorial amygdalar inputs to hippocampal domains and hypothalamic behavior systems. Brain research Brain research reviews 38:247-289.

Pi G, Gao D, Wu D, Wang Y, Lei H, Zeng W, Gao Y, Yu H, Xiong R, Jiang T, Li S, Wang X, Guo J, Zhang S, Yin T, He T, Ke D, Li R, Li H, Liu G, Yang X, Luo M, Zhang X, Yang Y, Wang J. 2020. Posterior basolateral amygdala to ventral hippocampal CA1 drives approach behaviour to exert an anxiolytic effect. Nat Commun 11:183. doi:10.1038/s41467-019-13919-3

Reed SJ, Lafferty CK, Mendoza JA, Yang AK, Davidson TJ, Grosenick L, Deisseroth K, Britt JP. 2018. Coordinated Reductions in Excitatory Input to the Nucleus Accumbens Underlie Food Consumption. Neuron 99:1260-1273.e4. doi:10.1016/j.neuron.2018.07.051

Richardson MP, Strange BA, Dolan RJ. 2004. Encoding of emotional memories depends on amygdala and hippocampus and their interactions. Nat Neurosci 7:278-285. doi:10.1038/nn1190

Sanchez-Bellot C, MacAskill AF. 2020. Push-pull regulation of exploratory behavior by two opposing hippocampal to prefrontal cortex pathways. BioRxiv. doi:10.1101/2019.12.18.880831

Schlesiger MI, Ruff T, MacLaren DAA, Barriuso-Ortega I, Saidov KM, Yen T-Y, Monyer H. 2021. Two septalentorhinal GABAergic projections differentially control coding properties of spatially tuned neurons in the medial entorhinal cortex. Cell Reports 34:108801. doi:10.1016/j.celrep.2021.108801

Selden NR, Everitt BJ, Jarrard LE, Robbins TW. 1991. Complementary roles for the amygdala and hippocampus in aversive conditioning to explicit and contextual cues. Neuroscience 42:335-350.

Seo D, Funderburk SC, Bhatti DL, Motard LE, Newbold D, Girven KS, McCall JG, Krashes M, Sparta DR, Bruchas MR. 2016. A GABAergic Projection from the Centromedial Nuclei of the Amygdala to Ventromedial Prefrontal Cortex Modulates Reward Behavior. J Neurosci 36:10831-10842. doi:10.1523/jneurosci.1164-16.2016 
Shemesh Y, Forkosh O, Mahn M, Anpilov S, Sztainberg Y, Manashirov S, Shlapobersky T, Elliott E, Tabouy L, Ezra G, Adler ES, Ben-Efraim YJ, Gil S, Kuperman Y, Haramati S, Dine J, Eder M, Deussing JM, Schneidman E, Yizhar O, Chen A. 2016. Ucn3 and CRF-R2 in the medial amygdala regulate complex social dynamics. Nat Neurosci 19:1489-1496. doi:10.1038/nn.4346

Sheth A, Berretta S, Lange N, Eichenbaum H. 2008. The amygdala modulates neuronal activation in the hippocampus in response to spatial novelty. Hippocampus 18:169-181. doi:10.1002/hipo.20380

Soltesz I, Losonczy A. 2018. CA1 pyramidal cell diversity enabling parallel information processing in the hippocampus. Nat Neurosci 21:484-493. doi:10.1038/s41593-018-0118-0

Spellman T, Rigotti M, Ahmari SE, Fusi S, Gogos JA, Gordon JA. 2015. Hippocampal-prefrontal input supports spatial encoding in working memory. Nature 522:309-314. doi:10.1038/nature14445

Stimberg M, Brette R, Goodman DF. 2019. Brian 2, an intuitive and efficient neural simulator. Elife 8:e47314. doi:10.7554/elife.47314

Strange BA, Witter MP, Lein ES, Moser El. 2014. Functional organization of the hippocampal longitudinal axis. Nat Rev Neurosci 15:655-669. doi:10.1038/nrn3785

Trouche S, Koren V, Doig NM, Ellender TJ, El-Gaby M, Lopes-dos-Santos V, Reeve HM, Perestenko PV, Garas FN, Magill PJ, Sharott A, Dupret D. 2019. A Hippocampus-Accumbens Tripartite Neuronal Motif Guides Appetitive Memory in Space. Cell 176:1393-1406.e16. doi:10.1016/j.cell.2018.12.037

Vallat R. 2018. Pingouin: statistics in Python. J Open Source Softw 3:1026. doi:10.21105/joss.01026

Vardy E, Robinson JE, Li C, Olsen RHJ, DiBerto JF, Giguere PM, Sassano FM, Huang X-P, Zhu H, Urban DJ, White KL, Rittiner JE, Crowley NA, Pleil KE, Mazzone CM, Mosier PD, Song J, Kash TL, Malanga CJ, Krashes MJ, Roth BL. 2015. A New DREADD Facilitates the Multiplexed Chemogenetic Interrogation of Behavior. Neuron 86:936-946. doi:10.1016/j.neuron.2015.03.065

Wee RWS, MacAskill AF. 2020. Biased Connectivity of Brain-wide Inputs to Ventral Subiculum Output Neurons. Cell Reports 30:3644-3654.e6. doi:10.1016/j.celrep.2020.02.093

Wikenheiser AM, Schoenbaum G. 2016. Over the river, through the woods: cognitive maps in the hippocampus and orbitofrontal cortex. Nat Rev Neurosci 17:513-523. doi:10.1038/nrn.2016.56

Yang Y, Wang J-Z. 2017. From Structure to Behavior in Basolateral Amygdala-Hippocampus Circuits. Front Neural Circuit 11:86. doi:10.3389/fncir.2017.00086 
bioRxiv preprint doi: https://doi.org/10.1101/2021.03 08.434367; this version posted March 8, 2021. The copyright holder for this preprint (which was not certified by peer review) is the author/funder, who has granted bioRxiv a license to display the preprint in perpetuity. It is made available under aCC-BY-NC-ND 4.0 International license.

2

\section{FIGURES}

A

亏

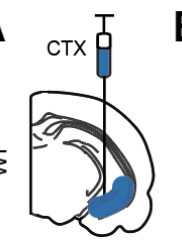

2 weeks \}

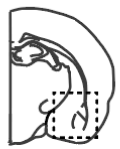

C
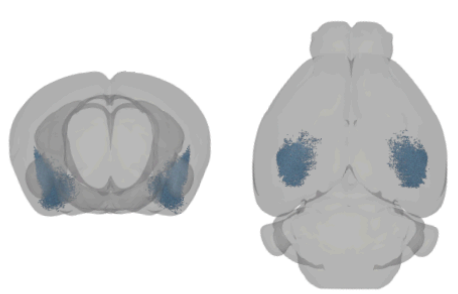
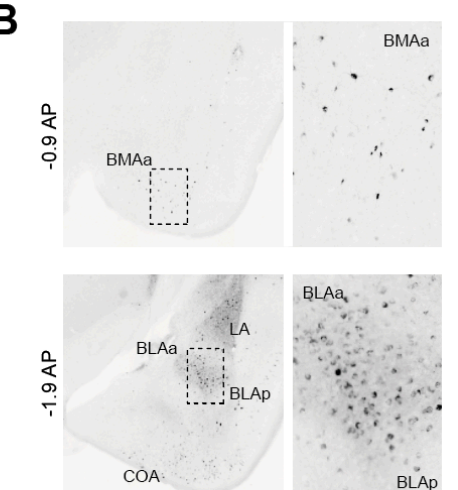

COA

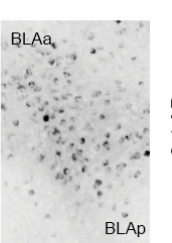

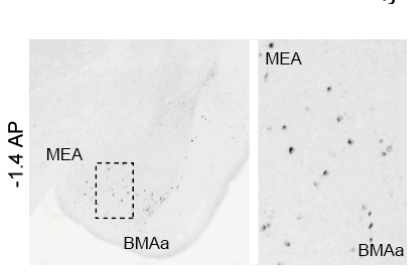

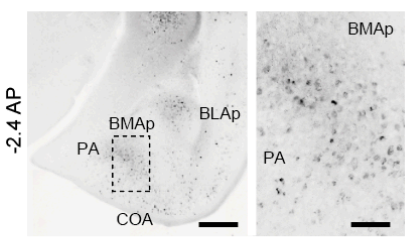

D

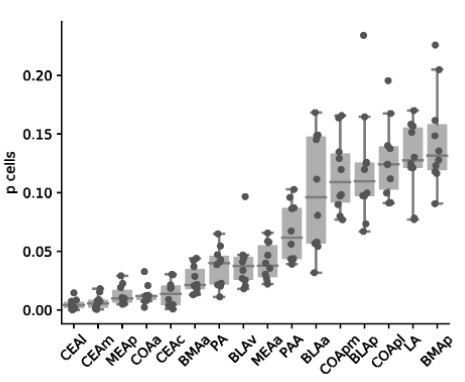

Figure 1 | Distribution of BA input to $\mathrm{vH}$.

A. Schematic of experiment. CTX $\beta$ was injected into $\mathrm{vH}, 2$ weeks later coronal slices of BA were examined for retrogradely labelled neurons.

B. Example slices showing widespread labelling throughout numerous BA nuclei. Scale bar $=500 \mathrm{um}, 100 \mathrm{um}$ (zoom).

C. Whole brain distribution of labelled BA neurons.

D. Summary showing proportion of labelled BA cells in each nuclei. 
bioRxiv preprint doi: https://doi.org/10.1101/2021.03.08.434367; this version posted March 8, 2021. The copyright holder for this preprint (which was not certified by peer review) is the author/funder, who has granted bioRxiv a license to display the preprint in perpetuity. It is made available under aCC-BY-NC-ND 4.0 International license.

A
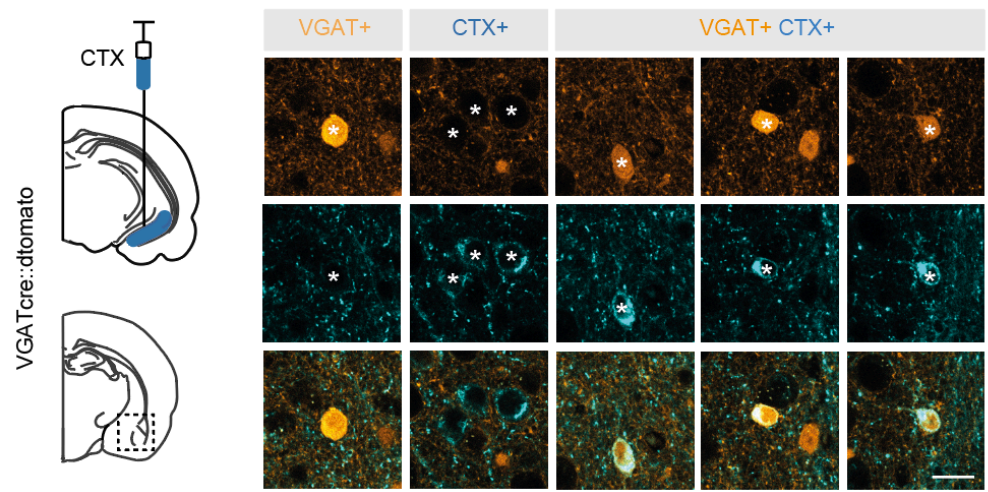

B

C
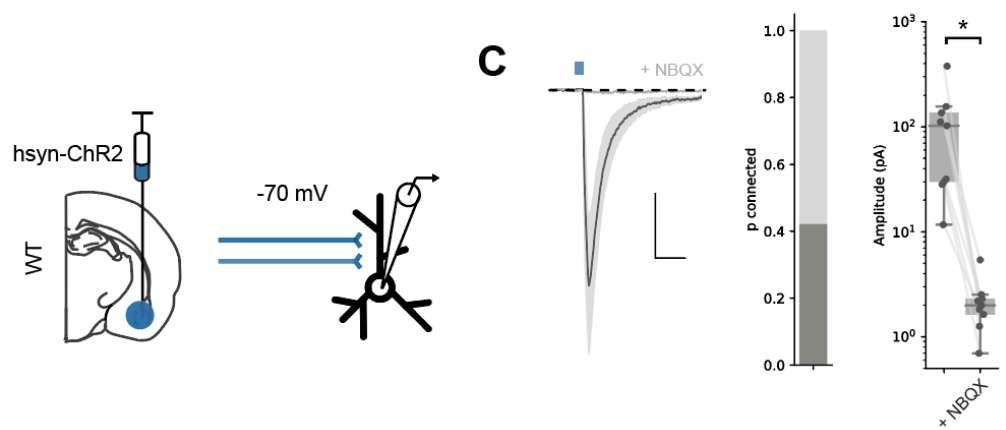

D

E
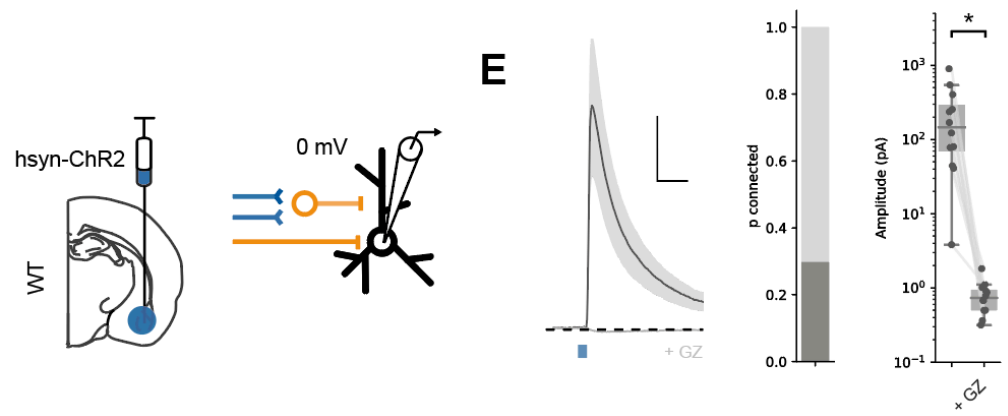

$\mathbf{F}$

G
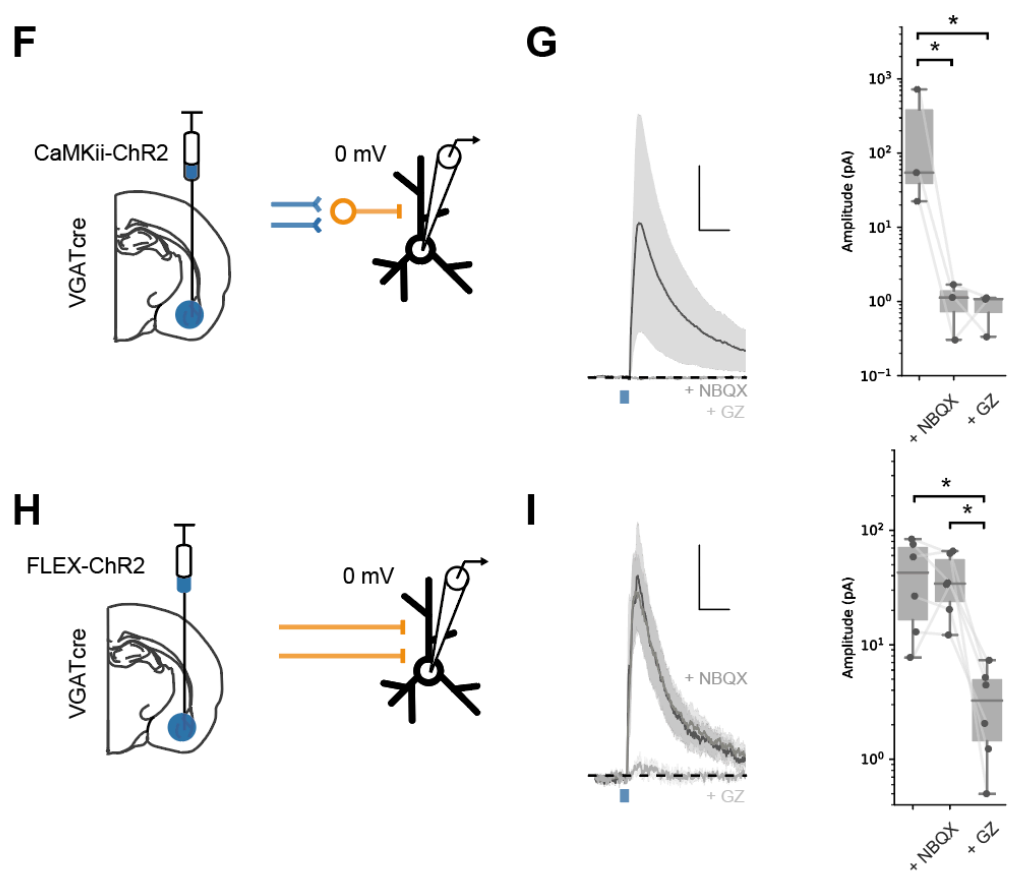
bioRxiv preprint doi: https://doi.org/10.1101/2021.03.08.434367; this version posted March 8, 2021. The copyright holder for this preprint (which was not certified by peer review) is the author/funder, who has granted bioRxiv a license to display the preprint in perpetuity. It is made available under aCC-BY-NC-ND 4.0 International license.

\section{Figure 2 | BA input to $\mathrm{vH}$ is both excitatory and inhibitory.}

A. CTX $\beta$ injection in $v H$ in a vGAT::cre::dtomato mouse line reveals inhibitory neurons (vGAT+), putative excitatory neurons that project to $\mathrm{vH}(\mathrm{CTX}+)$ and inhibitory neurons that project to $\mathrm{vH}(\mathrm{vGAT}+\mathrm{CTX}+)$. Scale bar $=20 \mathrm{um}$.

B. Schematic showing experimental setup. ChR2 was expressed using the pan-neuronal synapsin promoter using an AAV injection in BA. After allowing for expression, whole cell recordings were performed in voltage clamp at $-70 \mathrm{mV}$ in vH.

C. Brief pulses of blue light evoke excitatory currents that are blocked by the AMPA receptor antagonist NBQX. Left, Average current trace pre and post NBQX. Middle, proportion of recorded cells connected (with time-locked response to light). Right, Amplitude before and after NBQX. Note log scale. NBQX blocks excitatory currents evoked by BA input. Scale bar $=50 \mathrm{pA}, 10 \mathrm{~ms}$.

D, E. As B,C but for voltage clamp at $0 \mathrm{mV}$ before and after the GABA receptor antagonist gabazine. Gabazine blocks inhibitory currents evoked by BA input. Scale bar $=50 \mathrm{pA}, 10 \mathrm{~ms}$.

F. Feedforward inhibition isolated using ChR2 expression under the CaMKii promoter.

G. Brief pulses of blue light evoked inhibitory currents at $0 \mathrm{mV}$ that are blocked by the AMPA receptor antagonist NBQX. Left, Average current trace pre and post NBQX and GZ. Right, Amplitude before and after NBQX and GZ. Note log scale. NBQX blocks inhibitory currents evoked by CaMKii BA input, indicating it is solely feedforward. Scale bar $=50 \mathrm{pA}, 10 \mathrm{~ms}$.

H, I. As for F,G but direct inhibitory input isolated using ChR2 expression only in vGAT+ BA neurons. NBQX has no effect on direct inhibitory connection, while it is blocked by GZ, indicating it is a direct, long range inhibitory connection. Scale bar $=15 \mathrm{pA}, 10 \mathrm{~ms}$. 
bioRxiv preprint doi: https://doi.org/10.1101/2021.03.08.434367; this version posted March 8, 2021. The copyright holder for this preprint (which was not certified by peer review) is the author/funder, who has granted bioRxiv a license to display the preprint in perpetuity. It is made available under aCC-BY-NC-ND 4.0 International license.

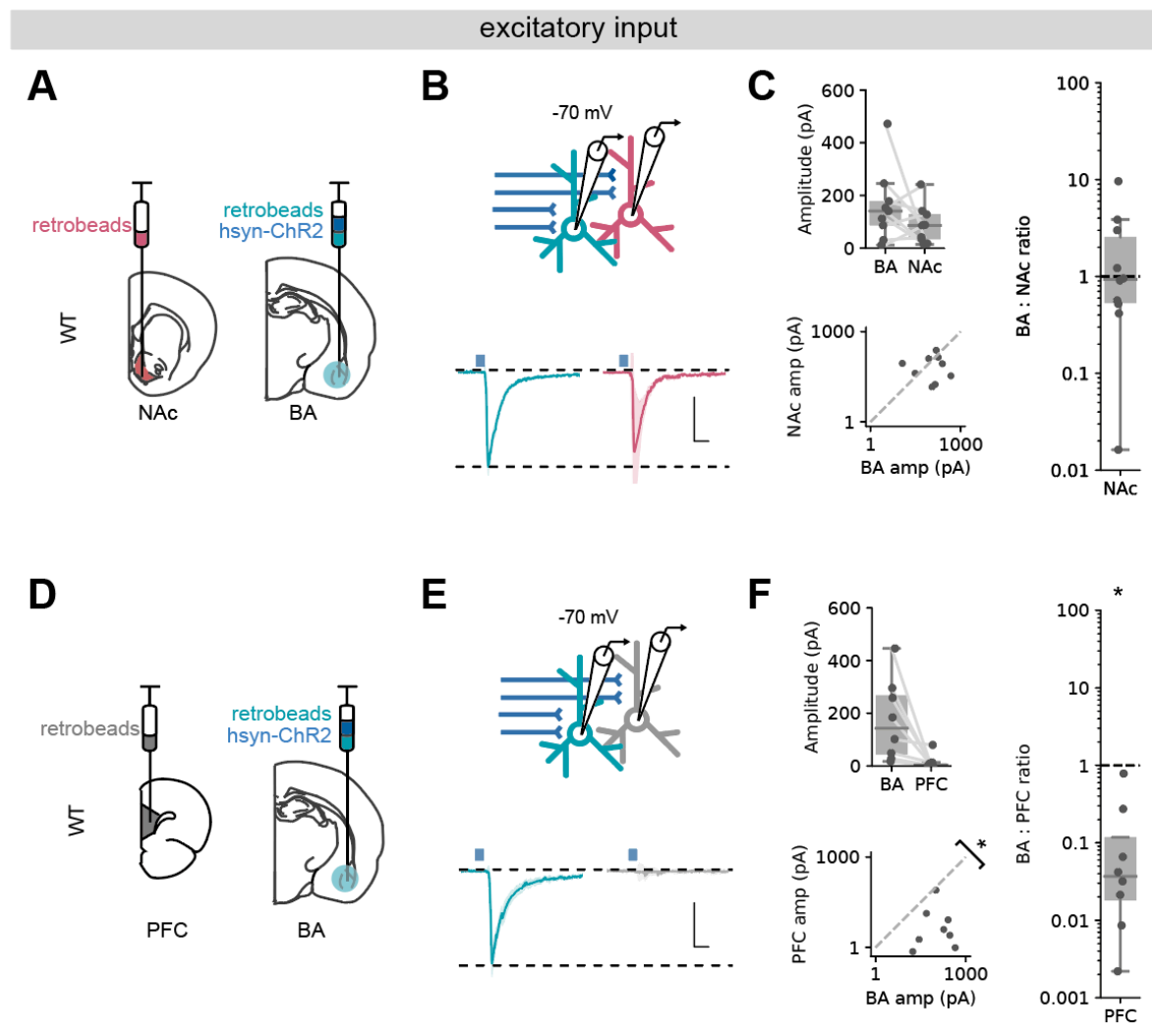

inhibitory input

$\mathbf{G}$

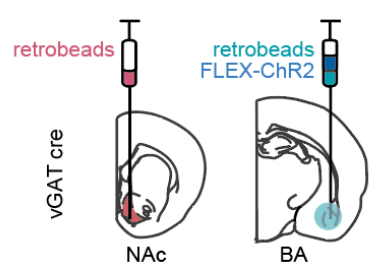

H

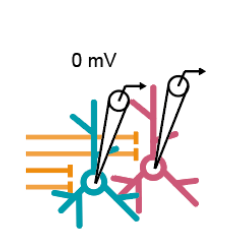

I

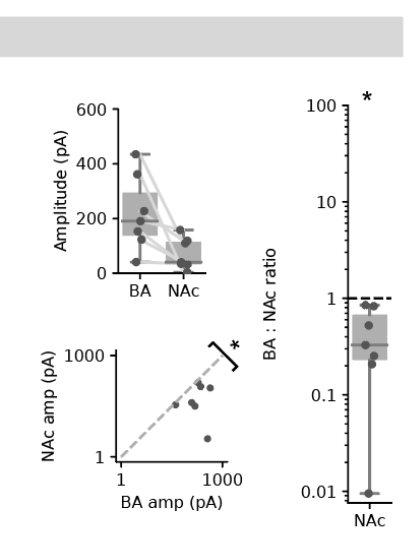

L

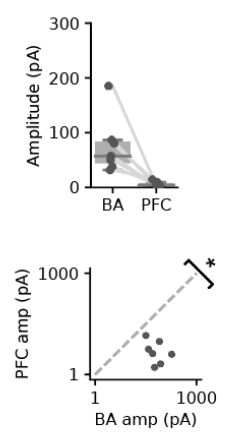

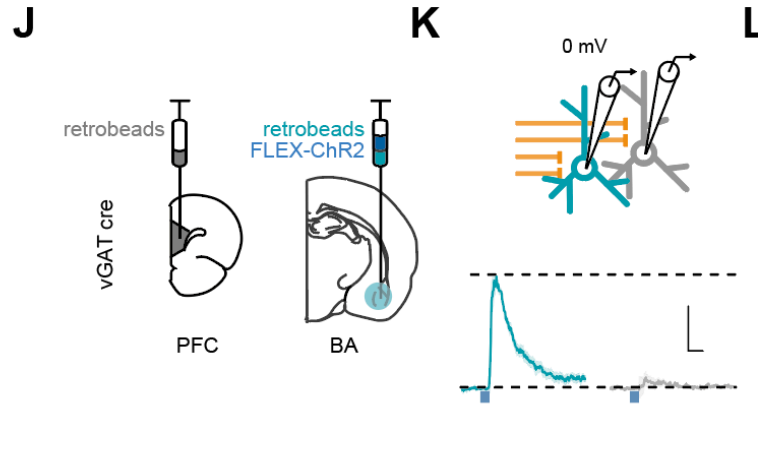

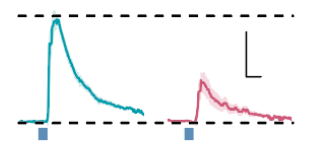

K

\section{J}

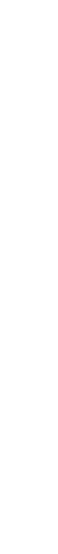


bioRxiv preprint doi: https://doi.org/10.1101/2021.03.08.434367; this version posted March 8, 2021. The copyright holder for this preprint (which was not certified by peer review) is the author/funder, who has granted bioRxiv a license to display the preprint in perpetuity. It is made available under aCC-BY-NC-ND 4.0 International license.

\section{Figure 3 | Excitatory and inhibitory BA input differentially targets vH output populations.}

A. Schematic of experiment $\mathrm{vH}^{\mathrm{NAC}}$ and $\mathrm{vH}^{\mathrm{BA}}$ neurons were labelled with retrobead injections, and $\mathrm{ChR} 2$ was expressed pan neuronally in BA.

B. Paired, fluorescently targeted recordings from neurons in each pathway and recording of light evoked currents. Top, recording setup. Bottom, average light evoked currents in $\mathrm{vH}^{\mathrm{BA}}\left(\right.$ green) and $\mathrm{vH}^{\mathrm{NAc}}($ red $)$ neurons. Scale bar $=0.5 \mathrm{vH}^{\mathrm{BA}}$ response, $10 \mathrm{~ms}$.

C. Summary of amplitude of light evoked $\mathrm{BA}$ input in pairs of $\mathrm{vH}^{\mathrm{NAc}}$ and $\mathrm{vH}^{\mathrm{BA}}$ neurons (top). When displayed as a scatter plot (bottom), or as the ratio of $\mathrm{vH}^{\mathrm{NAC}}$ : $\mathrm{vH}^{\mathrm{BA}}$ (right), the amplitudes cluster on the line of unity, indicating these population shave equal input. Note log axis.

D-F. As A-C but for pairs of $\mathrm{vH}^{\mathrm{BA}}$ and $\mathrm{vH}^{\mathrm{PFC}}$ neurons. Note when displayed as a scatter and a ratio of $\mathrm{vH}^{\mathrm{PFC}}: \mathrm{vH}^{\mathrm{BA}}$ amplitudes are below the line of unity, indicating input preferentially innervates $\mathrm{vH}^{\mathrm{BA}}$ neurons.

G-L. As A-F but for inhibitory input from BA isolated by expressing FLEX ChR2 in a vGAT::Cre line. Note when displayed as a scatter and a ratio, both $\mathrm{vH}^{\mathrm{PFC}}$ and $\mathrm{vH}^{\mathrm{NAC}}$ amplitudes are below the line of unity, indicating inhibitory input preferentially innervates $\mathrm{vH}^{\mathrm{BA}}$ neurons in both cases. Scale bar $=0.5 \mathrm{vH}^{\mathrm{BA}}$ response, $10 \mathrm{~ms}$. 
bioRxiv preprint doi: https://doi.org/10.1101/2021.03.08.434367; this version posted March 8, 2021. The copyright holder for this preprint

(which was not certified by peer review) is the author/funder, who has granted bioRxiv a license to display the preprint in perpetuity. It is made available under aCC-BY-NC-ND 4.0 International license.

feedforward BA input onto $\mathrm{vH}$ inhibitory neurons

A

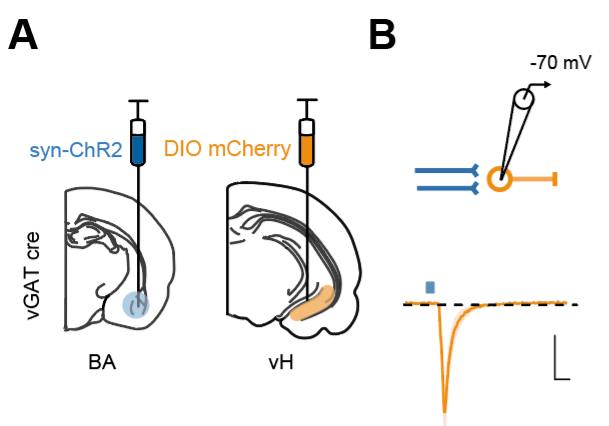

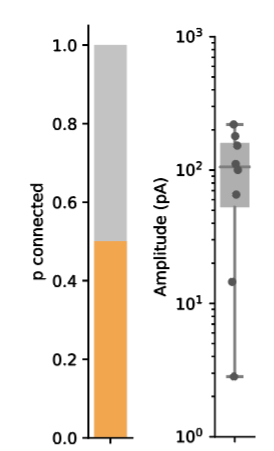

C

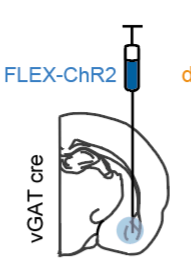

BA
D

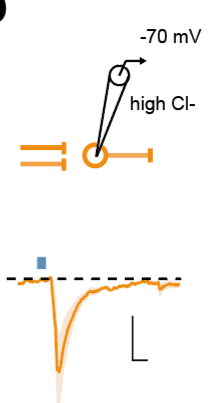

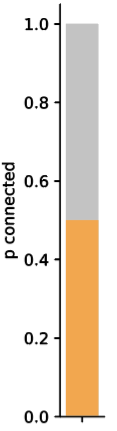

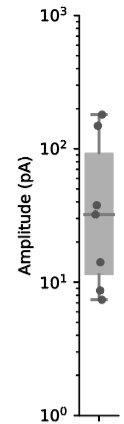

feedback input onto $\mathrm{vH}$ inhibitory neurons
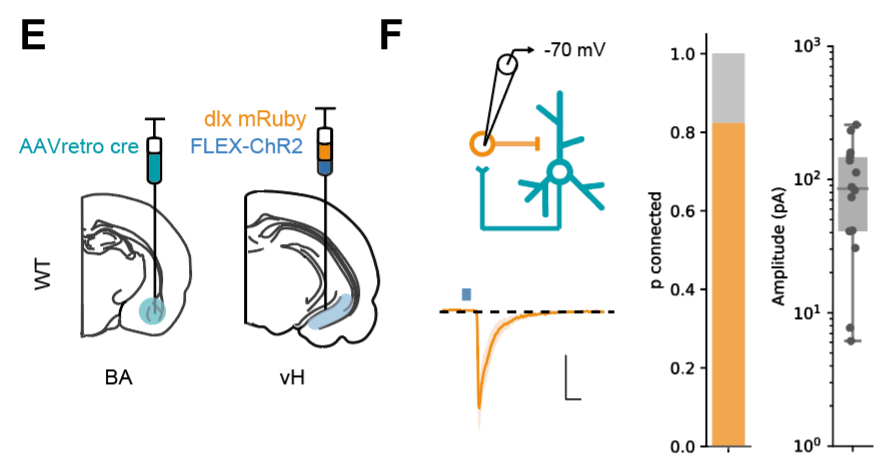

G
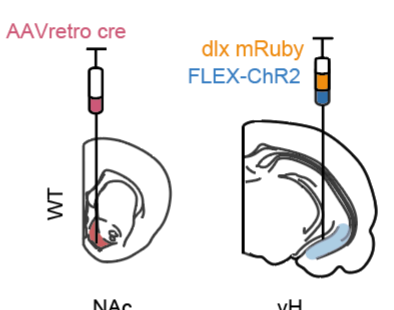

H
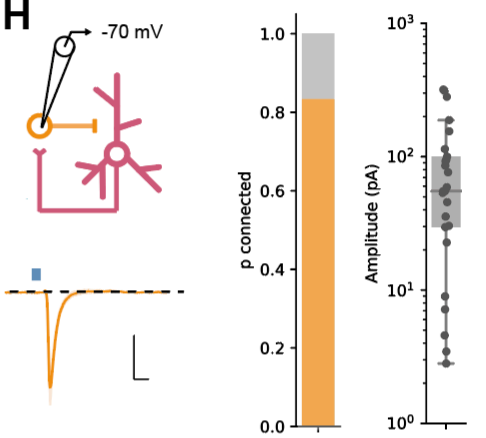

local inhibitory input onto $\mathrm{vH}$ output neurons

\section{I}

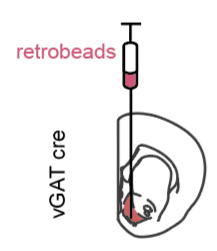

NAc

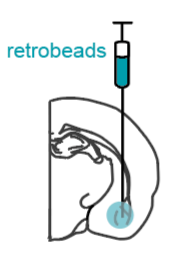

BA

\section{J}
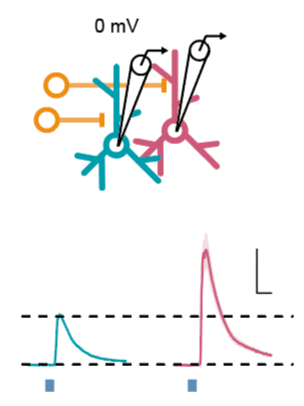

K
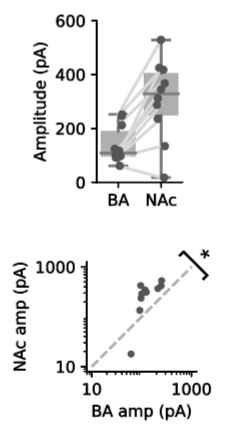

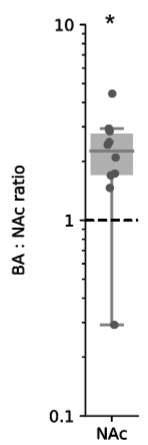

feedforward inhibitory input onto $\mathrm{vH}$ output neurons

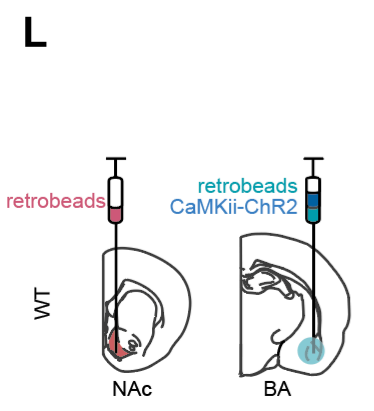

M
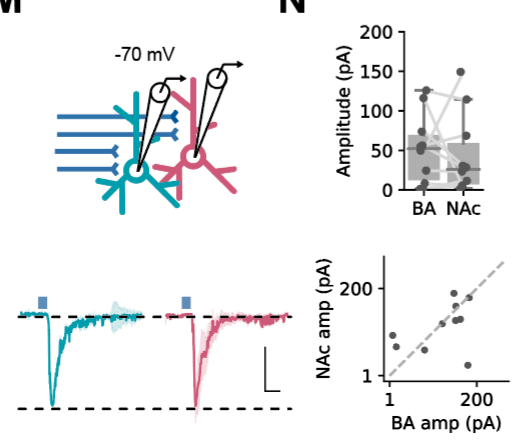

N
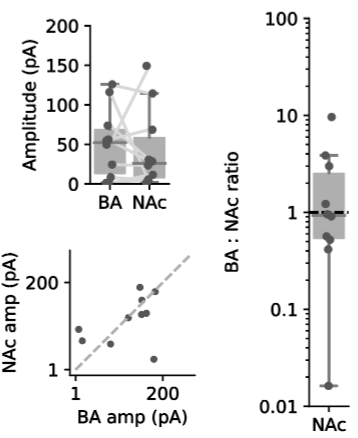

o

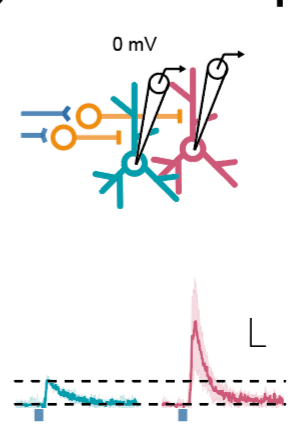

P

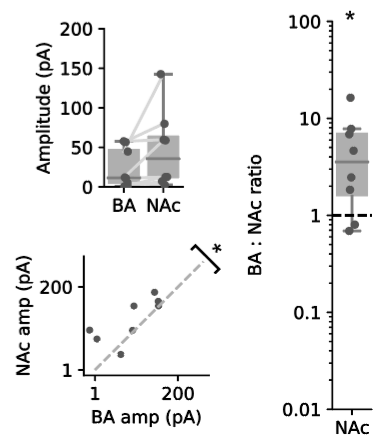


bioRxiv preprint doi: https://doi.org/10.1101/2021.03.08.434367; this version posted March 8, 2021. The copyright holder for this preprint (which was not certified by peer review) is the author/funder, who has granted bioRxiv a license to display the preprint in perpetuity. It is made available under aCC-BY-NC-ND 4.0 International license.

Figure 4 | BA input interacts with local inhibitory circuitry that is biased towards $\mathrm{vH}^{\mathrm{NAc}}$ neurons.

A. schematic of experiment. ChR2 was expressed in BA, and DIO mCherry was expressed in vH in vGAT:cre mice to label local interneurons.

B. Left, Recording configuration to record excitatory connectivity at $-70 \mathrm{mV}$ (top). Average light evoked current in interneurons in $\mathrm{vH}$. Scale bar $=50 \mathrm{pA}, 10 \mathrm{~ms}$. Right, Summary of probability of connection (left) and amplitude of connected currents (right).

C,D. As A, B but for inhibitory input isolated using FLEX ChR2 expression in vGAT:cre mice as before. Note recordings were performed in high $\mathrm{Cl}-$, so inward currents were measured at $-70 \mathrm{mV}$.

E. Experimental setup for investigating feedback connectivity from $\mathrm{vH}^{\mathrm{BA}}$ neurons. AAVretro was injected into $\mathrm{BA}$, and FLEX ChR2 and dlx-mRuby into $\mathrm{vH}$ to allow recordings from $\mathrm{dl} x+$ interneurons, and measurement of light evoked currents from $\mathrm{vH}^{\mathrm{BA}}$ activation.

F. Left, Recording configuration to record excitatory connectivity at $-70 \mathrm{mV}($ top $)$. Average light evoked current in dlx+interneurons in $\mathrm{vH}$. Right, Summary of probability of connection (left) and amplitude of connected currents (right).

G,H. As E,F but for feedback input from $\mathrm{vH}^{\mathrm{NAC}}$ neurons.

I. Schematic of experiment, $\mathrm{vH}^{\mathrm{NAc}}$ and $\mathrm{vH}^{\mathrm{BA}}$ cells were labelled with injections of retrobeads, while $\mathrm{ChR} 2$ was expressed in $\mathrm{vH}$ interneurons using FLEX ChR2 in a vGAT::cre mouse.

J. Paired, fluorescently targeted recordings from neurons in each pathway at $0 \mathrm{mV}$ and recording of light evoked currents. Top, recording setup. Bottom, average light evoked currents in $\mathrm{vH}^{\mathrm{BA}}($ green $)$ and $\mathrm{vH}^{\mathrm{NAc}}($ red $)$ neurons. Scale bar $=1 \mathrm{vH}-\mathrm{BA}$ response, 10 ms.

K. Summary of amplitude of light evoked $\mathrm{BA}$ input in pairs of $\mathrm{vH}^{\mathrm{NAc}}$ and $\mathrm{vH}^{\mathrm{BA}}$ neurons (top). When displayed as a scatter plot (bottom), or as the ratio of $\mathrm{vH}^{\mathrm{NAc}}: \mathrm{vH}^{\mathrm{BA}}$ (right), the amplitudes cluster above the line of unity, indicating that local inhibition preferentially innervates $\mathrm{vH}^{\mathrm{NAc}}$ neurons. Note log axis.

L-N. as I, J but for CaMKii input recorded at $-70 \mathrm{mV}$. Note as in Figure 3 there is equal input onto both populations. Scale bar $=0.5$ $\mathrm{vH}^{\mathrm{BA}}$ response, $10 \mathrm{~ms}$.

$\mathbf{O}, \mathbf{P}$. as in $\mathbf{M}, \mathbf{N}$ but recording at $0 \mathrm{mV}$ to isolate feedforward inhibition. Note that the amplitudes cluster above the line of unity, indicating that feedforward inhibition preferentially innervates $\mathrm{vH}^{\mathrm{NAc}}$ neurons. Scale bar $=1 \mathrm{vH}-\mathrm{BA}$ response, $10 \mathrm{~ms}$. 
bioRxiv preprint doi: https://doi.org/10.1101/2021.03.08.434367; this version posted March 8, 2021. The copyright holder for this preprint (which was not certified by peer review) is the author/funder, who has granted bioRxiv a license to display the preprint in perpetuity. It is made available under aCC-BY-NC-ND 4.0 International license.
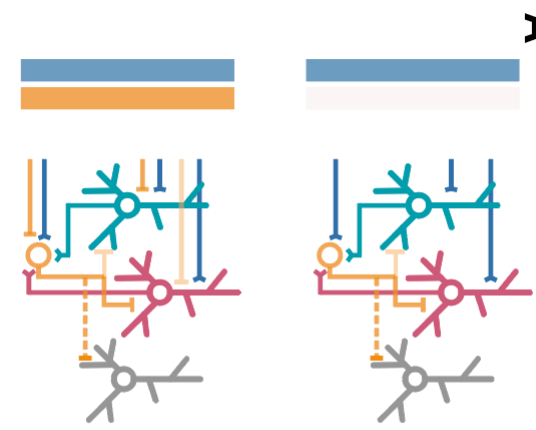

w

VH-PFC $\quad$ VH-NAC $\quad$ HH-BA

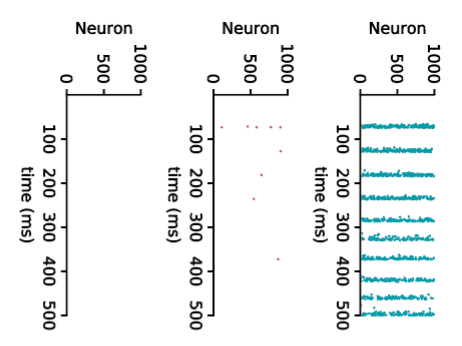



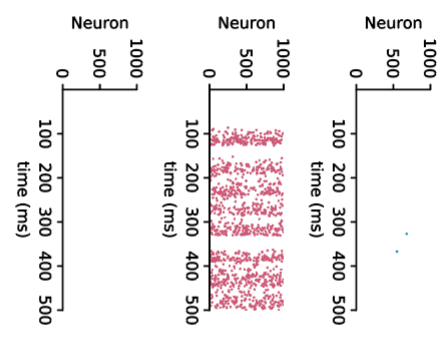

$\Omega$

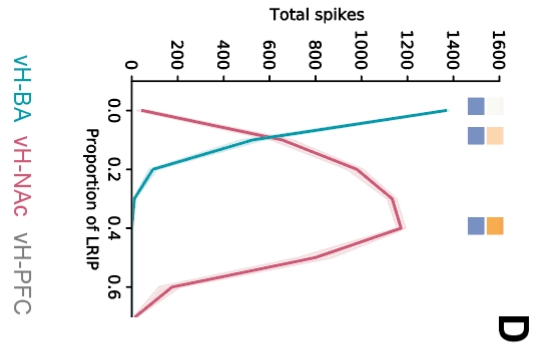

Total spikes

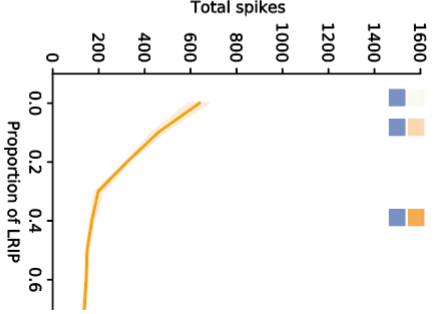


bioRxiv preprint doi: https://doi.org/10.1101/2021.03.08.434367; this version posted March 8, 2021. The copyright holder for this preprint (which was not certified by peer review) is the author/funder, who has granted bioRxiv a license to display the preprint in perpetuity. It is made available under aCC-BY-NC-ND 4.0 International license.

\section{Figure 5 | Co-activation of inhibitory and excitatory input switches $\mathrm{vH}$ activity from $\mathrm{vH}^{\mathrm{BA}}$ to $\mathrm{vH}^{\mathrm{NAc}}$}

A. Schematic of integrate and fire model. Three populations of projection neurons $\left(\mathrm{vH}^{\mathrm{NAc}}, \mathrm{red} ; \mathrm{vH}^{\mathrm{BA}}\right.$, green; $\mathrm{vH}^{\mathrm{PFC}}$, grey) and local interneurons (orange) are innervated by excitatory (blue, top) as well as inhibitory (orange, bottom) BA input. Connectivity is defined from results in previous figures.

B. Increasing the proportion of inhibitory relative to excitatory BA input has opposite effects on $\mathrm{vH}^{\mathrm{BA}}$ and $\mathrm{vH} \mathrm{HAc}^{\mathrm{NAc}}$ spiking. Each graph shows a raster of spiking for each neuron across a $500 \mathrm{~ms}$ period. Note high $\mathrm{vH}^{\mathrm{BA}}$ spiking with no inhibitory input, and high $\mathrm{vH}^{\mathrm{NAc}}$ spiking with high inhibitory input. $\mathrm{vH}^{\mathrm{PFC}}$ neurons never fire as they are not innervated by $\mathrm{BA}$, and only receive background input.

C. Summary of pyramidal neuron activity. With increasing inhibitory input, activity shifted from $\mathrm{vH}^{\mathrm{BA}}$ to $\mathrm{vH}^{\mathrm{NAc}}$ neurons. Markers indicate proportions plotted in $\mathbf{B}$.

D. Long range inhibition reduces local interneuron firing, removing preferential feedback inhibition onto $\mathrm{vH}^{\mathrm{NAc}}$ neurons, allowing them to fire. 
bioRxiv preprint doi: https://doi.org/10.1101/2021.03.08.434367; this version posted March 8, 2021. The copyright holder for this preprint

(which was not certified by peer review) is the author/funder, who has granted bioRxiv a license to display the preprint in perpetuity. It is made available under aCC-BY-NC-ND 4.0 International license.

A

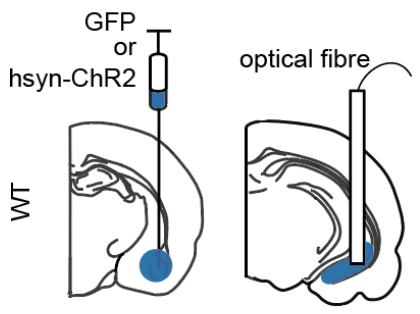

D
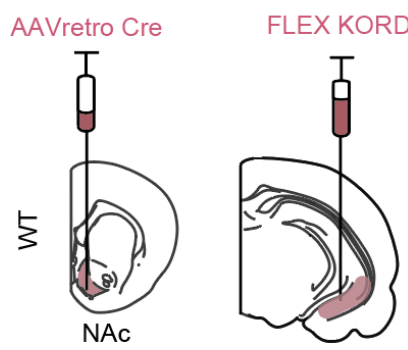

B

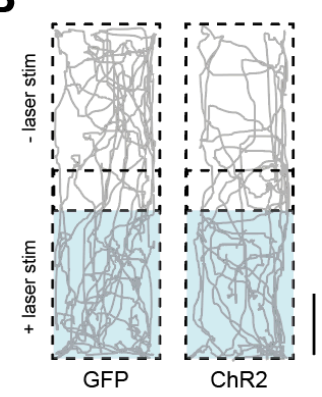

$\mathbf{E}$

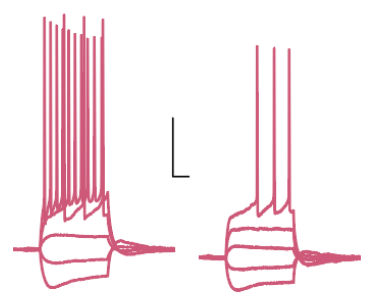

C

$\mathbf{F}$
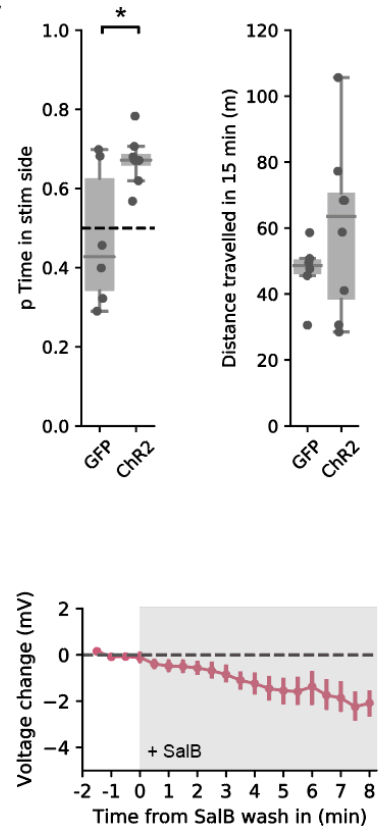

G


H

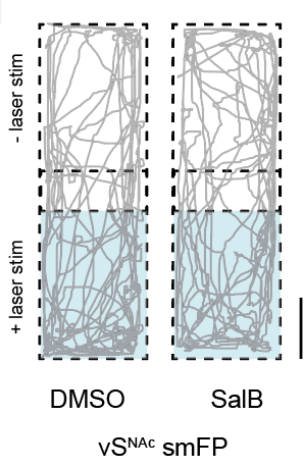

J

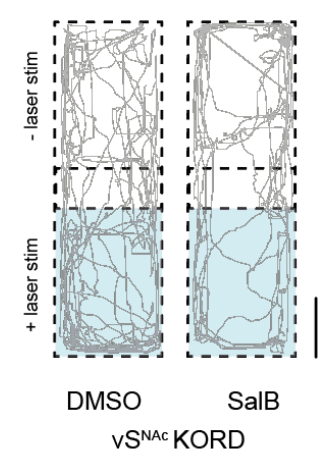

\section{I}
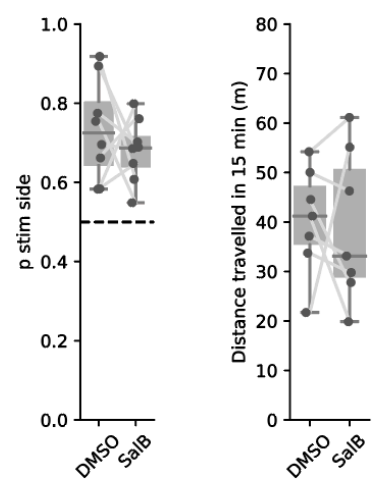

K

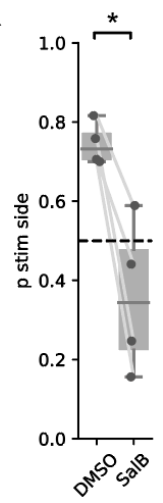

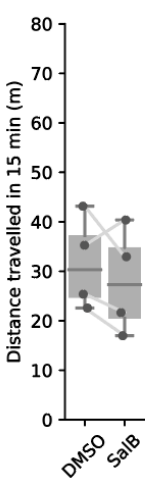


bioRxiv preprint doi: https://doi.org/10.1101/2021.03 08.434367; this version posted March 8, 2021. The copyright holder for this preprint (which was not certified by peer review) is the author/funder, who has granted bioRxiv a license to display the preprint in perpetuity. It is made available under aCC-BY-NC-ND 4.0 International license.

\section{Figure 6 | BA input supports real time place preference dependent on $\mathrm{vH}^{\mathrm{NAC}}$ neurons.}

A. Schematic of experiment. GFP or pan-neuronal ChR2 were expressed in BA, and an optic fibre implanted in $\mathrm{vH}$.

B. Real time place preference (RTPP) assay. One side of a chamber was paired with $20 \mathrm{~Hz}$ blue light stimulation. Example trajectories of GFP (left) and ChR2 (right) expressing animals over the 15 min RTPP session. Note increased occupancy of lightpaired (stim) side in ChR2 animals. Scale bar $=15 \mathrm{~cm}$.

C. Summary of RTPP. Left, Proportion of time spent on stim side (left) and total distance travelled (right) in GFP and ChR2 animals. Note consistent preference for stim side in ChR2 animals.

D. Strategy to express $\mathrm{KORD}$ in $\mathrm{vH}^{\mathrm{NAc}}$ neurons.

E,F. Bath application of SalB (100 nm) hyperpolarises KORD expressing vH $\mathrm{H}^{\mathrm{NAC}}$ neurons, and reduces AP firing. See Figure S4 for full quantification. Scale bar $=30 \mathrm{mV}, 100 \mathrm{~ms}$.

G. Schematic of strategy to inhibit $\mathrm{vH}^{\mathrm{NAc}}$ neurons during BA input driven RTPP.

H,I. As B,C but comparing the effect of either DMSO (vehicle) or SalB (KORD agonist) injections 15 mins before testing in control mice. Note consistent RTPP in both conditions indicating no effect of SalB in control mice.

J,K. As $\mathbf{H}, \mathbf{I}$, but in mice expressing KORD in $\mathrm{vH}^{\mathrm{NAc}}$ neurons. Note loss of RTPP in SalB injected mice compared to controls. 
bioRxiv preprint doi: https://doi.org/10.1101/2021.03.08.434367; this version posted March 8, 2021. The copyright holder for this preprint

A
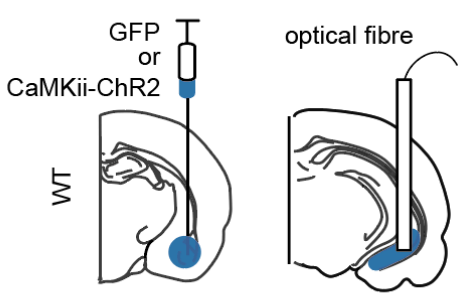

与

D AAVretro Cre

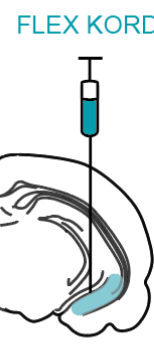

BA

\section{G}

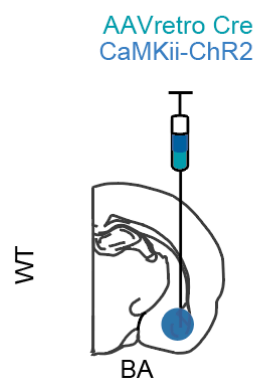

FLEX smFP

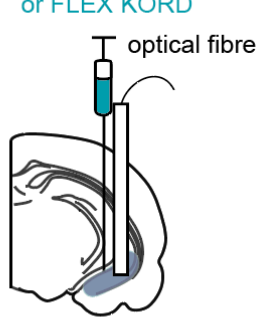

B

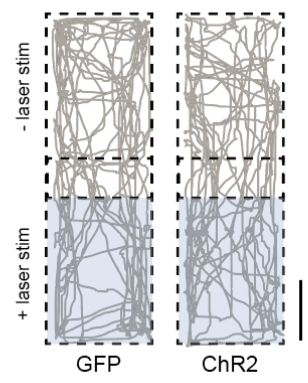

$\mathbf{E}$

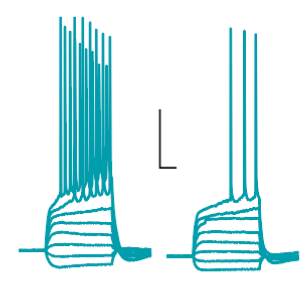

H

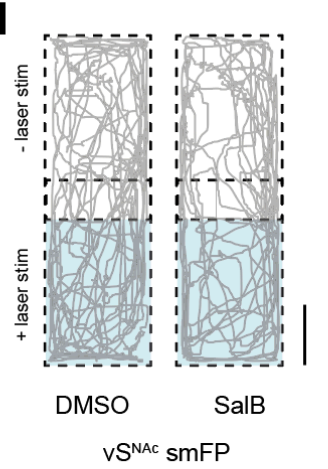

J

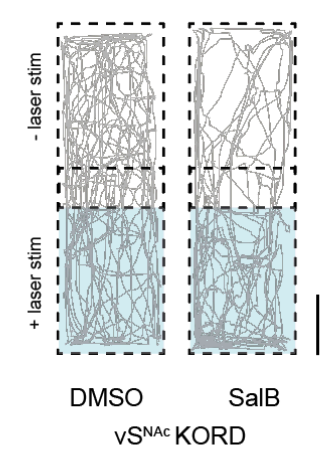

I
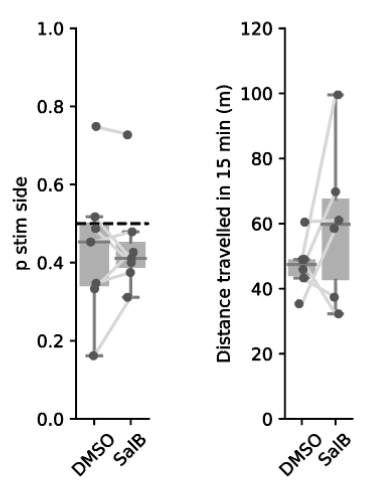

C

F
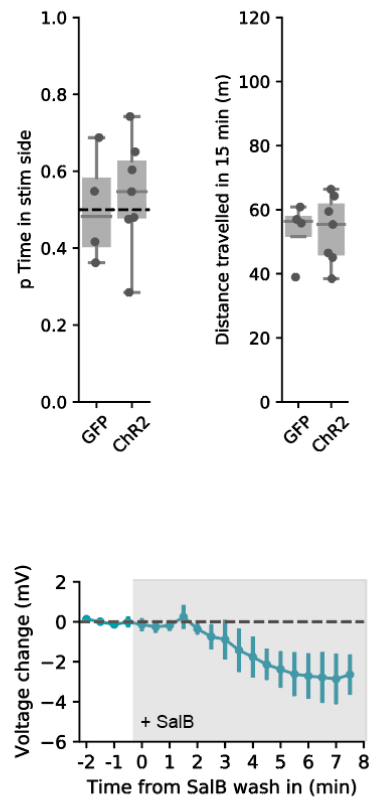

K

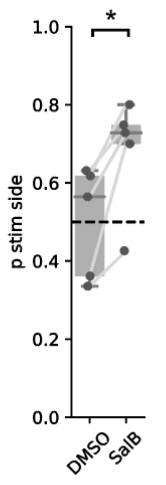


bioRxiv preprint doi: https://doi.org/10.1101/2021.03 08.434367; this version posted March 8, 2021. The copyright holder for this preprint (which was not certified by peer review) is the author/funder, who has granted bioRxiv a license to display the preprint in perpetuity. It is made available under aCC-BY-NC-ND 4.0 International license.

Figure 7 | Excitatory BA input supports real time place preference only after inhibition of $\mathrm{vH}^{\mathrm{BA}}$ neurons.

A. Schematic of experiment. GFP or excitation-specific CaMKii ChR2 were expressed in BA, and an optic fibre implanted in vH.

B. Real time place preference (RTPP) assay. One side of a chamber was paired with $20 \mathrm{~Hz}$ blue light stimulation. Example trajectories of GFP (left) and ChR2 (right) expressing animals over the 15 min RTPP session. Note lack of preference for light-paired $(\mathrm{stim})$ side in either group. Scale bar $=15 \mathrm{~cm}$

C. Summary of RTPP. Left, Proportion of time spent on stim side (left) and total distance travelled (right) in GFP and ChR2 animals. Note lack of preference for stim side in either condition.

D. Strategy to express $\mathrm{KORD}$ in $\mathrm{vH}^{\mathrm{BA}}$ neurons.

E,F. Bath application of SalB $(100 \mathrm{~nm})$ hyperpolarises KORD expressing $\mathrm{vH}^{\mathrm{BA}}$ neurons, and reduces AP firing. See Figure S4 for full quantification. Scale bar $=30 \mathrm{mV}, 100 \mathrm{~ms}$.

G. Schematic of strategy to inhibit $\mathrm{vH}^{\mathrm{BA}}$ neurons during $\mathrm{BA}$ input driven $\mathrm{RTPP}$.

H,I. As B,C but comparing the effect of either DMSO (vehicle) or SalB (KORD agonist) injections 15 mins before testing in control mice. Note lack of RTPP in both conditions indicating no effect of SalB in control mice.

$\mathbf{J , K}$. As $\mathbf{H}, \mathbf{l}$, but in mice expressing KORD in $\mathrm{vH}^{\mathrm{BA}}$ neurons. Note induction of RTPP in SalB injected mice compared to controls. 
bioRxiv preprint doi: https://doi.org/10.1101/2021.03.08.434367; this version posted March 8, 2021. The copyright holder for this preprint (which was not certified by peer review) is the author/funder, who has granted bioRxiv a license to display the preprint in perpetuity. It is made available under aCC-BY-NC-ND 4.0 International license.

A

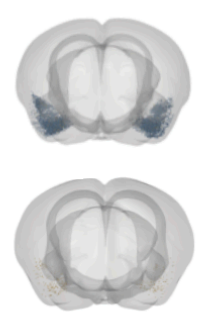

B

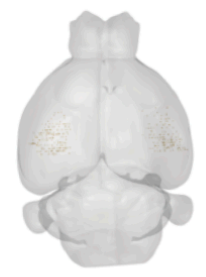

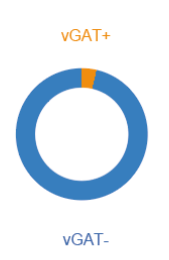

C

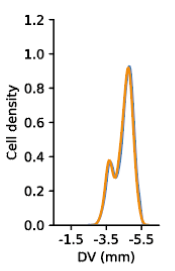

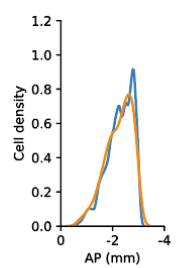

D

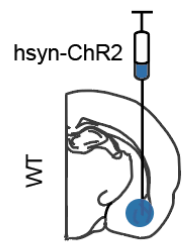

E

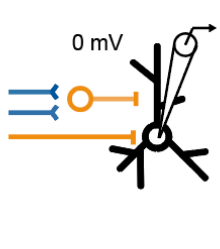

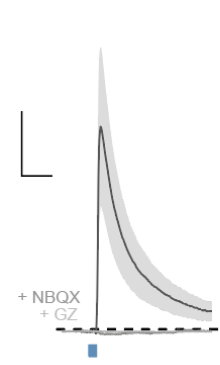

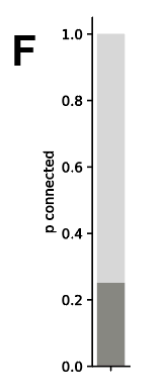

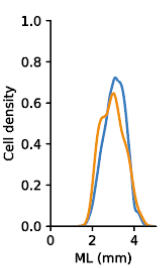

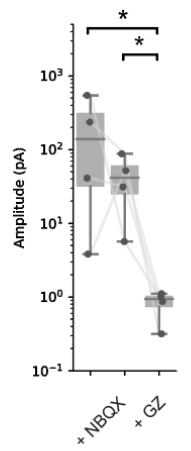

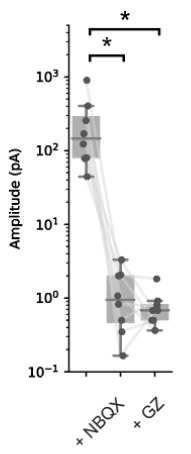

Figure S1 | Feedforward and direct inhibitory input from BA to vH

A. Whole brain distribution of labelled excitatory (blue) and inhibitory (orange) BA neurons after injection of CTX $\beta$ into vH.

B. Proportion of CTX $\beta$ labelled neurons that are vGAT+ (orange) and VGAT- (blue).

C. Distribution of CTX $\beta$ neurons that were vGAT+ (orange) and vGAT- (blue) across three anatomical axes. Note similar overall distribution.

D. Schematic of experiment. Pan neuronal synapsin promoter expresses ChR2 in both inhibitory and excitatory neurons, allowing assessment of feedforward and direct $\mathrm{BA}$ input to $\mathrm{vH}$.

E. Brief pulses of blue light evoked inhibitory currents at $0 \mathrm{mV}$. Average current traces pre and post NBQX and GZ. In a proportion of neurons (left) currents not completely blocked by the AMPA receptor antagonist NBQX, but removed by GABA receptor antagonist gabazine indicating presence of direct inhibition. In other recorded neurons, currents were completely blocked by NBQX (right), indicating only feedforward inhibition. Scale bar $=50 \mathrm{pA}, 10 \mathrm{~ms}$.

F. Left, proportion of neurons with inhibitory currents that received direct inhibition. Right, Amplitude before and after NBQX and GZ in two groups of neurons. Note log scale. 
bioRxiv preprint doi: https:/doi.org/10.1101/2021.03.08.434367; this version posted March 8, 2021. The copyright holder for this preprint (which was not certified by peer review) is the author/funder, who has granted bioRxiv a license to display the preprint in perpetuity. It is made available under aCC-BY-NC-ND 4.0 International license.

A<smiles>[Te]C1C2CC3CC(C2)CC1C3</smiles>
PFC
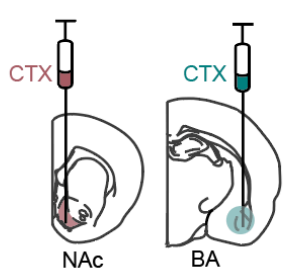

B

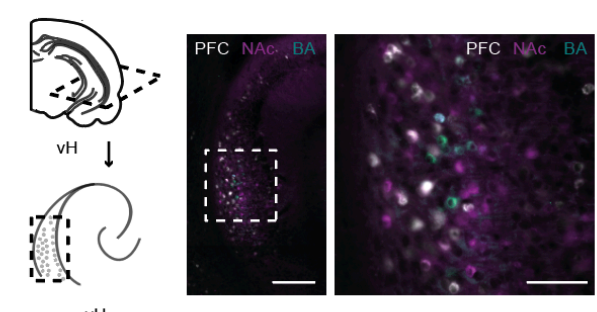

D

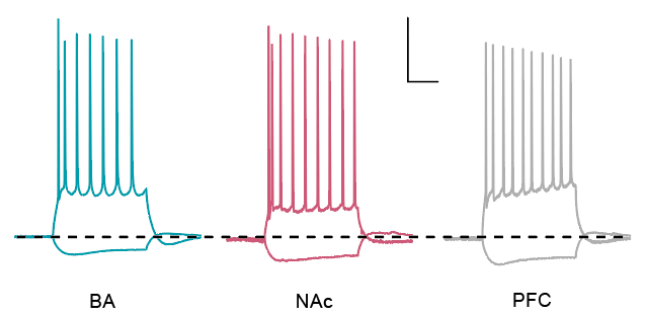

$\mathbf{F}$

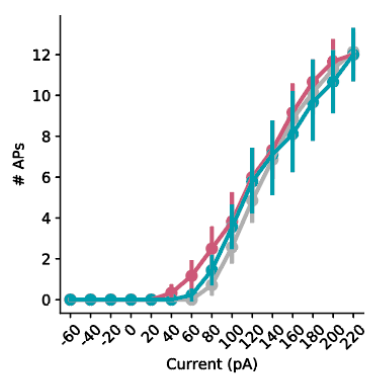

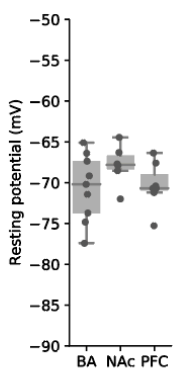

C

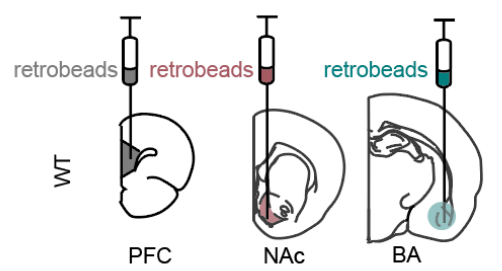

$\mathbf{E}$

\section{Figure S2 | Parallel output populations in vH.}

A. Schematic of experiment, three differently tagged CTX $\beta$ tracers were injected into PFC, NAC and BA.

B. horizontal section of $\mathrm{CA} 1$ / subiculum in $\mathrm{vH}$ showing interspersed but non overlapping labelling.

C. Strategy for electrophysiology recordings - projection populations were fluorescently labelled with retrobead injections into downstream projection areas.

D. Examples of positive $(+160 \mathrm{pA})$ and negative $(-40 \mathrm{pA})$ current steps in fluorescently targeted neurons from each population. Scale bar $=30 \mathrm{mV}, 100 \mathrm{~ms}$.

E,F. No large differences in input / output curve, resting potential, input resistance or sag amplitude across the three populations. 
bioRxiv preprint doi: https://doi.org/10.1101/2021.03.08.434367; this version posted March 8, 2021. The copyright holder for this preprint (which was not certified by peer review) is the author/funder, who has granted bioRxiv a license to display the preprint in perpetuity. It is made available under aCC-BY-NC-ND 4.0 International license.

A
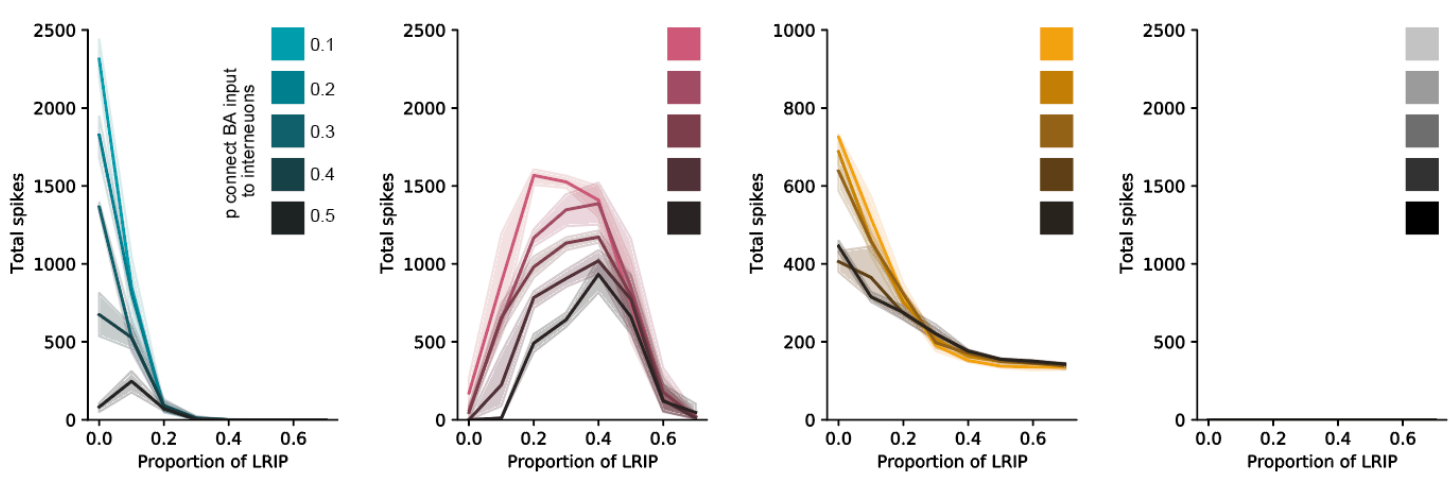

B
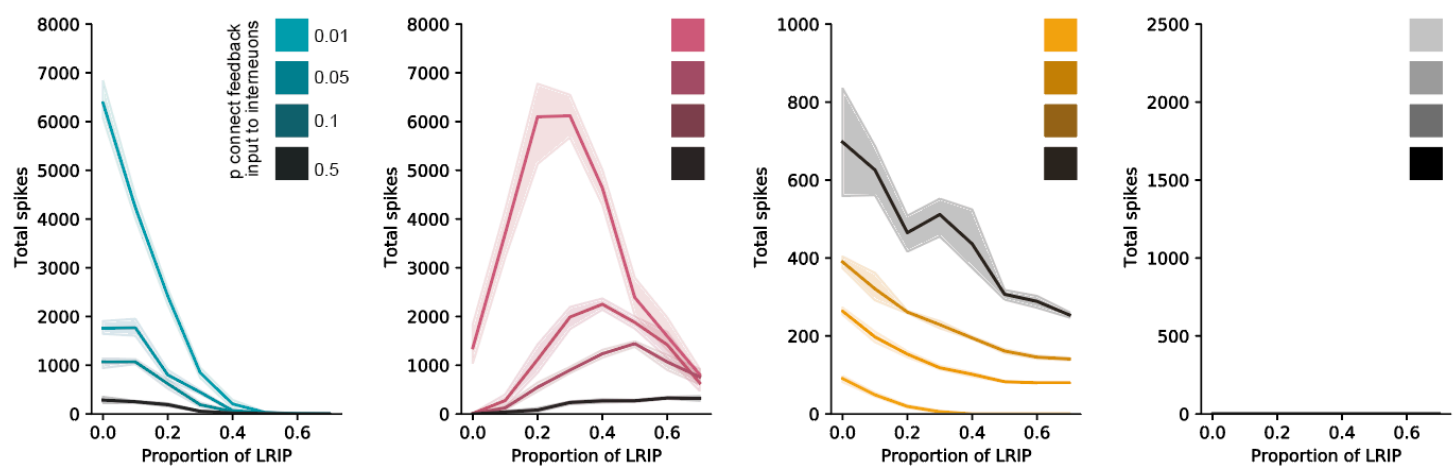

Figure $\mathrm{S} 3$ | The switch in $\mathrm{vH}^{\mathrm{BA}}$ and $\mathrm{vH}^{\mathrm{NAc}}$ activity is robust over a wide range of feedforward and feedback connectivity.

A. Total spiking of model in $\mathrm{vH}^{\mathrm{BA}}$ neurons (green), $\mathrm{vH}^{\mathrm{NAc}}$ neurons (red), $\mathrm{vH}^{\mathrm{PFC}}$ neurons (grey) and interneurons (orange) with increasing levels of BA inhibition, with different levels in feedforward inhibition (darker colours). Note that although absolute firing changes, the switch from $\mathrm{vH}^{\mathrm{BA}}$ to $\mathrm{vH}^{\mathrm{NAC}}$ activity with increasing inhibitory input is maintained.

B. As in (A) but for different levels of feedback connectivity. Note that again, the switch from $\mathrm{vH}^{\mathrm{BA}}$ to $\mathrm{vH}^{\mathrm{NAc}}$ with increasing inhibitory input is maintained 
bioRxiv preprint doi: https://doi.org/10.1101/2021.03 08.434367; this version posted March 8, 2021. The copyright holder for this preprint (which was not certified by peer review) is the author/funder, who has granted bioRxiv a license to display the preprint in perpetuity. It is made available under aCC-BY-NC-ND 4.0 International license.
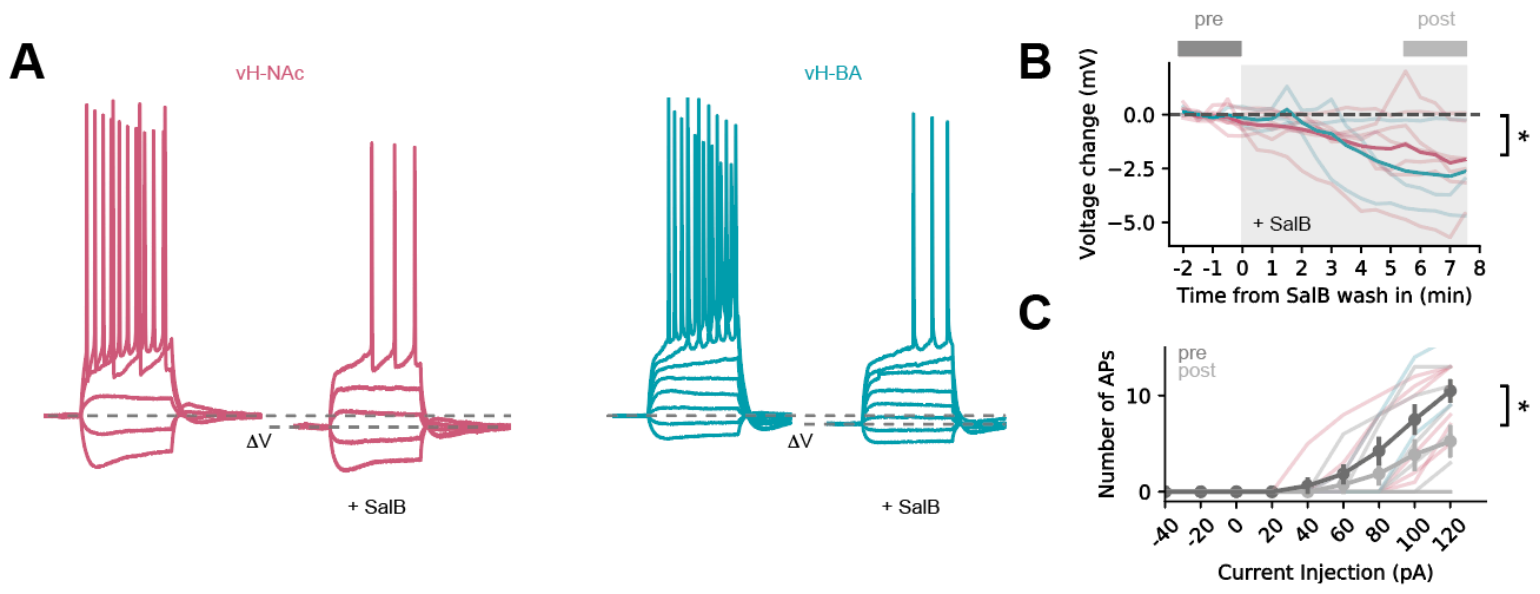

Figure S4 | SalB wash in reduces activity of KORD expressing neurons.

A. example traces before and after SalB wash in in $\mathrm{vH}^{\mathrm{NAc}}$ neuron (red) and $\mathrm{vH}^{\mathrm{BA}}$ neuron. Note lower resting potential and reduced spiking after SalB wash in.

B. Summary of effect of SalB wash in on resting potential for $\mathrm{vH}^{\mathrm{NAC}}$ neurons (red) and $\mathrm{vH}^{\mathrm{BA}}$ neurons. Thin lines are individual experiments, old line is group average.

C. Summary of effect of SalB wash in on current injection-induced action potential firing. Thin lines show individual vH ${ }^{\mathrm{NAc}}$ neurons (red) and vH-BA neurons, grey lines show group average. 
bioRxiv preprint doi: https://doi.org/10.1101/2021.03.08.434367; this version posted March 8, 2021. The copyright holder for this preprint (which was not certified by peer review) is the author/funder, who has granted bioRxiv a license to display the preprint in perpetuity. It is made available under aCC-BY-NC-ND 4.0 International license.

A

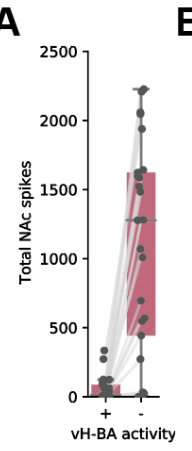

B

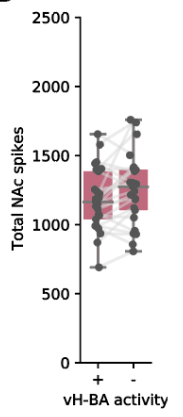

C

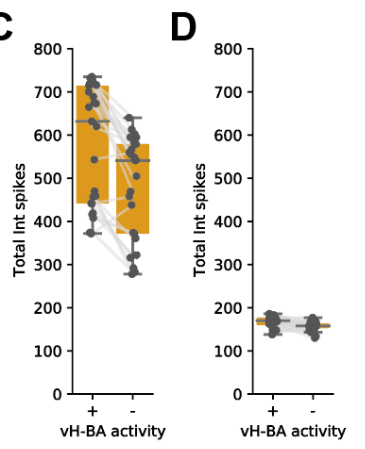

Figure S5 | Removing $\mathrm{vH}^{\mathrm{BA}}$ activity from the integrate of fire model increases $\mathrm{vH}^{\mathrm{NAc}}$ activity in response to excitatory but not excitatory and inhibitory BA input.

A. Total $\mathrm{vH}^{\mathrm{NAC}}$ activity with and without $\mathrm{vH}^{\mathrm{BA}}$ activity. Individual data points for all configurations of model presented in Figure $\mathrm{S} 3$. Note large increase in $\mathrm{vH}^{\mathrm{NAc}}$ activity on $\mathrm{vH}^{\mathrm{BA}}$ silencing across a wide range of feedback and feedforward connectivity.

B. As in (A) but with both excitatory and inhibitory input (inhibitory input scaled to $40 \%$ of excitatory input (as in example in Figure 5). $\mathrm{vH}^{\mathrm{BA}}$ silencing has no effect, as these neurons are already effectively silenced by BA inhibitory input.

C,D. As in $(\mathbf{A}, \mathbf{B})$ but for interneuron firing. $\mathrm{vH}-\mathrm{BA}$ silencing reduces interneuron firing, contributing to the increase in $\mathrm{vH}-\mathrm{NAc}$ activity. 
bioRxiv preprint doi: https://doi.org/10.1101/2021.03.08.434367; this version posted March 8, 2021. The copyright holder for this preprint (which was not certified by peer review) is the author/funder, who has granted bioRxiv a license to display the preprint in perpetuity. It is made available under aCC-BY-NC-ND 4.0 International license.

A

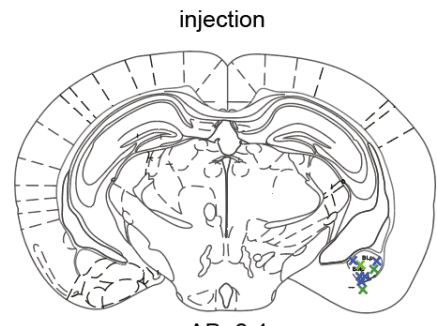

ChR2

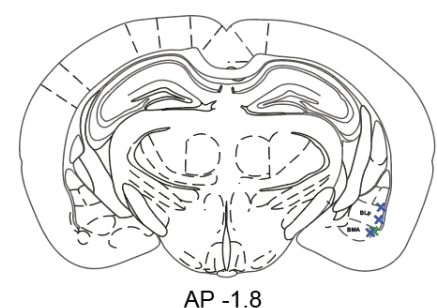

B

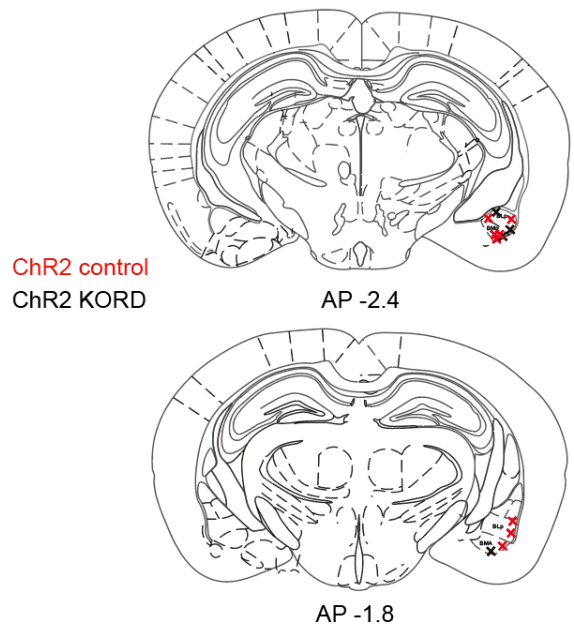

fibre placement

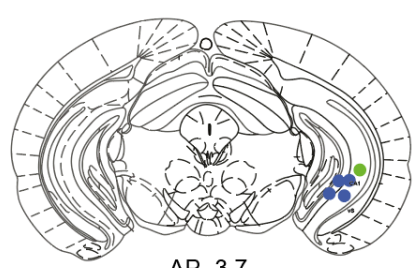

AP -3.7

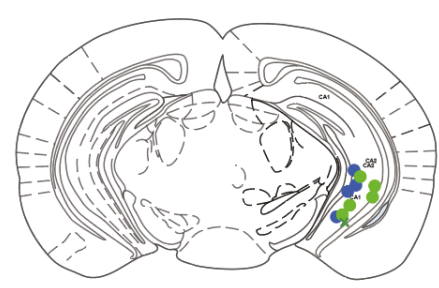

AP -3.1

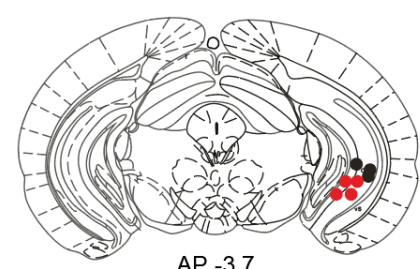

AP -3.7

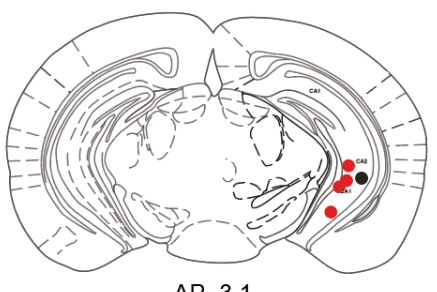

AP -3.1

Figure S6 | Histology for behavioural experiments in Figure 6.

A. Histology for experiments in Figure 6A-C

B. Histology for experiments in Figure 6G-K 
bioRxiv preprint doi: https://doi.org/10.1101/2021.03.08.434367; this version posted March 8, 2021. The copyright holder for this preprint (which was not certified by peer review) is the author/funder, who has granted bioRxiv a license to display the preprint in perpetuity. It is made available under aCC-BY-NC-ND 4.0 International license.

A

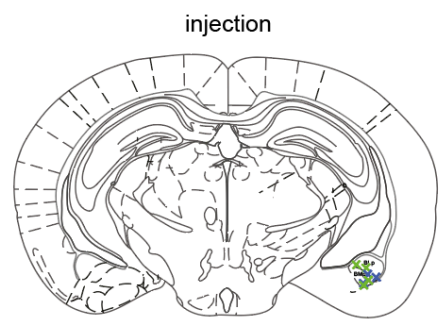

GFP
ChR2

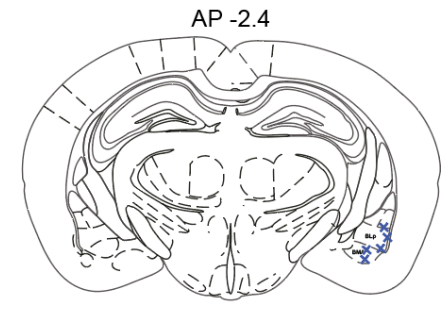

AP -1.8

B

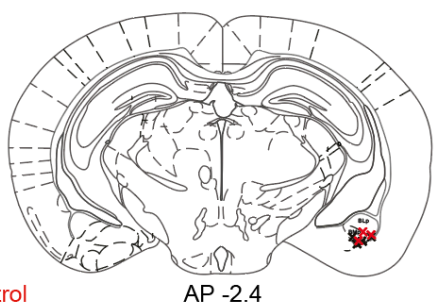

ChR2 control ChR2 KORD

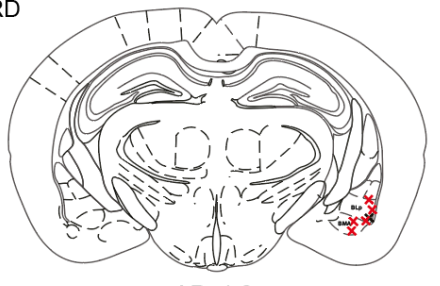

AP -1.8 fibre placement

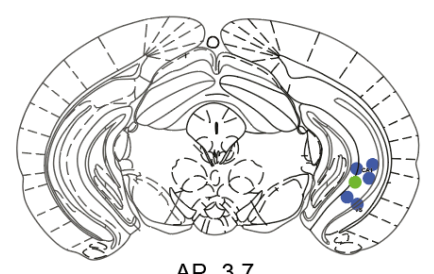

AP -3.7

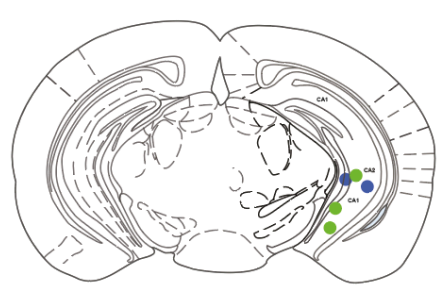

AP -3.1

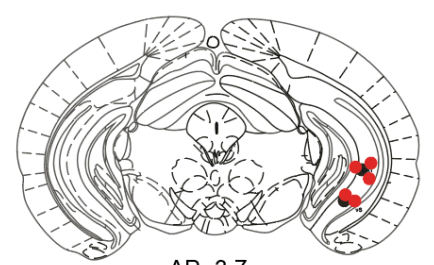

AP -3.7

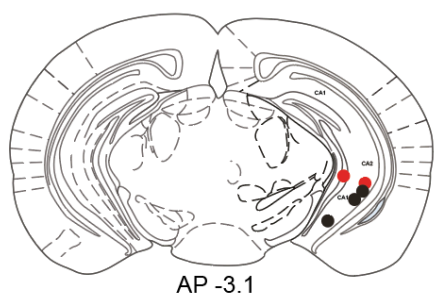

Figure S7| Histology for behavioural experiments in Figure 7.

A. Histology for experiments in Figure 7A-C

B. Histology for experiments in Figure 7G-K 
bioRxiv preprint doi: https://doi.org/10.1101/2021.03.08.434367; this version posted March 8, 2021. The copyright holder for this preprint (which was not certified by peer review) is the author/funder, who has granted bioRxiv a license to display the preprint in perpetuity. It is made available under aCC-BY-NC-ND 4.0 International license.

\section{STATISTICAL SUMMARY}

2

\begin{tabular}{|c|c|c|c|c|c|}
\hline Figure & Descriptors & $\mathbf{n}$ & Test used & Statistic & p-value \\
\hline $2 c$ & $\begin{array}{l}\text { Synapsin -70 mV } \\
\text { Amplitude (pA) } \\
\text { +/- NBQX }\end{array}$ & 9 & $\begin{array}{l}\text { Paired t-test } \\
\text { (log transformed data) }\end{array}$ & $t_{(8)}=10.04$ & 0.000008 \\
\hline $2 e$ & $\begin{array}{l}\text { Synapsin } 0 \mathrm{mV} \\
\text { Amplitude (pA) } \\
+/-\mathrm{GZ}\end{array}$ & 12 & $\begin{array}{l}\text { Paired t-test } \\
\text { (log transformed data) }\end{array}$ & $t_{(11)}=10.15$ & $6.35 \times 10^{-7}$ \\
\hline $2 g$ & $\begin{array}{l}\text { CaMKii } 0 \mathrm{mV} \\
\text { Amplitude (pA) } \\
\text { Baseline } \\
+\mathrm{NBQX} \\
+\mathrm{GZ}\end{array}$ & 3 & $\begin{array}{l}\text { Repeated-measures ANOVA } \\
\text { (log transformed data) } \\
\text { Tukey post hoc test } \\
\text { Baseline vs NBQX } \\
\text { Baseline vs GZ } \\
\text { NBQX vs GZ }\end{array}$ & $\begin{array}{l}\mathrm{F}_{(2,4)}=23.4 \\
\mathrm{t}_{(2)}=4.73 \\
\mathrm{t}_{(2)}=4.84 \\
\mathrm{t}_{(2)}=0.12\end{array}$ & $\begin{array}{l}0.006 \\
\\
0.001 \\
0.001 \\
0.9\end{array}$ \\
\hline $2 i$ & $\begin{array}{l}\text { vGAT } 0 \mathrm{mV} \\
\text { Amplitude (pA) } \\
\text { Baseline } \\
+\mathrm{NBQX} \\
+\mathrm{GZ}\end{array}$ & 6 & $\begin{array}{l}\text { Repeated-measures ANOVA } \\
\text { (log transformed data) } \\
\text { Tukey post hoc test } \\
\text { Baseline vs NBQX } \\
\text { Baseline vs GZ } \\
\text { NBQX vs GZ }\end{array}$ & $\begin{array}{l}\mathrm{F}_{(2,10)}=16.7 \\
\mathrm{t}_{(2)}=0.06 \\
\mathrm{t}_{(2)}=4.92 \\
\mathrm{t}_{(2)}=4.98\end{array}$ & $\begin{array}{l}0.0006 \\
0.9 \\
0.001 \\
0.001\end{array}$ \\
\hline $3 c$ & $\begin{array}{l}\text { BA:NAc -70 mV } \\
\text { Amplitude }(p A)\end{array}$ & 9 & Wilcoxon Rank Sum & $W=15$ & 0.43 \\
\hline $3 f$ & $\begin{array}{l}\text { BA:PFC -70 mV } \\
\text { Amplitude }(p A)\end{array}$ & 8 & Wilcoxon Rank Sum & $W=0$ & 0.0018 \\
\hline $3 i$ & $\begin{array}{l}\text { BA:NAc vGAT } 0 \mathrm{mV} \\
\text { Amplitude }(\mathrm{pA})\end{array}$ & 7 & Wilcoxon Rank Sum & $W=0$ & 0.016 \\
\hline 31 & $\begin{array}{l}\text { BA:PFC vGAT } 0 \mathrm{mV} \\
\text { Amplitude }(\mathrm{pA})\end{array}$ & 7 & Wilcoxon Rank Sum & $W=0$ & 0.016 \\
\hline $4 \mathrm{k}$ & $\begin{array}{l}\text { BA:NAc local vGAT } 0 \text { mV } \\
\text { Amplitude }(p A)\end{array}$ & 10 & Wilcoxon Rank Sum & $W=2$ & 0.006 \\
\hline $4 n$ & $\begin{array}{l}\text { BA:NAc CaMKii -70 mV } \\
\text { Amplitude }(p A)\end{array}$ & 10 & Wilcoxon Rank Sum & $W=22$ & 0.625 \\
\hline $4 p$ & $\begin{array}{l}\text { BA:NAc CaMKii } 0 \mathrm{mV} \\
\text { Amplitude }(\mathrm{pA})\end{array}$ & 10 & Wilcoxon Rank Sum & $W=3$ & 0.04 \\
\hline $6 c$ & $\begin{array}{l}\text { GFP vs ChR2 } \\
\text { p stimulated side }\end{array}$ & $\begin{array}{l}\text { GFP = } 6 \\
\text { ChR2 }=8\end{array}$ & t-test & $t_{(5.9)}=2.61$ & 0.041 \\
\hline $6 c$ & $\begin{array}{l}\text { GFP vs ChR2 } \\
\text { distance travelled }\end{array}$ & $\begin{array}{l}\text { GFP = } 6 \\
\text { ChR2 = } 8\end{array}$ & t-test & $t_{(9.2)}=1.27$ & 0.23 \\
\hline $6 f$ & $\begin{array}{l}\text { Voltage change in } \\
\text { SalB }(\mathrm{mV})\end{array}$ & 7 & $\begin{array}{l}\text { Repeated measures ANOVA } \\
\text { Effect of time }\end{array}$ & $F_{(24,144)}=5.94$ & $2.64 \times 10^{-12}$ \\
\hline $6 i-k$ & $\begin{array}{l}\text { DMSO vs SalB } \\
\text { Control vs KORD }\end{array}$ & $\begin{array}{l}\text { Cont }=7 \\
\text { KRD }=4\end{array}$ & $\begin{array}{l}\text { Mixed ANOVA } \\
\text { Effect of group } \\
\text { Effect of drug } \\
\text { Interaction }\end{array}$ & $\begin{array}{l}F_{(1,10)}=9.99 \\
F_{(1,10)}=10.6 \\
F_{(1,10)}=9.75\end{array}$ & $\begin{array}{l}0.010 \\
0.009 \\
0.010\end{array}$ \\
\hline
\end{tabular}


bioRxiv preprint doi: https//doi.org/10.1101/2021.03.08.434367; this version posted March 8, 2021. The copyright holder for this preprint (which was not certified by peer review) is the author/funder, who has granted bioRxiv a license to display the preprint in perpetuity. It is made available under aCC-BY-NC-ND 4.0 International license.

\begin{tabular}{|c|c|c|c|c|c|}
\hline $6 i$ & $\begin{array}{l}\text { DMSO vs SalB } \\
\text { p stimulated side }\end{array}$ & 8 & Paired t-test & $t_{(7)}=0.84$ & 0.43 \\
\hline $6 i$ & $\begin{array}{l}\text { DMSO vs SalB } \\
\text { distance travelled }\end{array}$ & 8 & Paired t-test & $\mathrm{t}_{(7)}=0.99$ & 0.35 \\
\hline $6 k$ & $\begin{array}{l}\text { DMSO vs SalB } \\
\text { p stimulated side }\end{array}$ & 4 & Paired t-test & $t_{(3)}=4.72$ & 0.018 \\
\hline $6 \mathrm{k}$ & $\begin{array}{l}\text { DMSO vs SalB } \\
\text { distance travelled }\end{array}$ & 4 & Paired t-test & $t_{(3)}=1.12$ & 0.34 \\
\hline $7 c$ & $\begin{array}{l}\text { GFP vs ChR2 } \\
\text { p stimulated side }\end{array}$ & $\begin{array}{l}\text { GFP }=4 \\
\text { ChR2 }=7\end{array}$ & t-test & $\mathrm{t}_{(6.4)}=0.40$ & 0.70 \\
\hline $7 c$ & $\begin{array}{l}\text { GFP vs ChR2 } \\
\text { distance travelled }\end{array}$ & $\begin{array}{l}\mathrm{GFP}=4 \\
\mathrm{ChR2}=8\end{array}$ & t-test & $\mathrm{t}_{(6.9)}=0.08$ & 0.94 \\
\hline $7 f$ & $\begin{array}{l}\text { Voltage change in } \\
\text { SalB }(\mathrm{mV})\end{array}$ & 3 & $\begin{array}{l}\text { Repeated measures ANOVA } \\
\text { Effect of time }\end{array}$ & $F_{(19,38)}=2.95$ & 0.002 \\
\hline $7 \mathrm{i}-\mathrm{k}$ & $\begin{array}{l}\text { DMSO vs SalB } \\
\text { Control vs KORD }\end{array}$ & $\begin{array}{r}\text { Cont }=7 \\
\text { KRD }=5\end{array}$ & $\begin{array}{l}\text { Mixed ANOVA } \\
\text { Effect of group } \\
\text { Effect of drug } \\
\text { Interaction }\end{array}$ & $\begin{array}{l}F_{(1,10)}=3.05 \\
F_{(1,10)}=8.96 \\
F_{(1,10)}=9.20\end{array}$ & $\begin{array}{l}0.11 \\
0.013 \\
0.013\end{array}$ \\
\hline $7 i$ & $\begin{array}{l}\text { DMSO vs SalB } \\
\text { p stimulated side }\end{array}$ & 7 & Paired t-test & $t_{(6)}=0.33$ & 0.75 \\
\hline $7 i$ & $\begin{array}{l}\text { DMSO vs SalB } \\
\text { distance travelled }\end{array}$ & 7 & Paired t-test & $\mathrm{t}_{(6)}=0.70$ & 0.51 \\
\hline $7 \mathrm{k}$ & $\begin{array}{l}\text { DMSO vs SalB } \\
\text { p stimulated side }\end{array}$ & 5 & Paired t-test & $\mathrm{t}_{(4)}=4.13$ & 0.014 \\
\hline $7 \mathrm{k}$ & $\begin{array}{l}\text { DMSO vs SalB } \\
\text { distance travelled }\end{array}$ & 5 & Paired t-test & $\mathrm{t}_{(4)}=2.77$ & 0.05 \\
\hline
\end{tabular}


bioRxiv preprint doi: https://doi.org/10.1101/2021.03.08.434367; this version posted March 8, 2021. The copyright holder for this preprint (which was not certified by peer review) is the author/funder, who has granted bioRxiv a license to display the preprint in perpetuity. It is made available under aCC-BY-NC-ND 4.0 International license.

\section{SUPPLEMENTARY STATSTICS SUMMARY}

2

\begin{tabular}{|c|c|c|c|c|c|}
\hline Figure & Descriptors & $n$ & Test used & Statistic & p-value \\
\hline S1f & $\begin{array}{l}\text { With direct inhibition } \\
\text { Amplitude }(\mathrm{pA}) \\
\text { Baseline } \\
+\mathrm{NBQX} \\
+\mathrm{GZ}\end{array}$ & 4 & $\begin{array}{l}\text { Repeated-measures ANOVA } \\
\text { (log transformed data) } \\
\text { Tukey post hoc test } \\
\text { Baseline vs NBQX } \\
\text { Baseline vs GZ } \\
\text { NBQX vs GZ }\end{array}$ & $\begin{array}{l}\mathrm{F}_{(2,6)}=7.9 \\
\mathrm{t}_{(3)}=0.7 \\
\mathrm{t}_{(3)}=4.7 \\
\mathrm{t}_{(3)}=3.5\end{array}$ & $\begin{array}{l}0.02 \\
\\
0.7 \\
0.001 \\
0.002\end{array}$ \\
\hline S1f & $\begin{array}{l}\text { No direct inhibition } \\
\text { Amplitude }(\mathrm{pA}) \\
\text { Baseline } \\
+\mathrm{NBQX} \\
+\mathrm{GZ}\end{array}$ & 8 & $\begin{array}{l}\text { Repeated-measures ANOVA } \\
\text { (log transformed data) } \\
\text { Tukey post hoc test } \\
\text { Baseline vs NBQX } \\
\text { Baseline vs GZ } \\
\text { NBQX vs GZ }\end{array}$ & $\begin{array}{l}\mathrm{F}_{(2,14)}=84.7 \\
\mathrm{t}_{(7)}=12.1 \\
\mathrm{t}_{(7)}=12.7 \\
\mathrm{t}_{(7)}=0.53\end{array}$ & $\begin{array}{l}1.5 \times 10^{-8} \\
\\
0.001 \\
0.001 \\
0.84\end{array}$ \\
\hline S2f & $\begin{array}{l}\text { Resting Potential (mV) } \\
\text { BA, NAc, PFC }\end{array}$ & $\begin{array}{l}\mathrm{BA}=9 \\
\mathrm{NAc}=7 \\
\mathrm{PFC}=7\end{array}$ & One-Way ANOVA & $F_{(2,19)}=1.38$ & 0.27 \\
\hline S2f & $\begin{array}{l}\text { Inpit Resistance (Ohms) } \\
\text { BA, NAc, PFC }\end{array}$ & $\begin{array}{l}\mathrm{BA}=9 \\
\mathrm{NAc}=7 \\
\mathrm{PFC}=7\end{array}$ & One-Way ANOVA & $F_{(2,19)}=1.77$ & 0.20 \\
\hline S2f & $\begin{array}{l}\text { Sag Amplitude (mV) } \\
\text { BA, NAc, PFC }\end{array}$ & $\begin{array}{l}\mathrm{BA}=9 \\
\mathrm{NAc}=7 \\
\mathrm{PFC}=7\end{array}$ & One-Way ANOVA & $F_{(2,19)}=1.40$ & 0.27 \\
\hline S4b & Pre vs post SalB & $\begin{array}{l}\mathrm{vH}-\mathrm{BA}=3 \\
\mathrm{vH}-\mathrm{NAc}=7\end{array}$ & $\begin{array}{l}\text { Mixed ANOVA } \\
\text { Effect of group } \\
\text { Effect of drug } \\
\text { Interaction }\end{array}$ & $\begin{array}{l}F_{(1,8)}=0.29 \\
F_{(1,8)}=13.8 \\
F_{(1,8)}=0.35\end{array}$ & $\begin{array}{l}0.6 \\
0.007 \\
0.57\end{array}$ \\
\hline S4c & Pre vs post SalB & $\begin{array}{l}\mathrm{vH}-\mathrm{BA}=2 \\
\mathrm{vH}-\mathrm{NAc}=6\end{array}$ & $\begin{array}{l}\text { Mixed ANOVA } \\
\text { Effect of group } \\
\text { Effect of drug } \\
\text { Interaction }\end{array}$ & $\begin{array}{l}F_{(1,6)}=0.21 \\
F_{(1,6)}=31.3 \\
F_{(1,6)}=0.75\end{array}$ & $\begin{array}{l}0.66 \\
0.001 \\
0.42\end{array}$ \\
\hline
\end{tabular}

